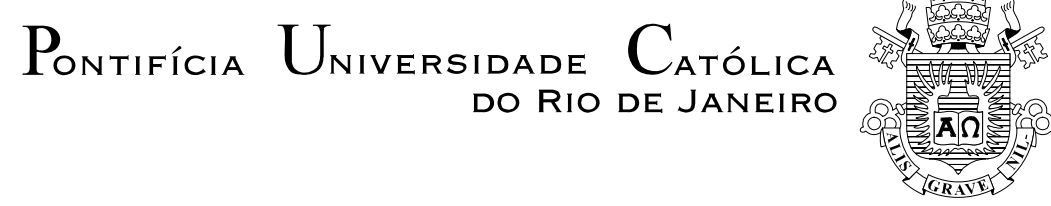

Zeneida Girão da Cunha

Há uma Jurisprudência Genuína no STF?

Um estudo de casos parecidos

Dissertação de Mestrado

Dissertação apresentada ao Programa de Pós-graduação em Direito da PUC-Rio como requisito parcial para obtenção do título de Mestre em Direito.

Orientador: Prof. Fábio Carvalho Leite 


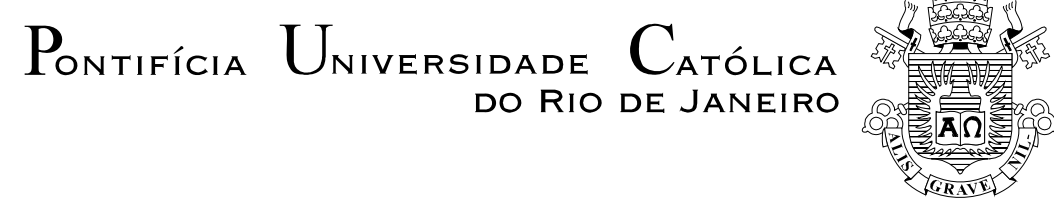

Zeneida Girão da Cunha

\title{
Há uma Jurisprudência Genuína no STF? \\ Um estudo de casos parecidos
}

\begin{abstract}
Dissertação apresentada ao Programa de Pós-graduação em Direito da PUC-Rio como requisito parcial para obtenção do título de Mestre em Direito. Aprovada pela Comissão Examinadora abaixo assinada.
\end{abstract}

\author{
Prof. Fábio Carvalho Leite \\ Orientador \\ Departamento de Direito - PUC-Rio
}

Prof. Noel Struchiner

Departamento de Direito - PUC-Rio

Prof. Rodrigo Brandão Viveiros Pessanha

Departamento de Direito-UERJ

Profa. Mônica Herz

Vice-Decana de Pós-Graduação do Centro de

Ciências Sociais - PUC-Rio

Rio de Janeiro, 16 de abril de 2014. 
Todos os direitos reservados. É proibida a reprodução total ou parcial do trabalho sem autorização da universidade, do autor e do orientador

Zeneida Girão da Cunha

Graduou-se em Direito pela Universidade Federal Fluminense (UFF). Ingressou no Mestrado em Direito na Pontifícia Universidade Católica em 2012 com o objetivo de dedicar também à carreira docente e à pesquisa.

Ficha Catalográfica

Cunha, Zeneida Girão da.

Há uma jurisprudência genuína no STF? Um estudo de casos parecidos / Zeneida Girão da Cunha ; orientador: Fábio Carvalho Leite - Rio de Janeiro: PUC-Rio, Departamento de Direito, 2014.

IX: $141 \mathrm{f}: 29,7 \mathrm{~cm}$

Dissertação (mestrado) - Pontifícia Universidade Católica do Rio de Janeiro. Departamento de Direito.

Inclui bibliografia

1. Direito - Teses. 2. STF. 3. Jurisprudência. 4. Precedentes. 5. Coerência Decisória. 6. Casos Parecidos 7. Autoprecedentes I. Leite, Fábio Carvalho. II. Pontifícia Universidade Católica do Rio de Janeiro. Departamento de Direito. III. Título. 


\section{Agradecimentos}

À CAPES, pelo suporte financeiro, sem o qual a realização do mestrado seria impossível.

À PUC- Rio, pelo corpo docente e estrutura oferecidos.

Ao Professor Orientador Fábio de Carvalho Leite e ao Professor Conrado Hübner Mendes, que através da dedicação às suas profissões, fizeram com que suas pesquisas instigassem a produção da presente dissertação.

Ao Professor Rodrigo Brandão Viveiros Pessanha, pelo excelente curso ministrado na Universidade Estadual do Rio de Janeiro (UERJ), pelo raciocínio crítico e por ter aceitado o convite para participar da presente banca.

Ao Professor Noel Struchiner, pelos ensinamentos durante o curso e pela participação na banca de mestrado.

Ao amigo Lucas Miotto Lopes, pela amizade e valiosos comentários.

Aos amigos Danilo dos Santos Almeida e Pedro Chrismann, pelas importantes sugestões.

Ao Anderson e à Carmen, profissionais excepcionais.

Aos meus padrinhos e pais, pela realização de mais um sonho.

À Helen Peixoto, Andrea Velloso e Patrícia Paiva, irmãs que a vida me deu.

À Bertha, que saudosamente vive em meu coração para todo o sempre.

A Deus, pelas conquistas dos últimos anos e a força que me faz continuar.

Ao Thiago, por tudo. 


\section{Resumo}

Cunha, Zeneida Girão da; Leite, Fábio Carvalho. Há uma jurisprudência genuína no STF? Um estudo de casos parecidos. Rio de Janeiro, 2014. 141 p. Dissertação de Mestrado - Departamento de Direito, Pontifícia Universidade Católica do Rio de Janeiro.

O escopo do trabalho é verificar e analisar possíveis incoerências no resultado das decisões e nas fundamentações dos ministros do Supremo Tribunal Federal. A partir de obras e artigos que indicam inexistir uma jurisprudência genuína no STF, elaborou-se uma pesquisa embasada nos informativos mais recentes do Supremo e em algumas decisões esparsas. O exame englobou decisões com trânsito em julgado em sede de controle difuso de constitucionalidade, controle concentrado de constitucionalidade e habeas corpus. Nos casos selecionados, observou-se que a Segunda Turma apresentou uma postura incoerente em casos parecidos, de desrespeito aos autoprecedentes, não sendo verificada a ocorrência de overruling, overriding, distinguishing ou transformation. Desse modo, a pesquisa aborda aspectos do processo decisório do Supremo, da deliberação entre os Ministros, dos votos e da estruturação das ementas dos acórdãos. Em vias de conclusão, apontam-se objeções ao perfil decisório do Supremo Tribunal Federal.

\section{Palavras-chave}

STF; Jurisprudência; Precedentes; Coerência decisória; Casos parecidos; Autoprecedentes. 


\section{Abstract}

Cunha, Zeneida Girão da; Leite, Fábio Carvalho (Advisor). Is there a genuine jurisprudence in the Supreme Court? A study of similar cases. Rio de Janeiro, 2014. 141 p. MSc. Dissertation - Departamento de Direito, Pontifícia Universidade Católica do Rio de Janeiro.

The scope of work is to identify and to analyze possible inconsistencies in the results of the decisions and the reasoning of the Federal Supreme Court. From books and articles that indicate inexistence of a genuine jurisprudence in the Supreme Court, a research was elaborated based on the latest newsletter from the Supreme and some sparse decisions. The examination encompassed decisions with res judicata in the seat of diffuse control of constitutionality, concentrated control of constitutionality and habeas corpus. In selected cases, it was observed that the Second Chamber showed an inconsistent approach in similar cases, disregarding self-precedents, with no occurrence of overruling, overriding, distinguishing or transformation. Thus, the research addresses aspects of the decision making process of the Supreme, the deliberation between the Justices, the votes and the structure of entry of judgment. Nearing conclusion, objections to the profile decision-making of the Supreme Court were raised.

\section{Keywords}

STF; Jurisprudence; Precedents; Decision consistency; Similar Cases; Self-precedents. 


\section{Sumário}

1. Introdução 12

1.2. Método e estrutura de abordagem 13

2. Análise de aspectos para se construir $\begin{array}{ll}\text { jurisprudência } & 19\end{array}$

2.1. Rompendo com as tradições do civil law e common law 19

2.2. Precedentes 22

2.2.1. Precedente, decisão judicial e jurisprudência 26

2.2.2. Analogia e precedentes judiciais 28

2.3. Técnicas de julgamento: overruling, overriding, distinguishing e transformation 30

2.4. Eficácia dos precedentes judiciais 32

2.5. Do Processo decisório 40

2.6. Cada cabeça, uma sentença 40

3. Relatório das decisões 45

3.1. Habeas corpus em casos de furto simples consumado 51

3.1.1. "Decisão A"- HC no 93.393/RS 52

3.1.2. "Decisão B"- HC n 97.007/SP 55

3.1.3. "Decisão C"- HC n 107.184/RS 58

3.1.4. "Decisão D"- HC n 109.870/RS 63

3.1.5. "Decisão E"- HC no 118.089/MG 68

3.2. Habeas corpus em casos de furto simples tentado 71

3.2.1. "Decisão F"- HC no 106.510/MG 72

3.2.2. "Decisão G"- HC n 108.872/RS 78

3.2.3. "Decisão H"- HC n 114.060/MG 81

3.2.4. "Decisão I"- HC no 113.782/RS 88 
$\begin{array}{ll}\text { 4. Análise das decisões } & 93\end{array}$

$\begin{array}{ll}\text { 4.1. Furto simples consumado } & 93\end{array}$

4.1.1. "Decisão A"- HC no 93.393/RS 93

4.1.2. "Decisão B"- HC no 97.007/SP 93

4.1.3. "Decisão C"- HC n 107.184/RS 95

4.1.4. "Decisão D"- HC n 109.870/RS 98

4.1.5. "Decisão E"- HC no 118.089/MG 100

4.2. Resumo da análise dos casos de furto simples consumado 102

4.3. Furto simples tentado 103

4.3.1. "Decisão F"- HC no 106.510/MG 103

4.3.2. "Decisão G"- HC n 108.872/RS 105

4.3.3. "Decisão H"- HC no 114.060/MG 107

4.3.4. "Decisão I"- HC n 113.782/RS 113

4.4. Resumo da análise dos casos de furto simples consumado 115

$\begin{array}{ll}\text { 5. Resultado da pesquisa } & 117\end{array}$

$\begin{array}{ll}\text { 6. Conclusão } & 122\end{array}$

7. Referências Bibliográficas 126

8. Sites Webs apresentados 132 


\section{Lista de tabelas e quadros}

\section{Tabelas}

Tabela 01- Tabela esquemática reincidência 49

Tabela 02- Estrutura do inteiro teor da "Decisão A" 54

Tabela 03- Quadro resumo dos votos da "Decisão A" 55

Tabela 04- Estrutura do inteiro teor da "Decisão B" 57

Tabela 05- Quadro resumo dos votos da “Decisão B" 57

Tabela 06- Estrutura do inteiro teor da "Decisão C" 61

Tabela 07- Quadro resumo dos votos da "Decisão C" 63

Tabela 08- Estrutura do inteiro teor da "Decisão D" 66

Tabela 09- Quadro resumo dos votos da “Decisão D" 67

Tabela 10- Estrutura do inteiro teor da "Decisão E" 70

Tabela 11- Quadro resumo dos votos da “Decisão E” 71

Tabela 12- Estrutura do inteiro teor da "Decisão F" 76

Tabela 13- Quadro resumo da "Decisão F" 77

Tabela 14- Estrutura do inteiro teor da "Decisão G" 80

Tabela 15- Quadro resumo da “Decisão G” 81

Tabela 16- Estrutura do inteiro teor da "Decisão H" 87

Tabela 17- Quadro resumo dos votos da "Decisão H" 88

Tabela 18- Estrutura do inteiro teor da "Decisão l" 91

Tabela 19- Quadro resumo dos votos da "Decisão I" 91 


\section{Quadros}

Quadro 01- Decisões furto simples consumado da Primeira Turma do STF

Quadro 02- Decisões furto simples tentado da Primeira Turma do STF

Quadro 03- Decisões furto simples consumado da

Segunda Turma do STF

Quadro 04- Decisões furto simples tentado da Segunda Turma do STF 
Que os vossos esforços desafiem as impossibilidades, lembrai-vos de que as grandes coisas do homem foram conquistadas do que parecia impossível.

Charles Chaplin 


\section{1}

\section{Introdução}

O presente trabalho surgiu a partir das leituras dos estudos do Professor Conrado Hübner Mendes que incitaram reflexões sobre o que tem ocorrido tanto no palco quanto nos bastidores do Supremo Tribunal Federal. Destacam-se algumas de suas considerações: inexistência de uma jurisprudência propriamente dita no Supremo, os ministros julgam de forma isolada não levando em consideração os argumentos dos demais colegas, os votos são prolixos e tentam impressionar mais pela erudição das palavras do que pelos seus próprios argumentos, além do fato de a Corte não ser detentora da última palavra, sendo necessária uma deliberação intra e interinstitucional ${ }^{1}$.

A instigação do tema se reforçou com o fato de Mendes não ter realizado qualquer tipo de investigação empírica. A partir de outros trabalhos ${ }^{2}$ que constatavam alguns desses "sintomas institucionais" aqui elencados, propôs-se uma pesquisa embasada na análise das decisões do Supremo com o objetivo de confirmar esse cenário.

A pesquisa se iniciou a partir da leitura dos informativos mais recentes do

\footnotetext{
${ }^{1}$ MENDES, Conrado Hübner. Direitos fundamentais, separação de poderes e deliberação. São Paulo: Saraiva, 2011.

${ }^{2}$ Ver: SILVA, Virgílio Afonso da. "O STF e o controle de constitucionalidade: deliberação, diálogo e razão pública", in Revista de Direito Administrativo 250, 2009, p. 197-227. SUNDFELD, Carlos Ari; Souza, Rodrigo Pagani. Accountability e Jurisprudência do STF: estudo empírico de variáveis institucionais e estrutura das decisões, in Jurisdição Constitucional no Brasil. São Paulo: Malheiros, 2012. RODRIGUEZ, José Rodrigo. Como Decidem as Cortes? Para uma Crítica do Direito (Brasileiro). Rio de Janeiro: Ed. FGV, 2013. VOJVODIC, Adriana, Cardoso, Evorah; Machado, Ana. "Escrevendo um romance, primeiro capítulo: precedentes e processo decisório no STF", in Revista Direito GV, $\mathrm{n}^{\mathrm{o}}$. 9, 2009, p. 21-44. Disponível em: http://www.scielo.br/scielo.php?pid=S1808-24322009000100002\&script=sci_arttext. Acesso em: 05 jan de 2013. KLAFKE, Guilherme Forma. Vícios no processo decisório do Supremo Tribunal Federal. Monografia apresentada à Escola de Formação da Sociedade Brasileira de Direito Público- SBDP, 2010.
} 
Supremo Tribunal Federal (n 573 a 732) com o intuito de verificar a hipótese de que não há uma jurisprudência genuína ${ }^{3}$ no STF.

Destaca-se que além dos informativos, outras decisões esparsas também foram utilizadas.

A partir de uma seleção dos habeas corpus que examinam a possibilidade de aplicação ou não do princípio da insignificância a pacientes reincidentes que cometeram furto, dividiu-se o exame em dois blocos: a) casos parecidos sobre furto simples consumado e b) casos parecidos sobre furto simples tentado.

Desse modo, a presente dissertação tem como objetivo analisar teorias que circundam o tema e aplicá-las à pesquisa empírica selecionada, verificando se podemos afirmar, de algum modo, se há ou não uma jurisprudência genuína no Supremo Tribunal Federal.

\section{2 \\ Método e estrutura de abordagem}

A proposta dessa dissertação é verificar incoerências no resultado de decisões e fundamentações dos ministros do Supremo Tribunal Federal. Considera-se "incoerência”, para efeitos deste trabalho as seguintes posturas: a) o desrespeito aos autoprecedentes ${ }^{4}$, sem que se verifique na decisão a ocorrência de overruling $^{5}$, overriding ${ }^{6}$, distinguishing ${ }^{7}$ ou transformation $^{8}$; b) afirmações por

\footnotetext{
${ }^{3}$ Por "genuína" entende-se a jurisprudência em sentido estrito, isto é, decisões harmônicas que guardam, entre si, uma identidade no resultado dos julgamentos. A espinha dorsal do trabalho será a análise de decisões do STF e a sua deferência ou não aos autoprecedentes.

${ }^{4}$ Defende-se o respeito aos autoprecedentes, ou seja, um juiz ou um ministro que tenha julgado um caso parecido anterior deve seguir a mesma postura, a fim de que se preserve a coerência em suas decisões.

${ }^{5} \mathrm{O}$ overruling ocorre quando há a revogação completa de um precedente, consequentemente, o magistrado que está julgando o presente caso, exporá o motivo pelo qual não vai seguir o antigo precedente. Segundo Didier Jr, Braga e Oliveira overruling é a técnica através da qual um precedente perde sua força vinculante e é substituído (overruled) por outro precedente. Ver: DIDIER Jr., Fredie; BRAGA, Paula Sarno; OLIVEIRA, Rafael. "Curso de Direito Processual Civil”. Vol. II. 8a ed. Salvador: JusPodivm, 2013, p. 456.

${ }^{6} \mathrm{O}$ overriding acontece quando um tribunal limita o âmbito de incidência de uma determinada doutrina, pois há o surgimento de nova regra que revoga, parcialmente, o precedente.

${ }^{7}$ Para Celso Albuquerque "o distinguishing só ocorre quando a regra fixada no precedente coloca
} 
parte de alguns julgadores que não demonstram consistência ${ }^{9}$ e c) ementas que não traduzem de modo fiel o caso em análise e suas considerações.

Assume-se que casos $\operatorname{parecidos}^{10}$ são aqueles que apresentam fatos semelhantes e que, prima facie, haveria boas razões para tratá-los de modo juridicamente equivalente. Uma consequência disso é que não há qualquer razão inicial para a mudança de opinião futura da corte que decide um caso semelhante.

Este trabalho teve como objeto inicial a análise de informativos do Supremo Tribunal Federal mais recentes $\left(n^{0} 573\right.$ a 732), que abrangem, respectivamente, os períodos de fevereiro de 2010 a dezembro de 2013. Além deles, para confirmar a hipótese proposta, recorreu-se também a decisões esparsas do STF desde o ano de $2009^{11}$. O exame englobava decisões com trânsito em julgado em sede de controle difuso de constitucionalidade, em sede de controle concentrado de constitucionalidade, ou seja, ações declaratórias de constitucionalidade (ADCs), ações diretas de inconstitucionalidade (ADIs), e arguições de descumprimento de preceito fundamental (ADPFs), além de habeas corpus $^{12}$. Optou-se por julgamentos do STF por ser o órgão de cúpula do poder judiciário brasileiro.

A pesquisa compara decisões que versam sobre casos semelhantes e as separou por órgão decisório: Primeira Turma, Segunda Turma e Plenário. Quando a matéria não havia sido levada até o Plenário do Supremo, analisavam-se

sob seu âmbito normativo o caso atual e, ainda, assim, o juiz decide contrariamente àquela regra". Ver: SILVA, Celso de Albuquerque. Do Efeito Vinculante- sua Legitimação e Aplicação. Rio de Janeiro: Lumen Juris, 2005, p. 247.

8 "Trata-se de hipótese em que a Corte não realiza o overruling, nem muito menos o distinguishing do caso sob julgamento para deixar de aplicar o precedente, mas em que faz a transformação ou a reconfiguração do precedente sem revogá-lo". MARINONI, Luiz Guilherme. Precedentes Obrigatórios. São Paulo: Ed. Revista dos Tribunais, 2010, p. 343.

${ }^{9} \mathrm{Um}$ exemplo que elucida essa postura é quando um Ministro afirma que há precedentes do Supremo Tribunal Federal que sustentam o seu voto. No entanto, há uma grande divergência com relação a esse caso perante o STF.

${ }^{10}$ A expressão "casos parecidos" será adotada como sinônimo de "casos semelhantes" na presente pesquisa.

${ }^{11} \mathrm{O}$ uso de decisões esparsas apenas ocorreu após a constatação da hipótese problema selecionada através dos informativos do Supremo. Por meio desses julgamentos dispersos estruturou-se uma análise qualitativa dos casos.

${ }^{12}$ A partir da seleção dos Habeas Corpus desconsideraram-se Recursos Ordinários em habeas corpus, agravos regimentais em habeas corpus, habeas corpus que não foram conhecidos e habeas corpus que estavam aguardando voto-vista. 
isoladamente as decisões da Primeira Turma e da Segunda Turma, na tentativa de fixar a posição das turmas sobre aquele assunto. Por outro lado, quando havia alguma decisão do Plenário sobre aquela determinada matéria, examinava-se se a decisão do Plenário era conforme ou não a uma das Turmas ou a ambas, ou se era contrário às mesmas. Nesse último caso, investigou-se se havia ocorrido uma hipótese de overruling, overriding, distinguishing ou transformation.

A partir desse exame preliminar, a primeira constatação foi com base em decisões em sede de habeas corpus tanto da Primeira quanto da Segunda Turma do STF, que tratavam da possibilidade ou não de aplicação do princípio da insignificância a pacientes reincidentes em crimes de furto ${ }^{13}{ }_{-}{ }^{14}$.

Em seguida, recorreu-se a uma pesquisa detalhada sobre a posição tanto da Primeira Turma quanto da Segunda Turma do STF com relação à aplicação do princípio da insignificância a pacientes reincidentes que foram processados por terem cometido o crime de furto simples tentado ou consumado, sem que haja a incidência de qualquer atenuante, qualificadora, privilegiadora, agravante (excetua-se apenas a reincidência), concurso de crimes ou concurso de pessoas ${ }^{15}$.

\footnotetext{
${ }^{13}$ Dentro do período proposto na pesquisa, constatou-se apenas esse caso. Não se pode afirmar que há apenas esse, pois o filtro temático foi proposto com base em decisões que eram publicadas em informativos do STF. Obviamente, há decisões que não são publicadas. Além disso, ressalta-se que há habeas corpus que tratam da possibilidade de aplicação ou não do princípio da insignificância a pacientes que tenham cometidos outros crimes, sem contar os casos em que há a incidência de concurso de crimes, concurso de pessoas, agravantes, atenuantes, qualificadoras e privilégios. Observa-se a existência de inúmeros outros casos. No entanto, optou-se por casos parecidos que apresentassem perante o Supremo Tribunal Federal um número razoável de decisões que viabilizassem uma pesquisa.

${ }^{14}$ Chegou-se a essa conclusão com base nos seguintes informativos e habeas corpus do Supremo Tribunal Federal: informativo $\mathrm{n}^{\circ} 610$ de novembro de $2010\left(\mathrm{HC} \mathrm{n}^{\circ} 101.998 / \mathrm{MG}^{14}\right.$, Primeira Turma), informativo $\mathrm{n}^{\circ} 620$ de março de 2011 ( $\mathrm{HC}^{\circ}$ 106.510/MG ${ }^{14}$, Segunda Turma), informativo $\mathrm{n}^{\circ} 657$ de março de $2012\left(\mathrm{HC} \mathrm{n}^{\circ} 108.969 / \mathrm{MG}^{14}\right.$, Primeira Turma) e informativo $\mathrm{n}^{\mathrm{o}} 667$ de maio de 2012 ( $\mathrm{HC} \mathrm{n}^{\circ} 109.870 / \mathrm{RS}^{14}$, Segunda Turma).

${ }^{15}$ Quando se trata da possibilidade ou não de aplicação do princípio da insignificância aos crimes de furto, deve-se atentar para algumas situações que já foram enfrentadas pelas turmas do STF em que o princípio da insignificância não é aplicado: a) quando o bem objeto de furto por mais que possa ser considerado de baixo valor monetário para parcela da população brasileira, não o é para a vítima do crime (BRASIL, STF, HC nº 115.707/MS, Rel. Min. Cármen Lúcia, Dje: 12.08.2013); b) caso em que a defesa do paciente impetra habeas corpus requerendo a aplicação do princípio da insignificância, no entanto, o objeto em questão não apresenta uma baixa expressão monetária, levando-se em consideração o salário mínimo vigente à época do fato (BRASIL, STF, $\mathrm{HC} \mathrm{n}^{\circ}$ 118028/MT, Rel. Min. Dias Toffoli, Dje: 17.12.2013); c) quando se impetra habeas corpus perante o Supremo Tribunal Federal, contudo há supressão de instância, pois o mesmo não foi apreciado pelo Superior Tribunal de Justiça (BRASIL, HC n 111.618/MG, Rel. Min. Cármen
} 
Para realizar essa análise, utilizou-se como ferramenta o site do Supremo Tribunal Federal na internet (www.stf.jus.br) ${ }^{16}$, menu "jurisprudência" e opção "pesquisa". Por meio da expressão "habeas corpus e (insignific\$ ou bagatela) e furto e reincid\$” pesquisou-se, individualmente, tanto acórdãos quanto decisões com repercussão geral julgados tanto pela Primeira quanto pela Segunda Turma do $\mathrm{STF}^{17}$. Destaca-se que o caractere " $\$$ " foi inserido, pois o mesmo possibilita a busca de acórdãos que fazem referência às palavras: insignificância, insignificante, reincidente, reincidência e reincidir.

Com relação aos habeas corpus selecionados que tratam de furto simples consumado e furto simples tentado, dos 55 (cinquenta e cinco) ${ }^{18}$ acórdãos da Primeira Turma do STF, 9 (nove) atendem aos requisitos dos casos de furto simples ${ }^{19}$, enquanto 5 (cinco) cumpriam as exigências dos casos de furto simples tentado $^{20}$.

Já com relação às decisões os da Segunda Turma, do total de 32 (trinta e dois) ${ }^{21}, 9$ (nove) atendem a objetivo proposto, sendo que 5 (cinco) de furto

Lúcia, Dje: 15.06.2012); d) quando o bem furtado não é considerado insignificante na seara do direito penal, no entanto, é considerado como sendo de baixa expressão econômica (BRASIL, STF, HC no 107.138/RS, Min. Rel. Ricardo Lewandowski, Dje: 30.05.2011). A presente análise desconsiderou qualquer caso que envolvesse uma dessas hipóteses.

${ }^{16} \mathrm{O}$ acesso ao site foi realizado em 30 de setembro de 2013.

${ }^{17}$ Destaca-se que a pesquisa não fixou o padrão de pesquisa como "habeas corpus e insignific\$ e furto e (simples ou tentado) e reincid\$, porque muitas vezes a ementa do acórdão não cita qual o crime que o paciente praticou, ou então, somente transcreve o artigo correspondente do Código Penal. Desse modo, optou-se por averiguar todos os habeas corpus, individualmente, para se ter certeza que ele se referia a furto simples ou furto tentado.

${ }^{18}$ Considerando-se a data de 26 de junho de 2014.

${ }^{19}$ BRASIL, STF, HC no 120.043/DF, Rel. Min. Luiz Fux. Dje: 03.12.2013; BRASIL, STF, HC n ${ }^{\circ}$ 111.611/MG, Rel. Min. Luiz Fux, Dje: 15.06.2012; BRASIL, STF, HC no 110.926/MG, Rel. Min. Dias Toffoli, Dje: 25.04.2012; BRASIL, STF, HC n ${ }^{\circ}$ 112.319/RS, Rel. Min. Dias Toffoli, Dje: 25.04.2012; BRASIL, STF, HC no 111.394/MG, Rel. Min. Cármen Lúcia, Dje: 16.10.2013; BRASIL, STF, HC n ${ }^{\circ}$ 108.969/MG, Rel. Min. Luiz Fux, Dje: 07.03.2012; BRASIL, STF, HC n ${ }^{\circ}$ 109.739/SP, Rel. Min. Cármen Lúcia, Dje: 13.12.2011; BRASIL, STF, HC no 98.917/RS, Rel. Min. Dias Toffoli, Dje: 16.05.2011 e BRASIL, STF, HC n ${ }^{\circ}$ 101.998/MG, Rel. Min. Dias Toffoli, Dje: 22.03.2011.

${ }^{20}$ BRASIL, STF, HC no 108.403/RS, Rel. Min. Luiz Fux, Dje: 05.02.2013; BRASIL, STF, HC n ${ }^{\circ}$ 111.124/RS, Rel. Min. Dias Toffoli, Dje: 21.08.2012; BRASIL, STF, HC n ${ }^{\circ}$ 107.674/MG, Rel. Min. Cármen Lúcia, Dje: 14.09.2011; BRASIL, STF, HC no 101.906/MG, Rel. Min. Dias Toffoli, Dje: 16.05.2011 e BRASIL, STF, HC n ${ }^{\circ}$ 101.591/MG, Rel. Min. Dias Toffoli, Dje: 04.05.2011.

${ }^{21}$ Considerando-se a data de 26 de junho de 2014. 
simples consumado ${ }^{22}$ e 4 (quatro) de furto simples tentado ${ }^{23}$. Os julgamentos realizados pela Primeira Turma foram sistematizados no "Quadro 01" (furto simples consumado) e "Quadro 02" (furto simples tentado), enquanto da Segunda Turma no "Quadro 03" (furto simples consumado) e "Quadro 04" (furto simples tentado).

Estruturou-se a pesquisa de forma a possibilitar uma linha de raciocínio que traçasse um perfil decisório de alguns ministros do Supremo Tribunal Federal e que também demonstrasse, de certo modo, alguma incoerência apresentada no processo deliberativo. Para isso, propõe-se o estudo de alguns problemas:

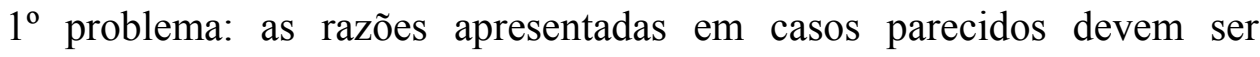
consideradas na formação de decisões de Cortes Supremas? Nesse caso, a análise será comparar os fundamentos apresentados nas decisões com os fundamentos apresentados nas decisões anteriores.

$2^{\circ}$ problema: as razões propostas pelos ministros em um processo devem ser levadas em consideração pelos outros ministros que estão decidindo? Por exemplo, imagine que em uma Turma há 5 (cinco) ministros "A", "B", "C", "D" e "E". "A" é o Relator e decide primeiro. "B" sabe dos fundamentos de "A". "B" tem que levar tais fundamentos em consideração, ou pode simplesmente ignorálos? E como deve ser a postura dos Ministros "C", "D" e "E"? Quais os reflexos que isso pode ter no voto final?

No Capítulo 2 e 3, será abordada a teoria que investiga esse problema, tratando assim, sobre aspectos do processo decisório, precedentes e jurisprudência. A análise das decisões tanto da Primeira quanto da Segunda Turma do STF é feita de forma qualitativa. No capítulo 4 da dissertação, estrutura-se um relatório de todos os habeas corpus que tratam dos casos de furto

\footnotetext{
${ }^{22}$ BRASIL, STF, HC n ${ }^{\circ}$ 118.089/MG, Rel. Min. Cármen Lúcia, Dje: 24.10.2013; BRASIL, STF, HC $\mathrm{n}^{\circ}$ 109.870/RS, Rel. Min. Joaquim Barbosa, Dje: 22.05.2012; BRASIL, STF, HC $\mathrm{n}^{\circ}$ 107.184/RS, Rel. Min. Gilmar Mendes, Dje: 21.11.2011; BRASIL, STF, HC n ${ }^{\circ}$ 97.007/SP, Rel. Min. Joaquim Barbosa, Dje: 02.03.2011; BRASIL, STF, HC no 93.393/RS, Rel. Min. Cezar Peluso, Dje: 15.05.2009.

${ }^{23}$ BRASIL, STF, $\mathrm{HC} \mathrm{n}^{\circ}$ 113.782/RS, Rel. Min. Ricardo Lewandowski, Dje: 17.06.2013; BRASIL, STF, HC no 114.060/MG, Rel. Min. Cármen Lúcia, Dje: 27.02.2013; BRASIL, STF, HC n 108.872/RS, Rel. Min. Gilmar Mendes, Dje: 23.09.2011; BRASIL, STF, HC nº 106.510/MG, Rel. Min Joaquim Barbosa, Dje: 13.06.2011.
} 
consumado como também dos casos de furto tentado. Após, decompõem-se os julgados, dividindo-os em dois blocos (decisões que versam sobre furto simples consumado e furto simples tentado), sendo averiguada a composição da banca, o qualificação do caso, as decisões anteriores, a estrutura do inteiro teor e o quadro resumo dos votos.

O capítulo 5 trata da análise das decisões. Nele, abordaram-se questões como: estrutura das ementas, diálogos entre os ministros, comparações entre as fundamentações das decisões em casos semelhantes decididos anteriormente, se houve voto de "mero acompanhamento" ${ }^{24}$, dentre outros. O capítulo 6 traça os resultados da pesquisa, enquanto o capítulo 7 aborda a conclusão do presente trabalho.

\footnotetext{
${ }^{24} \mathrm{O}$ voto de "mero acompanhamento" engloba os casos em que: a) há apenas a íntegra do voto do Ministro Relator, enquanto o resultado dos votos dos demais ministros são apenas registrados em ata; b) há apenas a transcrição no inteiro teor que um determinado ministro acompanhou o relator ou um ministro que proferiu o voto anteriormente.
} 


\section{2}

\section{Análise de aspectos para se construir jurisprudência}

\section{1 Rompendo com as tradições do civil law e common law}

A tradição jurídica do civil law não consegue prever de antemão todas as possíveis soluções para os casos que podem surgir em um litígio. Por mais detalhados e amplos que sejam os códigos, demonstram-se prolixos e, sendo algumas vezes, contraditórios. A grande quantidade de leis ${ }^{25}$ demonstra um anacrônico sistema jurídico que atrelado à falta de tradição de respeito aos precedentes, desencadeia em uma infinidade caótica de decisões judiciais.

$\mathrm{O}$ respeito aos precedentes tem origem no sistema do common law. Imagina-se que no civil law, a constituição, os códigos, leis ordinárias e outras normas jurídicas, teriam o condão de resolver os litígios jurídicos. É essa falsa ideia que dá ensejo ao desrespeito aos precedentes judiciais no sistema jurídico brasileiro. As praxes jurídicas de ambos os sistemas se fundam em posturas de segurança jurídica distintas, no civil law na sujeição do juiz à lei, e no common law no stare decisis, principalmente na ideia de se tratar casos iguais de modo igual (treat like cases like) ${ }^{26}$.

Diferenças entre os sistemas do common law e civil law, obviamente,

\footnotetext{
${ }^{25}$ Em meados do ano de 2007, o Brasil contava com 181.000 (cento e oitenta e uma mil) leis em vigor. Fonte: http://www.istoe.com.br/reportagens/3144_O+BRASIL+DAS+181+MIL+LEIS. Acesso em: 04.02.2014.

${ }^{26}$ Complementando: "Treat like cases alike é o princípio que sempre esteve na base do common law, da confiança e do respeito dispensados ao Poder Judiciário. Tratar da mesma forma casos similares é algo fundamental para a estabilidade do poder e para a manutenção da segurança necessária ao desenvolvimento das relações sociais". Ver: MARINONI, Luiz Guilherme. Op. cit., p. 109.
} 
existem. No entanto, a presente exposição abandona as peculiaridades do sistema jurídico herdado no Brasil ${ }^{27}$. Entende-se que a tradição jurídica do civil law não é o fator que justifica o uso dos precedentes e, consequentemente, uma análise dos mesmos.

A doutrina do stare decisis desenvolve uma sistemática de respeito aos precedentes, uma vez que ao se adotar essa postura, prestigia-se a segurança jurídica, coerência, estabilidade, previsibilidade das decisões, despersonalização das demandas, consistência, necessidade de legislar e replicabilidade ${ }^{28}$.

Por outro lado, um sistema jurídico que não respeita os precedentes, permite a produção de decisões judiciais contraditórias, o que fatalmente resultará em um aumento da litigiosidade e também do número de propositura das ações judiciais $^{29}$.

A emenda constitucional no 45 de 2004 (EC 45/2004) trouxe importantes mudanças na Constituição Federal, que em sua grande parte, afetaram as disposições referentes ao poder judiciário da carta constitucional. Dentre as mudanças, a referida emenda acrescentou o inciso LXXVIII ao art. $5^{\circ}$ da $\mathrm{CF}^{30}$ e o art. 103-A, $\mathrm{CF}^{31}$. Em ambos os artigos, observa-se a necessidade de se assegurar

\footnotetext{
${ }^{27}$ Propõe-se que por mais que tenhamos uma tradição da civil law, o respeito aos precedentes judiciais, de modo algum, prejudicaria a estrutura do modelo adotado no Brasil.

${ }^{28}$ Ver item 2.4. .

${ }^{29}$ Marinoni relata o caso Lawrence v. Texas, em que o Justice Kennedy teria afirmado que a "doutrina do stare decisis é essencial para o respeito devido aos julgamentos da Corte e para a estabilidade do direito". Ver: Lawrence v. Texas, 559 U.S. 558, 577, 2003. No Original: "The doctrine os stare decisis is essencial to the respect accorded to the judgments of the Court and the stability of the law". MARINONI, Luiz Guilherme. Op. cit., p. 77.

${ }^{30}$ Art. $5^{\circ}$, inc LXXVIII, CF: "a todos, no âmbito judicial e administrativo, são assegurados a razoável duração do processo e os meios que garantam a celeridade de sua tramitação".

31 "Art. 103-A, CF: O Supremo Tribunal Federal poderá, de ofício ou por provocação, mediante decisão de dois terços dos seus membros, após reiteradas decisões sobre matéria constitucional, aprovar súmula que, a partir de sua publicação na imprensa oficial, terá efeito vinculante em relação aos demais órgãos do Poder Judiciário e à administração pública direta e indireta, nas esferas federal, estadual e municipal, bem como proceder à sua revisão ou cancelamento, na forma estabelecida em lei.§ $1^{\circ}$ A súmula terá por objetivo a validade, a interpretação e a eficácia de normas determinadas, acerca das quais haja controvérsia atual entre órgãos judiciários ou entre esses e a administração pública que acarrete grave insegurança jurídica e relevante multiplicação de processos sobre questão idêntica. $\S 2^{\circ}$ Sem prejuízo do que vier a ser estabelecido em lei, a aprovação, revisão ou cancelamento de súmula poderá ser provocada por aqueles que podem propor a ação direta de inconstitucionalidade. $\S 3^{\circ}$ Do ato administrativo ou decisão judicial que contrariar a súmula aplicável ou que indevidamente a aplicar, caberá reclamação ao Supremo Tribunal Federal que, julgando-a
} 
um trâmite processual célere, e neste aspecto, a súmula vinculante é um dos instrumentos pelos quais se pode solucionar a questão da multiplicação de processos que versam sobre questões idênticas. No próprio corpo do texto do art. 103-A da CF, o legislador disciplina que a decisão teria efeito vinculante para os demais órgãos do Poder Judiciário e, também, para a administração pública direta e indireta, seja nas esferas federal, estadual e municipal.

Primeiramente, as súmulas foram criadas e ingressaram no sistema jurídico brasileiro como um mecanismo de facilitação da resolução de questões judiciais que se repetem constantemente. De modo algum, elas tinham o ideal de alcançar a estabilidade na ordem jurídica, a igualdade e a previsibilidade das decisões. A inserção das súmulas ${ }^{32}{ }^{33}$ foi anterior à súmula vinculante, sendo que aquelas tinham como escopo tão somente desafogar o judiciário, sendo verdadeiras ferramentas simplificadoras na aplicação do direito. Antes da criação da súmula vinculante, não se projetava um mecanismo de coerência da ordem jurídica $^{34}$.

Por outro lado, as súmulas vinculantes compõem um instrumento revestido de eficácia normativa, que podem ser editadas, revisadas ou canceladas. Uma vez descumpridas, podem ser objeto de reclamação perante o STF. O art. 103-A, § $1^{\circ}$ da CF disciplina que "a súmula terá por objetivo a validade, a interpretação e a eficácia de normas determinadas, acerca das quais haja controvérsia atual entre órgãos judiciários ou entre esses e a administração pública que acarrete grave insegurança jurídica e relevante multiplicação de processos sobre questão idêntica".

Destaca-se que a presente pesquisa não defenderá o uso incondicional dos precedentes judiciais como a doutrina do stare decisis sustenta. A proposta é observar a forma pela qual os ministros do Supremo Tribunal Federal estão

procedente, anulará o ato administrativo ou cassará a decisão judicial reclamada, e determinará que outra seja proferida com ou sem a aplicação da súmula, conforme o caso."

${ }^{32}$ Com relação às súmulas do STF, estas foram criadas por meio de emenda ao Regimento da Suprema Corte, com publicação em 1963. Em 1964, as súmulas entraram em vigência por meio de 370 (trezentos e setenta) enunciados.

${ }^{33}$ Súmulas constituem enunciados genéricos e abstratos, sendo autênticos resumos que objetivam solucionar determinados casos. Para aplicá-la, deve-se buscar a sua origem.

${ }^{34}$ MARINONI, Luiz Guilherme. Op. cit., p. 480. 
julgando, sustentando argumentos a partir da necessidade de respeito aos autoprecedentes. Entende-se que para que haja uma coerência no julgamento de casos parecidos, é necessário que haja uma harmonia e deferência aos julgamentos anteriores.

\section{2 \\ Precedentes}

Inicialmente, esclarece-se que a presente pesquisa tratará do tema de precedentes sob o aspecto judicial ${ }^{35}$. Tem-se que precedente corresponde a algo que antecede, levando-se em conta fato ou circunstância ocorrida anteriormente e que possui natureza idêntica ou parecida. A teoria geral do direito pode nos auxiliar a construir uma estrutura a respeito do que seria a ideia de precedente. Não apenas isso, mas também o que consistiria a denominada mesma questão jurídica.

Ressalta-se que a ideia de vinculação ao precedente remonta à obrigação de seguir um precedente não porque o tribunal (ou o juiz) concorda com a decisão, mas mesmo quando os mesmos atores judiciais acham que ela foi emitida com base em um erro ${ }^{36-37}$. Ou seja, a expectativa é que o precedente seja utilizado até que haja sua superação (overruled).

Será que deste modo o stare decisis colaboraria para uma espécie de obediência passiva e pejorativa? Sabe-se que, por exemplo, a hierarquia sempre esteve presente em nosso cotidiano e nos tempos mais remotos, seja na

\footnotetext{
${ }^{35}$ No entanto, é importante ressaltar que os precedentes não estão presentes apenas no Direito, mas também, nas ações cotidianas. Como exemplo há o caso em que o pai autoriza a fillha de 13 anos a ir a um show. O filho mais novo espera que quando tenha a mesma idade, o pai seja coerente e tome a mesma decisão pautada com base na anterior, ou seja, deixe o filho ir a um show. Ver: ALEXANDER, Larry. "Constrained by Precedent," 63 Southern California Law Review 1, 1989, p. 167.

${ }^{36}$ SCHAUER, Frederick. Thinking Like a Lawyer. Cambridge: Harvard University Press, 2009, p. 41. Essa seria uma versão mais rigorosa do uso dos precedentes pelo common law.

${ }^{37}$ Frisa-se que a presente pesquisa não sustenta essa teoria. Os argumentos dessa pesquisa se restringirão à obrigação de vinculação aos autoprecedentes.
} 
estratificação social, na ordenação dos cargos de uma empresa, no funcionalismo público, dentre outros. Nesse contexto, seria inimaginável tratar cada caso como um caso exclusivo e único, até porque isto inviabilizaria a rotina de trabalho de um juiz ou de um tribunal, tendo em vista a grande demanda de casos a serem solucionados. Assim, tratar as coisas "como resolvidas" facilitaria a vida de um tribunal, uma vez que nossa capacidade de ação é limitada, de tal sorte, para que se possa fazer com qualidade algumas coisas, é necessário deixar certos problemas para outra ocasião ${ }^{38}$.

O stare decisis relaciona-se com a ideia de estabilidade, pois traduz algo profundo e duradouro sobre um sistema de tomada de decisões que, continuamente, serve aos valores da estabilidade, consistência, definição (settlement), demonstrando respeito ao passado, enquanto outras instituições do governo demonstram menor estabilidade e previsibilidade ${ }^{39}$. A doutrina do stare decisis prega que os casos anteriores decididos foram julgados de forma correta, estabelecendo que possa haver um distinguishing entre casos, mas sem que isso indique que a decisão anterior foi decidida de forma errada.

Como se define um liame entre situações fáticas não idênticas? Qual é o método para que um caso passado seja usado como precedente em relação a outro caso que está sendo examinado por um tribunal? Schauer diz que "um caso precedente é um precedente válido, e consequentemente, vinculante, para todos os outros casos futuros que incorram no âmbito da ratio decidendi do caso precedente" $" 40$.

\footnotetext{
${ }^{38}$ MARINONI, Luiz Guilherme. Op. cit., p. 43.

${ }^{39}$ SCHAUER, Frederick. Op. cit, p. 43-44. No original: "Stare decisis, in thus valuing settlement for settlement's sake and consistency for consistency's sake, serves a range of values all having something to do with stability. Stability is not all there is, of course, and even Brandeis recognized that just as it is sometimes more important that things be settled than that they be settled correctly, so too is it sometimes more important that things be settled correctly than that they be settled incorrectly or imperfectly just for the sake of settlement. Yet however important it is on occasion to be right, following the past without regard to its rightness is pivotal to how law operates. Stare decisis, far from being a silly appendage to a decision-making system whose principal aim is to make the right decision now, in fact reflects something deep and enduring about a decision-making system that often serves the values of stability, consistency, settlement, and respect for the past just as other branches of government and other decision-making systems remain more flexible, less stable, less predictable, and more focused on the future."

${ }^{40}$ Idem, p. 50. No original: “... precedent cases have justifications or rationales lying behind their
} 
Destaca-se que os casos presentes nunca serão exatamente iguais aos casos anteriores julgados. Assume-se que casos parecidos são aqueles que apresentam fatos semelhantes e que, prima facie, há razões para que sejam tratados de modo juridicamente equivalente. Desse modo, deve-se investigar se o caso presente possui semelhanças com os casos anteriores no tocante aos seus principais aspectos, para que haja um tratamento de paridade entre os mesmos ${ }^{41}{ }_{-}{ }^{4}$.

Deve-se perseguir o vínculo entre duas ocorrências fáticas que não apresentam identidades de aspecto. A partir disso, indagações iniciais são feitas para que se possa identificar a similaridade em situações fáticas que não são iguais. Por exemplo, pode-se imaginar que situações fáticas ligadas a um determinado ramo do direito seria um critério para se delimitar um precedente. Schauer menciona o famoso caso Donoghue $v$. Stevenson, em que a Sra. Donoghue estava em um café, em uma cidade da Escócia, quando o seu acompanhante pediu uma cerveja de gengibre $^{43}$ para ela. Quando a senhora já tinha bebido metade do copo, o garçom completou o seu copo e, neste momento, pedaços de um caramujo rolaram da garrafa opaca de cerveja para dentro do copo da Sra. Donoghue. O caramujo já se encontrava em decomposição o que causou um surto gástrico e mental nela. No caso, o fabricante da bebida foi o responsável pelo pagamento do dano ${ }^{44}$.

Há três meios de se entender os precedentes: a) como gerador de regras, b)

outcomes, and a precedent case is a good precedent, and thus binding, for all subsequent cases falling within the ratio decidendi of the precedent case."

${ }^{41}$ A teoria geral do direito estabelece critérios a partir de um raciocínio analógico que permitiria que a identificação de casos semelhantes. Noel Struchiner aponta que "a estrutura básica do raciocínio analógico, que deve ser exercido na aplicação dos precedentes, foi descrita por diversos autores", dentre eles: Cass Sunstein, Jefferson White e Douglas Walton. Ver: STRUCHINER, Noel. Uma Análise da Textura Aberta da Linguagem e sua Aplicação ao Direito. Dissertação de Mestrado. Departamento de Filosofia da Pontifícia Universidade Católica do Rio de Janeiro, Fevereiro de 2001, p. 29 e 30.

${ }^{42} \mathrm{O}$ raciocínio analógico constitui uma ferramenta na identificação de casos semelhantes. Inicialmente, o principal argumento a seu favor é a importância da replicabilidade. No entanto, o raciocínio analógico não é suficiente. Ver: MacCORMICK, Neil. Legal Reasoning and Legal Theory, Oxford: Oxford University Press, 1978, p. 187.

${ }^{43}$ No original, ginger beer. Ginger beer é uma bebida similar a Ginger Ale, que é um refrigerante muito consumido nos EUA, Canadá, Inglaterra e Japão, que é feito à base se gengibre. Ginger beer é uma bebida que apresenta um sabor mais forte de gengibre, com menos gás e é menos doce. Disponível em: <http://pt.wikipedia.org/wiki/Ginger_ale>. Acesso em: 20 de jun. de 2013.

${ }^{44}$ SCHAUER, Frederick. Op. cit., p. 46. 
como um aplicador de princípios subjacentes e c) como uma decisão que gera um equilíbrio de razões. Com relação aos precedentes que geram regras, entende-se que os tribunais estariam obrigados a aplicá-los. Aplicando esse raciocínio ao caso da Sra. Donoghue, tem-se que: i) bebida com caramujo em decomposição, gera ii) indenização por parte do fabricante. Nesse caso, criou-se uma regra para que o tribunal decida desse modo em casos parecidos futuros. Não só isso, essa noção faz com que os precedentes sejam tratados como estatutos que solucionariam questões jurídicas. É por meio dessa interpretação de precedente que se gerou a distinção entre os institutos da ratio decidendi e obiter dictum ${ }^{45}$.

Já os precedentes que são aplicadores de princípios subjacentes, ilustram princípios que são justificadores daquela decisão e futuramente poderão ser utilizados do mesmo modo. Com base no caso da Sra. Donoghue: o Tribunal decidiu que i) a bebida no caramujo em decomposição, gera ii) indenização por parte do fabricante. No caso, imagine que a decisão foi motivada com base nos princípio da vulnerabilidade ${ }^{46}$ e da garantia de adequação ${ }^{47}$, enquanto o quantum indenizatório foi fixado com base no princípio da razoabilidade ${ }^{48}$. Desse modo, casos futuros que contemplem casos de moluscos em bebidas podem se valer dos princípios subjacentes à decisão.

Trata-se o precedente como uma decisão que gera um equilíbrio de razões sendo representado pela justificação que leva o Tribunal a decidir casos parecidos do mesmo modo. A partir disso, consideram-se os fatores elencados pelo órgão

\footnotetext{
${ }^{45}$ LAMOND, Grant. "Precedent and Analogy in Legal Reasoning", The Stanford Encyclopedia of Philosophy (Fall 2008 Edition), Edward N. Zalta (ed.). Disponível em:

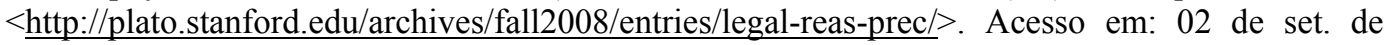
2013.

${ }^{46}$ Princípio decorrente das relações de consumo que dispõe que o consumidor é a parte mais fraca na relação consumerista, visto que não tem o controle sobre a cadeia de produção. Além disso, pode-se dizer que a vulnerabilidade comporta o marketing atrelado ao produto que obriga, em certa medida, o consumo do mesmo.

${ }^{47}$ Princípio elencado no art. $4^{\circ}$, II, "d" e V do Código de Defesa do Consumidor disciplina que o produto deve atender o binômio qualidade/segurança, considerando, assim, as regras técnicas e específicas de produção que dispõe a Política Nacional das Relações de Consumo.

${ }^{48} \mathrm{O}$ princípio da razoabilidade é utilizado como um meio para se auferir uma indenização razoável ao caso, contemplando a duração do sofrimento pela vítima, suas condições psicológicas, além de investigar quem é que produziu o dano e de que modo o ofensor o fez. Através desses vetores, calcula-se um dano moral que seja proporcional ao caso e que ao mesmo tempo não seja um meio pelo qual a vítima se enriqueça sem causa.
} 
julgador na decisão de um caso anterior para que se entenda o motivo pelo qual ele decidiu daquele modo. Em consequência, gera-se uma distinção natural para casos que não sejam parecidos ao caso anteriormente julgado ${ }^{49}$.

\subsection{1}

\section{Precedente, decisão judicial e jurisprudência}

Destaca-se que a decisão judicial e o precedente ${ }^{50}$ são institutos que não se confundem. Graficamente, pode-se imaginar um conjunto denominado "decisões judiciais", enquanto em seu interior há o subconjunto dos "precedentes judiciais". Desse modo, tem-se que todo precedente constitui uma decisão judicial, enquanto nem toda decisão será um precedente.

Entende-se por precedente as decisões judiciais que apresentam "potencialidade de se firmar como paradigma para a orientação dos jurisdicionados e magistrados $" 51 \_52$. Essa potencialidade seria a parte principal da decisão que servirá como parâmetro para julgamentos futuros.

A palavra precedente no dicionário ${ }^{53}$ significa: 1- antecedente, que precede; 2- fato ou circunstância, considerado em relação de anterioridade a outros de natureza igual ou semelhante. Se for levado em consideração esse significado, se alcançará um significado distorcido de precedente judicial. Precedente não é a primeira decisão que trata sobre algum assunto. Para uma

\footnotetext{
${ }^{49}$ LAMOND, Grant. "Precedent and Analogy in Legal Reasoning", The Stanford Encyclopedia of Philosophy (Fall 2008 Edition), Edward N. Zalta (ed.). Disponível em:

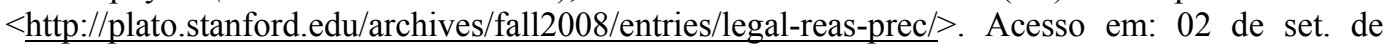
2013.

${ }^{50}$ Considera-se que o precedente judicial é fonte do Direito.

${ }_{51}^{51}$ MARINONI, Luiz Guilherme. Op. cit., p. 215.

${ }^{52}$ Geoffrey Marshall salienta que "o termo "precedente" em si tem uma série de aplicações. Em primeiro lugar, às vezes é aplicada sem maior reflexão ou análise de um conjunto de decisões anteriores supostamente relevantes (normalmente reunidos e citados pelo advogado de ambos os lados, em um caso de direito comum). Em segundo lugar, "precedente" pode ser usado como uma descrição do resultado ou um resultado de uma decisão em particular que se pensa ser de alguma importância. Em terceiro lugar, o termo pode ser usado para indicar um domínio mais vasto que a decisão em um caso particular é acusado de criar uma fundamentação ou esclarecimento.". Tradução livre. Op. cit., p. 503-504.

${ }^{53}$ Dicionário Michaelis (versão eletrônica: Dic Michaelis).
} 
decisão judicial ser um precedente, ela deve resolver os mais importantes argumentos relacionados à questão de direito. É viável que a primeira decisão que aborde um novo caso jurídico estabeleça um novo precedente, mas para isso é necessário que a partir dele se produza uma nova tese jurídica. Em muitos casos, o precedente só será construído a partir de várias decisões que consolidarão um entendimento ${ }^{54}$.

Observa-se que muitos operadores do Direito ${ }^{55}$ fazem o uso da expressão "precedente" de forma incorreta. Em muitos casos, em suas sustentações, referem-se a decisões que são favoráveis ao seu caso e afirmam que há precedentes que confirmam o seu pleito.

Dentro desse contexto, onde se enquadra a jurisprudência? Inicialmente, deve-se fazer a distinção entre jurisprudência em sentido amplo e em sentido estrito. Jurisprudência "latu sensu é a coletânea de decisões proferidas pelos juízes ou tribunais sobre uma determinada matéria jurídica" ${ }^{\$ 56}$. Esse conceito abarca tanto a jurisprudência uniforme quanto a contraditória. A primeira refere-se às decisões que concordam entre si, convergindo com a mesma tese jurídica quanto ao entendimento. A segunda compreende as decisões divergentes entre $\mathrm{si}^{57}$. Já a jurisprudência strictu sensu compreende um conjunto de decisões harmônicas dos tribunais. No caso, considera-se auctoritas rérum similiter judicatorum, ou seja, há identidade no critério de julgamento ${ }^{58}$.

A jurisprudência é formada a partir da reunião de decisões que possuem "uma linha essencial de continuidade e coerência. Para se falar em jurisprudência de um Tribunal é necessário certo número de decisões que coincidam quanto à

\footnotetext{
${ }^{54}$ MARINONI, Luiz Guilherme, op. cit., p. 216.

${ }^{55}$ Será observado que isso também ocorre com os Ministros do Supremo Tribunal Federal. A pesquisa irá demonstrar que muitos votos carecem de densidade argumentativa, tentando de algum modo, impressionar o leitor com o uso de vocabulários eruditos, uso de doutrina e afirmações contundentes, levando, assim, a entender que a questão já está pacificada. Ver Capítulo "6. Resultados da pesquisa".

${ }^{56}$ NADER, Paulo. Introdução ao Estudo do Direito. São Paulo: Ed. Forense. $13^{\text {a }}$ edição, 1996, p. 202.

${ }^{57}$ Idem, p. 202

58 Idem. Nader destaca que alguns autores entendem que "jurisprudência" compreenderia tão somente o seu sentido estrito. E ao fazê-lo, cometem erros ao afirmar que a jurisprudência apresenta dissonância, propondo, assim, mecanismos de uniformização.
} 
substância das questões objeto de seu pronunciamento"59.

Observa-se que muitas vezes, advogados e juízes usam a expressão jurisprudência sem compromisso com seu significado, querendo em muitos casos se referirem à existência de decisões de um determinado tribunal que não constituem jurisprudência.

A presente pesquisa questiona se no Supremo Tribunal Federal há uma jurisprudência genuína. E por genuína entende-se a jurisprudência em sentido estrito, isto é, decisões harmônicas que guardam, entre si, uma identidade no resultado dos julgamentos.

Nas decisões selecionadas, verificou-se em alguns julgados ${ }^{60}$, o uso indiscriminado da palavra "jurisprudência" pelos Ministros do STF e na própria ementa dos acórdãos. A pesquisa demonstra que no tocante à possibilidade de aplicação do princípio da insignificância a pacientes reincidentes que praticaram furto tentado ou consumado, não se pode afirmar que há jurisprudência do STF. Nesse caso, pode-se sustentar que há precedentes e jurisprudência apenas da Primeira Turma do $\mathrm{STF}^{61}$, enquanto na Segunda Turma haveria tão somente decisões judiciais que apresentam resultados incoerentes.

\subsection{2}

\section{Analogia e precedentes judiciais}

Os conceitos de analogia e precedente não devem ser confundidos. É comum muitos advogados se referirem a um caso julgado como um precedente, sendo que no caso em questão, o advogado apenas estaria se valendo deste como um método para analogia. O uso da analogia consiste na transmissão de informação de uma questão que ocorreu no passado para uma questão do presente. Deste modo, a questão "X" (fonte) transfere informações para questão "Y" (alvo),

\footnotetext{
${ }^{59}$ REALE, Miguel. Op. cit., p. 168.

${ }^{60} \mathrm{HC} \mathrm{n}^{\circ} 107.184 / \mathrm{RS}, \mathrm{HC} \mathrm{n}^{\circ} 118.089 / \mathrm{MG}, \mathrm{HC} \mathrm{n}^{\circ} 106.510 / \mathrm{MG}$ e $\mathrm{HC} \mathrm{n}^{\circ} 114.060 / \mathrm{MG}$.

${ }^{61}$ A Primeira Turma do STF entende que em o princípio da insignificância não se aplica em casos em que o réu é reincidente.
} 
pois em ambas, funções semelhantes e essenciais são encontradas entre as características dos fatos ${ }^{62}$. Assim, em busca da resolução da questão "Y", observase que há as soluções "X", "W" e "Z". No entanto, apenas a solução X é mais favorável ao argumento para que a parte adversária possa ser convencida. Nesse caso, a questão " $\mathrm{X}$ " será utilizada como fonte, pois esta se mostra útil ao argumento. Visualiza-se no exercício analógico uma verdadeira liberdade de escolha entre as soluções.

A analogia é utilizada quando um advogado tem, por exemplo, decisões favoráveis e contrárias ao caso que defende. Imagine que seu cliente quer ingressar com uma ação contra uma companhia aérea pleiteando danos materiais e morais, pois houve atraso de 1 (um) dia em seu voo em decorrência do mau tempo. O advogado observa que para a resolução da questão Y (atraso de voo e condições climáticas desfavoráveis) há as soluções X, W e Z. A solução X é favorável por completo, entendendo que são cabíveis tanto os danos materiais quanto os morais. Já a decisão $\mathrm{W}$ é favorável em parte, visto que só concede os danos materiais. E por fim, há a decisão $\mathrm{Z}$ que entende ser incabível qualquer tipo de dano ao autor. Certamente, o advogado do autor levará em consideração a solução X que se demonstra mais favorável à demanda.

Assim, não se pode confundir o instituto da analogia com o do precedente. O conceito jurídico de precedente é muito diferente. Um precedente obrigatório (leia-se: vinculante) possui uma natureza restritiva, já que o juiz possui pouco poder de escolha, pois aqui a decisão anterior se impõe para que outro resultado não seja eleito, mesmo que o juiz considere, em sua opinião, a decisão errada ou injusta, isto é, não há liberdade de escolha ${ }^{63}$. Já na analogia, utiliza-se uma determinada decisão que se demonstra favorável para que a mesma embase um

\footnotetext{
${ }^{62}$ SCHAUER, Frederick. Op. cit., p. 87.

${ }^{63}$ Frederick Schauer demonstra que com base no voto do caso United States ex rel. Fong Foo v. Shaughessy devemos entender que a noção de stare decisis se torna concreta quando um tribunal se sente obrigado a seguir uma decisão anterior, mesmo que considere essa decisão injusta. A intenção do stare decisis nunca foi a de que um tribunal apenas seguirá os precedentes que considerar corretos. No original:"Stare decisis has no bite when it means merely that court adheres to a precedent it considers correct. It is significant only when a court feels constrained to stick to a former ruling although the court has come to regard it as unwise or unjust." SCHAUER, Frederick. Op. cit., p.90
} 
$\operatorname{argumento}^{64}$. Por exemplo, a analogia seria um ótimo instrumento para um advogado produzir uma tese para sua defesa.

Em muitos casos, utiliza-se o termo "precedente" desprovido da propriedade e adequação que o termo nos propõe. Visualizam-se três possibilidades para o mesmo: a) o uso feito pelos advogados das partes quando se referem a decisões anteriores que possuem um parâmetro de correlação com o caso de seu cliente; b) em casos que despertam alguma paixão no debate jurídico e demonstram, de algum modo, que determinada decisão pode possuir alguma relevância; c) pode-se utilizar no estabelecimento de uma regra geral a partir de uma decisão que ilustra esse caso ${ }^{65}$.

Para se delinear a ideia de precedente, não se deve pensar apenas em fatos, mas em fatos relevantes. E é a partir das regras jurídicas, que um fato pode se tornar juridicamente relevante. ${ }^{66}$ Assim, em uma dada decisão, haverá fatos que possuem características juridicamente relevantes, enquanto outros serão juridicamente irrelevantes. Essas características relevantes que serão levadas em consideração na análise de casos futuros.

\section{3 \\ Técnicas de julgamento ${ }^{67}$ : overruling, overriding, distinguishing e transformation}

Essa seção não possui o objetivo de esgotar o tema, mas apenas traçar breves noções sobre as técnicas de julgamento que poderiam ter sido utilizadas pelos ministros nos votos dos habeas corpus selecionados, que poderiam justificar a postura incoerente de alguns ministros do STF.

Overruling ocorre quando há a revogação completa do precedente,

\footnotetext{
${ }^{64}$ SCHAUER, Frederick. Op. cit., p. 88.

${ }^{65}$ MARSHALL, Geofrey. What is binding in a precedent. What is Binding in a Precedent. In: MacCormick, Neil; SUMMERS, Robert S. Interpreting Precedents: a Comparative Study. London: Darmouth, 1997, p. 503.

${ }^{66}$ SCHAUER, Frederick. Op. cit.

${ }^{67}$ Ressalta-se que a doutrina classifica como técnicas de superação o overruling, overriding e transformation.
} 
havendo, assim, a perda da sua força vinculante e sua consequente substituição. ${ }^{68}$ O juiz exporá o motivo pelo qual não seguirá o antigo precedente, justificando com argumentos mais densos a razão que gerou a superação do precedente.

Nessa ótica, podem-se elencar alguns fatores que ensejariam essa ocorrência:

A transformação da concepção moral, política e de experiência é determinante de uma nova configuração do precedente. A alteração da concepção geral moral, assim como as novas proposições políticas, pertinentes à evolução do Estado, certamente podem abrir margem à revogação de precedentes. Do mesmo modo, incluída entre as proposições de experiência, as proposições relacionadas à evolução da tecnologia facilmente podem fazer ver a necessidade de overruling. ${ }^{69}$

Por outro lado, o overriding é um caso de revogação parcial do precedente. Supera-se de modo parcial o antigo precedente, pois há uma mudança no cenário jurídico a partir da inserção de uma regra ou princípio legal. Um exemplo de overriding praticado pelo STF ocorreu no Inquérito $687^{70}$ quando o Supremo entendeu que a Constituição Federal de 1988 não abarcava a tese da súmula 394 do $\mathrm{STF}^{71}$, devendo, desse modo, ser cancelada. O entendimento após agosto de 1999 foi no sentido da limitação da regra apenas aos que exerceram cargo ou função pública, para os quais seria, assim, concedido foro especial ${ }^{72}$.

Distinguishing ou distinguish é a distinção de casos realizada pelo juiz. Em consequência, não se utiliza um precedente anterior ao caso sob análise, pois este apresenta particularidades que obstam seu uso. Tucci estabelece que o distinguishing é um método "pelo qual o juiz verifica se o caso em julgamento pode ou não ser considerado análogo ao paradigma"73.

Por fim, a técnica do transformation ocorre quando o tribunal não aplica o precedente, sem fazer referência a essa mudança de postura, que consiste na

\footnotetext{
${ }^{68}$ DIDIER Jr., Fredie; BRAGA, Paula Sarno; OLIVEIRA, Rafael. "Curso de Direito Processual Civil”. Vol. II. $8^{\text {a }}$ ed. Salvador: JusPodivm, p. 456.

${ }^{69}$ MARINONI, Luiz Guilherme. Op. cit., p. 400.

${ }^{70}$ BRASIL, Supremo Tribunal Federal, Inq 687, Rel. Min. Sidney Sanches, Dj: 09.11.2001.

${ }^{71}$ Súmula 394 STF: Cometido o crime durante o exercício funcional, prevalece a competência especial por prerrogativa de função, ainda que o inquérito ou a ação penal sejam iniciados após a cessação daquele exercício (SÚMULA CANCELADA).

${ }^{72}$ SILVA, Celso de Albuquerque. Op. cit. p. 297.

${ }^{73}$ TUCCI, José Rogério Cruz e. Precedente Judicial como Fonte do Direito. São Paulo: Revista dos Tribunais, 2004, p. 174.
} 
superação implícita do entendimento. Transformation não se confunde com overruling, pois não há uma declaração expressa pela corte que houve superação do precedente.

\section{4 Eficácia dos precedentes judiciais}

Inicialmente, há uma distinção entre precedente vertical e precedente horizontal. Precedentes verticais remetem a uma ideia de obediência entre as instâncias da justiça. Por exemplo, um juiz singular deveria obedecer e acatar as decisões das instâncias superiores, no caso, um tribunal recursal ou da Suprema Corte. Já com relação aos precedentes horizontais seria o respeito e coerência às decisões tomadas pelo próprio tribunal, isto é, uma linha de raciocínio e continuidade às decisões proferidas por uma instituição judicial ${ }^{74}$.

A eficácia dos precedentes é uma ferramenta útil para se entender o grau de influência que os mesmos desempenham na análise de casos parecidos. Quanto à eficácia dos precedentes no ordenamento jurídico brasileiro, a doutrina classifica em: normativa, impositiva intermediária e meramente persuasiva ${ }^{75}$.

Precedentes com eficácia normativa são decisões que uma vez tomadas, devem ser seguidas em casos análogos, sofrendo o risco de cassação em caso de conflito nos julgamentos. Compreenderiam nesta categoria: decisões de controle concentrado de constitucionalidade proferidas pelo STF, súmulas vinculantes e as decisões proferidas pelos Tribunais de Justiça em controle concentrado de constitucionalidade tendo como parâmetro a constituição estadual ${ }^{76}$.

\footnotetext{
${ }^{74}$ Com base na doutrina do stare decisis, em latim, "ficar as coisas decididas", quando um órgão judicial produz um determinado precedente, isto criaria um vínculo com as decisões futuras deste mesmo órgão.

${ }^{75}$ A pesquisa utiliza a classificação de Patrícia Perrone Campos de Mello com algumas adaptações. Ver: MELLO, Patrícia Perrone Campos. Precedentes: o desenvolvimento judicial do direito no constitucionalismo contemporâneo. Rio de Janeiro: Renovar, 2008, p. 62.

${ }^{76}$ Enquadram-se também na categoria de precedentes normativos: "a) as decisões definitivas do STF que reconhecem a inconstitucionalidade de uma norma em caráter difuso, quando tiverem a sua execução suspensa por resolução do Senado Federal, nos termos do art. 52, X, CF; b) a
} 
Precedentes com eficácia impositiva intermediária, ou seja, aqueles que seriam utilizados "para além do caso julgado", compreendendo: a) decisões proferidas de modo incidental pelo plenário do STF e dos tribunais, no tocante à (in)constitucionalidade ${ }^{77}$; b) entendimentos que tratem de questões constitucionais fixadas em ações coletivas, em virtude dos limites subjetivos de suas conclusões; c) jurisprudência dominante ou sumulada do $\mathrm{STF}^{78}$.

Por fim, precedentes com eficácia meramente persuasiva compreendem a grande maioria das decisões presente na ordem jurídica, que tratam sobre matérias não constitucionais. Além disso, incluem-se as decisões proferidas pelos juízes de primeira instância e aquelas proferidas pelos órgãos fracionários dos tribunais, no que concerne à harmonia com as normas constitucionais ${ }^{79}$.

À primeira vista, pode-se imaginar que os casos elencados na presente pesquisa se enquadram na categoria de precedentes com eficácia meramente persuasiva, dado que eles servem como um meio de argumentação e persuasão dos juízes. No entanto, discorda-se da classificação exposta por Mello no tocante aos precedentes com eficácia meramente persuasiva. Afilia-se a Marinoni, pois para que um precedente possua eficácia persuasiva, deve ele, em alguma medida,

\footnotetext{
decisão incidental sobre a violação de princípio sensível, produzida em sede de ação direta interventiva, em caso de edição de decreto de intervenção que suspenda a execução do ato impugnado, com base no art. 36, § $3^{\circ}$, CF.” Ver: MELLO, Patrícia Perrone Campos. Op. cit., p. 106.

${ }^{77}$ Mello complementa que em tais situações há "a dispensa da reserva de plenário para aplicação do entendimento a casos idênticos (art. 481, parágrafo único, CPC)”. idem., p. 107.

78 Mello elucida que as situações enquadradas na eficácia impositiva intermediária "não se caracterizam como precedentes normativos. Elas não são dotadas de força vinculante e erga omnes idêntica àquela produzida por julgados do controle concentrado. Basta lembrar, por exemplo, que as decisões proferidas pelo pleno do STF em arguição incidental são rejeitadas pela Corte Constitucional como paradigma para fins de ajuizamento de reclamação por quem não tenha sido parte na ação (ao menos por enquanto). Entretanto, tais decisões não possuem tampouco eficácia meramente persuasiva, porque o ordenamento jurídico lhes confere efeitos para além do caso julgado. Assim, classificam-se como precedentes de eficácia impositiva intermediária. Vale reiterar, contudo, que o controle incidental encontra-se em processo de evolução e de aproximação do sistema concentrado, razão pela qual (...), se poderia mesmo afirmar que as decisões proferidas no âmbito do primeiro pelo pleno do STF se qualificam como julgados com eficácia impositiva intermediária a caminho da eficácia normativa. O mesmo ocorre com as decisões acerca da constitucionalidade das normas proferias pelo pleno dos tribunais em geral, no que respeita aos efeitos produzidos sobre seus próprios órgãos fracionários”. Ibidem, p. 107-108.

${ }^{79}$ Ibidem, p. 108.
} 
coagir o juiz ao seu uso, caso contrário ele não teria essa característica ${ }^{80}$. As razões sustentadas em um precedente não podem se apresentar apenas como um discurso que convencerá ou não o magistrado. Sublinha-se que:

Para que se tenha eficácia persuasiva é preciso que exista algum constrangimento sobre aquele que vai decidir. É necessário que o órgão decisório tenha alguma obrigação diante da decisão já tomada. O reflexo deste constrangimento ou desta obrigação apenas pode estar na fundamentação. A Corte obrigada não pode ignorar o precedente, devendo apresentar convincente fundamentação para não adotá-lo. Isso quer dizer que, no Brasil, os precedentes não vêm sequer sendo tidos como persuasivos. Embora constitua uma patologia, os tribunais e juízes muitas vezes não se julgam obrigados a respeitar os precedentes dos Tribunais Superiores. Em alguns casos, nem mesmo tomam em consideração os precedentes articulados pelos advogados das partes. Situação similar, e ainda mais preocupante, verifica-se quando se tem em consideração a relação do juiz e do tribunal com as suas próprias decisões. Similar porque também aí o juiz não respeita uma decisão judicial. No entanto, certamente se faz mais preocupante por tornar nítido o tratamento desigual a casos similares. Não há explicação para o mesmo órgão jurisdicional proferir decisões diferentes em casos similares. $O$ precedente, quando persuasivo, constitui um argumento da parte, e, por isso mesmo, não pode ser adotado ou rejeitado sem a devida fundamentação. Aliás, a desconsideração do precedente está, no mínimo, no mesmo plano do descaso em relação à prova, devendo gerar nulidade da decisão. ${ }^{81}$ (grifo nosso)

O que Marinoni explica é exatamente a espinha dorsal do presente trabalho, pois os habeas corpus selecionados demonstram que ministros de uma mesma Turma decidem de forma diferente em casos parecidos, ou seja, não respeitam seus autoprecedentes. A seleção de julgados aponta, claramente, que as decisões anteriores e os próprios votos emitidos pelos julgadores não apresentam densidade persuasiva e uma lógica conclusiva.

Há diversos trabalhos que defendem o uso irrestrito de precedentes, tentando adequar a realidade brasileira aos moldes da tradição do common law. O presente trabalho apenas propõe um estudo dos precedentes como vinculativos aos juízes e aos colegiados que já enfrentaram casos parecidos anteriormente, isto é, um respeito aos autoprecedentes.

Agir de forma diferente em casos parecidos gera insegurança e instabilidade para os jurisdicionados e para a sociedade como um todo. Soma-se a isso que uma atenção especial deve ser dada aos casos que envolvem direito

\footnotetext{
${ }^{80}$ MARINONI, Luiz Guilherme. Op. cit., p. 118.

${ }^{81}$ Idem, p. 118.
} 
penal, pois o que está em questão é a liberdade do indivíduo.

Argumentos com base na coerência, segurança jurídica, estabilidade, previsibilidade das decisões, despersonalização das demandas, consistência, replicabilidade e necessidade de legislar sustentam a proposta desta dissertação de respeito aos precedentes.

Qual argumento além da obediência aos precedentes pode embasar a necessidade de julgadores tomarem decisões de forma harmônica? A coerência. Com base em alguns apontamentos da teoria da coerência, reforça-se a discussão que julgar casos parecidos de modo diferente pode ser considerado um vício institucional.

A teoria da coerência possui três grandes defensores: Neil MacCormick com a teoria da coerência narrativa, Aleksander Peczenik com a teoria dos pesos e equilíbrio da coerência e Ronald Dworkin com a teoria da integridade. A abordagem mais interessante é a de MacCormick que afirma que uma "história é coerente quando há uma explicabilidade a partir de um único conjunto de princípios explicativos do tipo causal e motivacional" ${ }^{182}$.

Não há dúvidas de que a coerência jurídica pode ser prestigiada a partir da coerência deliberativa, uma vez que o raciocínio prático constitui parte importante do raciocínio probatório nos casos em que há o dever de condenar ou inocentar um indivíduo ${ }^{83}$. A coerência explicativa surge como uma ferramenta útil para os casos que são passíveis de grandes controvérsias.

No tocante à deliberação, considera-se que o raciocínio jurídico se enriquece quando tomadores de decisão buscam respostas sobre as proposições que não se tem certeza absoluta. Entre as virtudes importantes presentes na

\footnotetext{
${ }^{82}$ AMAYA, AMALIA. Legal Justification by Optimal Coherence. (Setembro de 2011). Ratio Juris, Vol. 24, Issue 3, pp. 304-329, 2011. Disponível em: $<$ http://papers.ssrn.com/sol3/papers.cfm?abstract_id=1908015>. Acesso em: 12 dez. 2013, p. 321.

${ }^{83}$ Amalia Amaya destaca quatro problemas do coerentismo do direito: a) Imprecisão: teorias da coerência do direito deixam a noção de coerência indefinida, vaga. b) Holismo: as teorias da coerência expõem versões sem restrições ao holismo. c) Circularidade e conservadorismoenvolvem uma circularidade viciosa. d) Qual inferência baseada na coerência?: as teorias da coerência são incompletas não especificando mecanismos legais com os quais julgadores atingem interpretações coerentes de leis ou fatos em um litígio. e) Por que coerência?: necessita-se perseguir a coerência, uma vez que muitas vezes é ignorada pela literatura, devendo ser um fator que deve ser estimado. (Idem, p. 311-313, tradução livre).
} 
composição da deliberação legal estão incluídas "a abertura a novas alternativas, prontidão para se considerar objeções à própria alternativa preferida e a capacidade de imaginar como as diferentes alternativas são suscetíveis de afetar as partes envolvidas $" 84$.

A coerência necessária para se condenar um indivíduo no âmbito civil é diferente da coerência utilizada para haver uma incriminação na seara penal. Percebe-se que há uma maior preocupação com os padrões de justificação quando os custos de um processo são vultuosos, nos casos mais graves de direito penal e, possivelmente, os que envolvem algum tipo de exposição midiática ${ }^{85}$

Fazendo oposição a argumentos que podem, em certa medida, entender que a coerência e a deliberação não são instrumentos úteis no processo decisório, sustenta-se que a coerência é parte integrante de um reconhecimento individual e político. Quando os juízes a desconsideram, eles se opõem a se autodeterminarem como indivíduos da sociedade política a que pertencem ${ }^{86}$.

Tomadores de decisões que respeitam os precedentes contribuem para a concepção da teoria do julgamento. A coerência atrelada às virtudes judiciais ${ }^{87}$ apresentara um modo de se observar os juízes não apenas como indivíduos éticos, mas sim, como profissionais componentes de um sistema fundamental na construção de uma "jurisprudência virtuosa" 88 .

A segurança jurídica, princípio fundamental insculpido na nossa Carta Constitucional $^{89}$, aliado a uma série de princípios que compõem a ordem jurídica,

\footnotetext{
${ }_{85}^{84}$ Ibidem, p. 316.

85 Ibidem.

${ }^{86}$ Ibidem, p. 323.

${ }^{87}$ Solum propõe que a virtude judicial abrangeria aspectos de: a) temperança judicial, b) coragem, c) temperamento judicial, d) inteligência judicial e e) sabedoria judicial. Ressalta-se que esta lista é meramente exemplificativa. (Tradução livre). Ver: SOLUM, Lawrence B., Virtue Jurisprudence: A Virtue-Ceantered Theory of Judging. Metaphilosophy, Vol. 34, No. 1/2, pp. 178-213, January 2003. Disponível em: <http://ssrn.com/abstract=369940 or http://dx.doi.org/10.2139/ssrn.369940>. Acesso em: 01 jan. 2014.

${ }^{88}$ Uma "jurisprudência virtuosa" afirma que uma teoria do julgamento pautada pela virtude é possível. Leva-se em consideração que a virtude explica e justifica suas práticas por meio da equidade. Ver: SOLUM, Lawrence B., Virtue Jurisprudence: A Virtue-Ceantered Theory of Judging. Metaphilosophy, Vol. 34, No. 1/2, pp. 178-213, January 2003. Disponível em: $<$ http://ssrn.com/abstract=369940 or http://dx.doi.org/10.2139/ssrn.369940>. Acesso em: 01 jan. 2014.

${ }^{89} \mathrm{O}$ art. $5^{\circ}$, caput, CF trata da segurança. Além deste, podemos citar outros incisos que,
} 
dão corpo à segurança e confiança dos cidadãos em um Estado de Direito.

Segurança jurídica e credibilidade no ordenamento jurídico compõem uma condicional, pois se há segurança jurídica, então haverá credibilidade dos cidadãos nesse ordenamento jurídico (se "p" então “q"). Nesse sentido, a transparência e a confiança dos jurisdicionados serão corolários deste processo.

Sabe-se que em um Estado de Direito, a desordem foi domesticada pela ordem jurídica. A estabilidade, dimensão objetiva da segurança jurídica, deve ganhar corpo através dos trabalhos dos juízes e tribunais, que constituem alicerces da prestação da tutela jurisdicional. Nesse sentido, Marinoni destaca que "não há, na prática dos tribunais brasileiros, qualquer preocupação com a estabilidade das decisões $(\ldots)$ há de se perceber o quanto antes que há um grave problema num direito variável de acordo com o caso" 90 .

No Brasil consagrou-se uma cultura aos recursos. Quando um cidadão procura um advogado, logo o indaga sobre o tempo que seu processo pode levar. Neste caso, o advogado pode com tamanha sinceridade responder: "se tivermos sorte, os juízes "X", "Y" e "Z" são favoráveis ao seu caso, enquanto "A", "B" e "C" não são. De modo que, na distribuição do seu processo, poderei the dar uma prévia".

Assim, juízes de primeira instância podem ser verdadeiros "números da sorte", podendo ou não resolver, inicialmente a lide de um indivíduo. Nesse sentido, observa-se que há uma verdadeira indústria de recursos instaurada no Brasil, impondo a passagem pela primeira instância como uma mera etapa burocrática e necessária para se chegar ao Tribunal de Justiça ou Tribunal Federal, STJ e $\operatorname{STF}^{91}$.

Além dos motivos expostos, destaca-se a necessidade de segurança jurídica e coerência por parte dos próprios juízes e tribunais, que em alguns casos julgam casos parecidos de forma diferente sem haver um motivo que determine

indiretamente, refletem o princípio da segurança jurídica. Ver art. $5^{\circ}$, incisos: XXXIX, XL, XLI, LIII, LIV e LV, CF.

${ }^{90}$ MARINONI, Luiz Guilherme. Op. cit., p. 122.

${ }^{91}$ Caso seja uma matéria trabalhista, inclui-se o TST (Tribunal Superior do Trabalho). 
essa postura.

A imensa gama de leis, estatutos, medidas provisórias não garantem a previsibilidade de todos os casos possíveis que podem chegar até o judiciário. Os países com tradição na civil law devem priorizar uma estabilidade que deve advir não do poder legislativo, mas sim, do poder judiciário, uma vez que ele é quem permitirá, através de uma previsibilidade nas suas próprias decisões, uma estabilidade, uma coerência, e consequentemente, a segurança jurídica.

Não se observa no direito brasileiro a missão que foi atribuída ao Supremo Tribunal Federal e ao Superior Tribunal de Justiça de uniformizar entendimentos, no tocante às leis federais e às normas constitucionais. Deste modo, é temeroso o comportamento de tais cortes e o descompromisso neste papel tão fundamental. ${ }^{92}$ Não só isso, mas também imaginar que um sistema que se baseia nas próprias leis (civil law) possa se comportar de modo completamente avesso à previsibilidade que as leis supõem gerar. Dentro deste panorama, "um ordenamento inidôneo a viabilizar a previsibilidade não pode ser qualificado como jurídico (...) a ideia de 'certeza do direito' visivelmente representa um componente indispensável da essência do próprio direito" ${ }^{93}$.

Casos parecidos que são julgados de formas diferentes geram insegurança, instabilidade e incredulidade das partes com relação ao sistema jurídico. Nesse aspecto, tratamentos diferenciados geram menor adesão à decisão pela parte vencida, fato este que afeta a credibilidade do Poder Judiciário.

A partir de um modelo de justiça virtuosa, deve-se considerar que a empatia (simpatia imparcial) do juiz pelas partes é um ingrediente necessário para uma boa decisão. Um bom juiz deve identificar e compreender o interesse das

\footnotetext{
${ }^{92}$ Ibidem,. p. 128. Complementando: “As decisões do Superior Tribunal de Justiça não são respeitadas no âmbito da Corte. As Turmas não guardam respeito pelas decisões das Seções e, o que é pior, entendem-se livres para decidir de forma desigual. Resultado disso, como não poderia ser diferente, é o completo descaso dos juízes de primeiro grau de jurisdição e dos Tribunais Estaduais e Regionais Federais em relação às decisões tomadas pelo Superior Tribunal de Justiça. Isso configura um atentado contra a essência do direito e contra a efetividade do sistema jurídico. Como é óbvio, também porque a segurança jurídica é direito fundamental e subprincípio concretizador do princípio do Estado de Direito, tais decisões não podem ser ignoradas, admitindose a sua fácil e constante alteração no âmbito da Corte e permitindo-se que os juízes de primeiro grau e tribunais ordinários possam livremente delas discordar ou nem sequer considerá-las."

${ }^{93}$ Ibidem, p. 127.
} 
partes, abandonando paixões e preferências pessoais ${ }^{94}$.

Efetiva-se a coerência quando se analisa decisões de casos parecidos e se diagnostica uma solidez no resultado das mesmas. Decisões que variam no resultado sem que ocorra overruling, overriding, distinguishing ou transformation são decisões inconsistentes.

Casos parecidos não suportam que juízes realizem julgamentos ad hoc, tratando os litigantes de modo diferenciado. Assim, "se um sistema legal é moralmente legítimo e tem autoridade sobre os particulares, então é inconsistente para uma pessoa a ser tratada de forma menos ou mais favorável pela lei do que outra pessoa cuja situação é legalmente indistinguível"95.

Por replicabilidade, entende-se que as decisões serão mais previsíveis quando houver um tratamento de paridade entre casos parecidos, ao invés de se considerar demandas repetidas no futuro como um julgamento novo. O precedente é uma boa ferramenta para a prática de tomada de decisões replicáveis, pois permite que menos erros sejam cometidos, uma vez que os juízes são indivíduos sujeitos a cometerem falhas ${ }^{96}$.

A incompletude da legislação faz com os precedentes possuam um importante papel no processo decisório. Visualiza-se que os precedentes podem servir como verdadeiros “estatutos". Para isso, é necessário que haja uma coerência no julgamento de casos parecidos.

Além disso, quando a legislação não apresenta uma resposta para a lide, como ocorre na presente pesquisa que aborda casos que envolvem o princípio da insignificância, os precedentes suprem, em grande parte, essa necessidade.

\footnotetext{
${ }^{94}$ SOLUM, Lawrence B. Op. cit., p. 197.

${ }^{95}$ LAMOND, Grant, "Precedent and Analogy in Legal Reasoning", The Stanford Encyclopedia of Philosophy (Fall 2008 Edition), Edward N. Zalta (ed.). Disponível em: $<$ http://plato.stanford.edu/archives/fall2008/entries/legal-reas-prec/>. Acesso em: 02 de set. de 2013.

${ }^{96}$ Idem.
} 


\section{5 \\ Do processo decisório}

O senso comum pode ser apresentado como uma ferramenta traiçoeira em qualquer ramo de estudo. Tal comportamento intuitivo poderia alicerçar o raciocínio que o órgão de cúpula do poder judiciário, no caso, o Supremo Tribunal Federal, consagra a sua própria jurisprudência.

Debruçando sobre esta mesma linha de raciocínio, poder-se-ia imaginar que a existência de súmulas vinculantes, de informativos semanais e o fato de o STF ser um órgão colegiado ${ }^{97}$ desenhariam um cenário de valorização e respeito à jurisprudência $^{98}$.

No entanto, estudos demonstram ${ }^{99}$ não só a pouca deferência a sua própria jurisprudência, mas também a deficiência embutida em seu método de decisão que o impede de construir razões compartilhadas pelos ministros no processo de tomada de decisão. Nesse sentido, Conrado Hübner Mendes alerta que "argumentos do tribunal quase nunca existem, exceto por obra de uma metáfora. Não há, exceções à parte, razões compartilhadas pela maioria dos ministros, razões que, boas ou ruins, pudéssemos generalizar como do tribunal"100.

\section{6 \\ Cada cabeça, uma sentença}

Casos que se localizam em uma "zona cinzenta" merecem uma atenção

\footnotetext{
97 Art. 101, CF.

${ }^{98} \mathrm{Na}$ última década construiu-se no cenário brasileiro a mentalidade de que o Supremo Tribunal Federal tem a última palavra questões de âmbito constitucional em geral. Essa mudança de "comportamento" pode ser constatada com um simples exemplo: na década de noventa, os manuais de direito constitucional não eram repletos de jurisprudência do STF e eram poucos os que falavam sobre o mesmo. Hoje isso não ocorre, pois as doutrinas atuais são repletas de jurisprudência do Supremo, e muitos deles o intitulam como o "guardião da constituição". Vide art. 102, caput, CRFB.

99 Tomou-se como base os estudos desenvolvidos por Carlos Ari Sundfeld (2013), Conrado Hübner Mendes (2011, 2013), José Rodrigo Rodriguez (2013), Adriana Vojvodic (2012, 2013) e Guilherme Forma Klafke (2010).

${ }^{100}$ MENDES, Conrado Hübner. Onze Ilhas. Disponível em: $<$ http://www.osconstitucionalistas.com.br/onze-ilhas >. Acessado em: 02/10/2012.
} 
especial por parte da Suprema Corte, prestigiando a deliberação e abandonando o "mero voto de acompanhamento". Desse modo, objetiva-se a construção de uma linha de raciocínio desprovida de incoerências ${ }^{101}$. O STF, muitas vezes, cria um monólogo a partir do voto do relator, enquanto alguns ministros se comportam como indivíduos surdos-mudos.

O STF demonstra que possui pouco apreço ao processo de deliberação. Por deliberação, considera-se como a prática inclusiva e respeitosa de interação argumentativa no processo de tomada de decisões coletivas, almejando um consenso, que seria orientado por uma razão imparcial ligada ao bem comum. O processo de deliberação anseia uma prática política, que obviamente apresentará um ônus ao se tomar determinada decisão. Assim, não se concebe isso como um "café filosófico", em que a despretensão em se firmar e delimitar um posicionamento estão presentes.

Propõe-se que os participantes devem estar abertos a serem convencidos. Almeja-se um processo de persuasão e não uma mera coleta de decisões individuais entre seus integrantes. Dentre deste modelo ideal, não há coerção, mas uma espécie de ética do consenso, uma vez que o posicionamento de cada ministro apresenta o mesmo valor, buscando-se a obtenção do melhor argumento existente.

A partir da promessa epistêmica ${ }^{102}$, o processo deliberativo gera melhores decisões em comparação com as que não prestigiam o debate. Nesse contexto, melhores decisões seriam aquelas mais bem informadas, as que estimulam criatividade $\mathrm{e}$ as que diluem tanto os acordos quanto os desacordos argumentativos que são levados ao processo legislativo.

Por outro lado, a promessa educativa ${ }^{103}$, estrutura o desenvolvimento de habilidades instrumentais em si, e por consequência, os deliberadores passam a

\footnotetext{
${ }^{101}$ Defende-se que a deliberação deve ocorrer nos casos que se localizam em uma zona cinzenta de indefinição jurídica por parte do Tribunal, isto é, casos que apresentam decisões incoerentes ao se comparar casos parecidos.

${ }^{102}$ Os partidários do processo de deliberação visualizam quatro tipos de promessa que essa postura pode levar: a) epistêmica; b) comunitária; c) psicológica; d) educativa. Ver: MENDES, Conrado Hübner Mendes. Constitutional Courts and Deliberative Democracy. Oxford Constitutional Theory. Oxford University Press, 2013.

${ }^{103} \mathrm{Idem}$
} 
entender melhor o assunto que está em pauta de discussão.

Com relação ao processo deliberatório, Mendes $^{104}$ identifica fenômenos relativamente diferentes que podem ser interconectados e ocorrem em três momentos ${ }^{105}$ : a) pré-decisório: é a fase da contestação pública em que a Corte é provocada e começa a realizar um debate inicial que, no mínimo, ocorrerá entre as partes do processo; b) engajamento colegiados: neste estágio entrarão em cena os decisores ${ }^{106}$; c) pós-decisório: a Corte vivencia o ideal deliberativo devendo, assim, produzir uma decisão escrita. É nesse estágio que se encontra o ponto nevrálgico de nossa discussão, conforme bem descreve Mendes:

O estágio redacional (terceiro momento) deve, portanto, tentar converter a interação colegiada numa decisão supra individual, produzir um tipo especial de despersonificação que somente um processo deliberativo é capaz de fazer. Uma corte deliberativa, nessa fase, precisa balancear a necessidade de construir uma identidade institucional com o dever de respeitar o lugar de opiniões dissidentes. Ela atribui peso especial à autoria institucional, mas não se furta, a depender da circunstância, de exibir eventual desacordo interno. Uma corte deliberativa não exibe publicamente um tipo qualquer de desacordo, mas somente aqueles que resistiram à interação colegiada. As divisões, quando persistem, são sérias e respeitáveis, não frívolas e caprichosas ${ }^{107}$.

Quanto à decisão deliberativa visualizam-se duas possibilidades: a primeira seria uma decisão proveniente de uma única voz, enquanto a segunda, extraída de múltiplas vozes. Com relação à última, podem-se extrair as seguintes decisões: ${ }^{108}{ }^{109}$ a) seriatim não deliberativa: consiste em uma espécie de "colcha de retalhos", em que há decisões essencialmente individuais que não se comunicariam entre si; b) per curiam não deliberativa- decisão unitária, que não atende o estilo deliberatório; c) seriatim deliberativa: os julgamentos são tomados em série, no entanto há diálogo entre os ministros e d) per curiam deliberativa:

\footnotetext{
${ }^{104}$ MENDES, Conrado Hübner. O projeto de uma corte deliberativa, in Jurisdição Constitucional no Brasil. São Paulo: Malheiros, 2012

${ }^{105}$ Mendes ressalta que uma corte deliberativa do tipo ideal persegue a tarefa correspondente a cada uma das três fases. Idem, p. 59.

${ }^{106} \mathrm{O}$ primeiro momento pode coexistir com o segundo ao mesmo tempo.

${ }^{107}$ MENDES, Conrado Hübner. Op. cit., p. 65.

${ }^{108}$ Ididem, p. 66.

${ }^{109}$ A grande maioria das cortes constitucionais reais oscila entre decisões per curiam puras e decisões intermediárias que mesclam opiniões da corte com votos concorrente e dissidentes. Mendes salienta que raras são as cortes que optam por uma seriatim pura, tal como o Supremo Tribunal Federal. Ididem, p. 67.
} 
aqui um ministro ou juiz não será o responsável pela decisão, havendo os votos dos ministros que são a favor e os que são contra a decisão. Tanto a seriatim deliberativa quanto a percuriam deliberativa apresentam "opiniões individuais que são costuradas de maneira mais explícita, argumentos mútuos são enfrentados, objeções são respondidas e posições são assumidas" $" 110$.

A existência de súmulas (incluem-se as vinculantes), informativos, enunciados, orientações jurisprudenciais "não formam um corpo de argumentos organizados, mas um conjunto de diretivas com a forma de sim/não. Por essa razão, a ideia de precedente é inadequada, ao menos neste momento histórico" no Brasil. ${ }^{111}$ Entende-se que o uso dos precedentes esta ligado à tradição do direito anglo-saxônico, ao passo que nossa tradição romano-germânica constrói um aparato de julgamento bem diferente da common law. Tal fato pode fazer com que se construa a tese de que não há precedentes no direito brasileiro.

Discorda-se da afirmação de que no Brasil não há precedentes, pois, em certa medida, há o uso de casos anteriores que possuem um "núcleo essencial"112 que auxiliam no julgamento de casos parecidos. ${ }^{113}$ Não se defende o uso de precedentes como de uso vinculativo (obrigatório) como algumas teorias defendem, mas se entende que os autoprecedentes são obrigatórios.

No caso de um órgão colegiado, o que importa é que os ministros mantenham a postura anterior, delineando-se, assim, o posicionamento desse órgão em casos futuros. Desse modo, discorda-se de Rodriguez, pois se entende que há precedentes no Brasil e esses devem ser respeitados por juízes e colegiados que já enfrentaram a mesma questão em outra ocasião.

Marinoni qualifica os precedentes do STF como precedentes com eficácia vinculante de decisão proferida: a) em controle difuso, b) controle concentrado como precedente constitucional, c) em repercussão geral no recurso

\footnotetext{
110 Ididem, p. 67.

${ }^{111}$ RODRIGUEZ, José Rodrigo. Op. cit., p. 15.

${ }^{112}$ DIDIER Jr., Fredie; BRAGA, Paula Sarno; OLIVEIRA, Rafael. Op. cit., p. 427.

113 A título de exemplo, ver voto do Ministro Gilmar Mendes nas decisões "D" e "G" (HC n 109.870/RS e $\mathrm{HC} \mathrm{n}^{\circ} 108.872 / \mathrm{RS}$ ) que se valeu de casos parecidos anteriores, no caso das decisões "A" e "F" na fundamentação de seu voto.
} 
extraordinário, d) a partir de súmula e e) a partir de súmula vinculante ${ }^{114}$. No caso, haveria eficácia vinculante, uma vez que os demais órgãos do poder judiciário estariam obrigados a segui-10 ${ }^{115}$.

A afirmação de Conrado Mendes de que é complicado dizer que no Brasil há uma jurisprudência constitucional ${ }^{116}$, pois esta seria a soma de um conjunto de decisões em que não há comunicabilidade entre as mesmas ${ }^{117}$, pode ser inadequada.

A análise dos informativos selecionados permitiu identificar que em alguns casos há jurisprudência ${ }^{118}$. Verificou-se que há decisões harmônicas que guardam, entre si, uma identidade no resultado dos julgamentos. Atenta-se que há fatores que obstam a construção de uma linha de raciocínio mais claro. Por exemplo, a redação das ementas pode gerar a falsa impressão de que há decisões incoerentes em casos parecidos ${ }^{119}$.

\footnotetext{
${ }^{114}$ MARINONI, Luiz Guilherme. Op. cit., p. 458-493.

${ }^{115}$ A pesquisa não se alinha ao entendimento de que os demais juízes de outras instâncias e tribunais estariam coagidos, em certa medida, a seguir as decisões do STF.

${ }^{116}$ Mendes fala de "jurisprudência constitucional" em um sentido genuíno, isto é, por genuíno o mesmo "não estaria se referindo a uma prática de obediência cega e incondicional a precedentes, mas a um esforço de costurar o passado, presente e futuro, de escrever um 'romance em cadeia'". MENDES, Conrado Hübner. Direitos fundamentais, separação de poderes e deliberação. Tese de Doutorado. Universidade de São Paulo. Faculdade de Filosofia, Letras, e Ciências Humanas, p. 254.

${ }^{117}$ Idem, p. 254.

${ }^{118}$ Como será observado, a pesquisa identificou que há jurisprudência sobre o tema selecionado na Primeira Turma do STF, enquanto na Segunda Turma não há.

${ }^{119}$ Esse fator será analisado na presente pesquisa. Ver itens 4.1. e 4.3. .
} 


\section{3}

\section{Relatório das decisões}

Em um universo de nove decisões proferidas pela Segunda Turma do STF em sede de habeas corpus, que versam sobre a aplicação ou não do princípio da insignificância a pacientes reincidentes, percebe-se uma incoerência na postura de alguns ministros. A análise será dividida em dois blocos: o primeiro tratará das decisões sobre furto simples consumado, enquanto o segundo abordará julgados de furto simples tentado.

O relatório é separado em cinco categorias: a) composição da bancada, b) qualificação do caso, c) exposição das decisões, d) estrutura do inteiro teor e e) quadro resumo dos votos. Com relação à estrutura do inteiro teor, examinaram-se os seguintes aspectos: a) quantidade de páginas que compõe o inteiro teor; b) quais ministros proferiram votos com alguma fundamentação, sem que tenham, simplesmente, acompanhado o relator ou outro ministro; c) quais ministros fizeram alguma referência à doutrina; d) se no voto há a mera citação ${ }^{120}$ de algum julgamento anterior do Supremo Tribunal federal; e) quais ministros fizeram a transcrição de ementa ou parte de inteiro teor e quais foram esses julgados; f) se houve debate $\left.{ }^{121} ; \mathrm{g}\right)$ considerações sobre a ementa e h) se houve pedido de votovista.

Antes de iniciar o relatório das decisões, de forma a auxiliar o estudo nos casos selecionados na presente pesquisa, é interessante pontuar breves conceitos

\footnotetext{
${ }^{120}$ Aferiu-se se houve a menção a algum julgamento e a mera referência ao número do julgado, sem que tenha sido transcrita sua ementa ou parte do seu inteiro teor.

${ }^{121}$ Por "debate", considera-se como sendo qualquer diálogo entre os ministros. Nessa análise não será aferido se houve uma deliberação em seu caráter genuíno.
} 
de Direito Penal. A abordagem será em torno dos conceitos de: a) crime consumado, b) tentativa, c) crime simples, d) furto simples, e) reincidência e maus antecedentes e f) princípio da insignificância.

\section{A. Crime consumado}

Com base no art. 14, inc I do CP sabe-se que ocorre a consumação de um crime quando nele se reúnem todos os elementos de sua definição legal. Em outras palavras, quando um agente pratica uma conduta típica e nela se realiza todos os elementos que constituem o tipo penal, haverá a consumação de um crime.

É interessante ressaltar a diferença existente entre consumação de um crime e exaurimento de uma conduta. Salim e Azevedo destacam que no caso, "o crime pode estar consumado sem que tenha produzido o resultado desejado pelo agente. O conceito de crime consumado (art. 14, I) deve ser entendido como consumação em um sentido técnico, pois alguns crimes podem se consumar mesmo que não ocorra o resultado perseguido pelo agente" ${ }^{\text {"122 }}$.

\section{B.Tentativa}

A tentativa ${ }^{123}$ está disciplinada no art. 14 , inc II do CP determinando que uma vez iniciada a execução, esta não se consumará por circunstâncias alheias à vontade do agente. Destaca-se que com relação à tentativa "o fato praticado não corresponde à totalidade dos elementos objetivos de um tipo penal (...) os elementos objetivos (tipo objetivo) se realizam parcialmente, embora se realizem

\footnotetext{
${ }^{122}$ SALIM, Alexandre; AZEVEDO, Marcelo André de. Direito Penal- Parte Geral. $3^{\text {a }}$ edição. Salvador: Juspodivm, 2013, p. 228.

${ }^{123}$ Há quem se refira à tentativa como conatus, crime imperfeito ou crime incompleto.
} 
completamente os elementos subjetivos (tipo subjetivo)" ${ }^{\text {"124 }}$.

A tentativa se enquadra como uma norma de extensão temporal ou de ampliação da conduta, isto porque a tentativa não é um tipo penal, mas sim uma norma que, a depender do caso concreto, poderá servir como uma norma de extensão daquela conduta. Zaffaroni e Pierangeli elucidam que não existe um delito denominado tentativa, mas há tentativas de delitos ${ }^{125}$.

A pena da tentativa não é a mesma do crime consumado. Conforme disciplina o art. 14 do CP sabemos que: "salvo disposição em contrário, pune-se a tentativa com a pena correspondente ao crime consumado, diminuída de um a dois terços". Essa diminuição de pena enquadra-se como uma causa de diminuição de pena. A exceção que existe na legislação ocorre quando no tipo penal há também referência à forma tentada ${ }^{126}$.

Há alguns crimes que não admitem tentativa: a) culposo $^{127}$, b) preterdoloso $^{128}$, c) omissivo impróprio ${ }^{129}$, d) unissubsistente ${ }^{130}$, e) habitual ${ }^{131}$, f) de atentado $^{132}$ e g) condicionado ${ }^{133}$. Por fim, recorda-se que as contravenções penais não admitem a tentativa, conforme art. $4^{\circ}$ do decreto-lei 3.688/41.

\section{Crime simples}

Crime simples é aquele representado pelo tipo penal básico ou

\footnotetext{
${ }^{124}$ SALIM, Alexandre; AZEVEDO, Marcelo André de. Op. cit., p. 228.

125 ZAFFARONI, Eugênio Raul; PIERANGELI, José Henrique Da Tentativa: Doutrina e Jurisprudência, $6^{\circ}$ edição, RT, 2000.

${ }^{126}$ Um bom exemplo é o art. 352 do CP: Evadir-se ou tentar evadir-se o preso ou o indivíduo submetido a medida de segurança detentiva, usando de violência contra a pessoa: Pena - detenção, de três meses a um ano, além da pena correspondente à violência.

${ }^{127}$ No crime culposo o resultado será produzido por negligência, imprudência ou imperícia. Frisase que a tentativa necessita de dolo, assim não há como se tentar um crime culposo.

${ }^{128}$ Crime preterdoloso consiste em um crime que é culposo e doloso ao mesmo tempo. Tem-se que o agente age com dolo no resultado antecedente e culpa no consequente, visto que ele atinge o resultado, porém de um modo pior que desejava.

${ }^{129}$ A norma incriminadora descreve aquilo que o agente não faz.

${ }^{130}$ Crime que possui apenas uma única conduta.

${ }^{131}$ Crime que o indivíduo só pratica quando o mesmo faz algo de forma habitual, reiterada. Frisase que a corrente majoritária entende que o crime habitual não admite a tentativa.

${ }_{132}$ Crime em que o ato de simplesmente tentar a conduta, faz com que se consume o crime.

${ }^{133}$ A consumação do crime condiciona-se a um evento posterior à consumação.
} 
fundamental, sem que haja a incidência de qualquer circunstância que possa aumentar ou diminuir a pena apresentada no caput do artigo. Como exemplo de crimes simples temos o furto simples (art. 155, caput, CP), homicídio simples (art. 121, caput, CP), receptação simples (art. 180, caput, CP), dentre outros.

\section{Furto simples}

O furto simples ocorre quando há subtração, para si ou para outrem, de coisa alheia móvel (art. 155, caput, CP). Trata-se de um crime contra o patrimônio no qual se subtraem bens alheios. Por coisa alheia, entende-se aquela que possui algum dono ${ }^{134}$. Já coisa móvel compreende o conjunto de objetos que não são imóveis. Para que um objeto seja móvel é necessário que ele possa ser transportado $^{135}$. Segundo Eduardo e Gonçalves a subtração ocorre em duas circunstâncias:

A primeira delas, mais óbvia, dá-se quando o agente, sem qualquer autorização, apodera-se da coisa alheia e a leva embora, causando, assim, prejuízo econômico à vítima que fica despojada do bem que lhe pertence.(...) Já a segunda forma de subtração necessita de maior atenção para que não seja confundida com o crime de apropriação indébita. É que doutrinadores e julgadores, levando em conta a característica do furto, no sentido de que o bem deve ser tirado da esfera de vigilância do dono, concluíram que, se a própria vítima o entrega ao agente, mas não autoriza que ele deixe o local em sua posse, porém ele, sorrateiramente ou mediante fuga, tira o bem dali, o crime é de furto. Em tal caso diz-se que a posse ou detenção eram vigiadas, e que o agente, ao levar o bem, tirou-o da esfera de vigilância do dono, cometendo, portanto, furto ${ }^{136}$.

\section{E. Reincidência e maus antecedentes}

A reincidência (art. 61, inc I, CP) é uma circunstância agravante

\footnotetext{
${ }^{134}$ Não há furto de um objeto que não possua dono, pois para haver furto, necessita-se que a coisa tenha um proprietário.

${ }^{135} \mathrm{O}$ Código Penal no art. $155, \S 3^{\circ}$ considera coisa móvel a energia elétrica e outras formas equiparadas, que de algum modo, possuam expressão econômica.

${ }^{136}$ EDUARDO, Victor; GONÇALVES, Rios. Direito Penal Esquematizado- Parte Especial. São Paulo: Saraiva, 2011, p. 309-310.
} 
empregada na segunda fase de aplicação da pena. Seu cômputo leva em consideração o art. 64, inc I, $\mathrm{CP}^{137}$.

Ressalta-se que o instituto da reincidência deve considerar dois aspectos: a) um sujeito é reincidente apenas quando houver sentença penal com trânsito em julgado; b) não se levam em conta para efeito da reincidência, ações penais em curso sem sentença definitiva de mérito e inquéritos policiais. De forma didática, com base no art. $63, \mathrm{CP}^{138}$ e art. $7^{\circ}$ da Lei das Contravenções Penais ${ }^{139}$, tem-se que:

\begin{tabular}{|c|c|} 
Crime + crime & Há reincidência \\
Crime + contravenção & Há reincidência \\
Contravenção + crime & Não há reincidência \\
\hline Contravenção + contravenção & $\begin{array}{c}\text { Há reincidência, desde que a primeira } \\
\text { contravenção tenha sido cometida no } \\
\text { Brasil e possua trânsito em julgado }\end{array}$ \\
\hline
\end{tabular}

Tabela 01- Quadro esquemático reincidência

Por outro lado, os maus antecedentes estão elencados pelo legislador no art. 59, caput do $\mathrm{CP}^{140}$. Eles representam circunstâncias judiciais que poderão ser utilizadas pelo juiz na primeira fase de aplicação da pena. Os maus antecedentes não possuem um conceito próprio, sendo que a doutrina entende que seria tudo aquilo que remanesce a reincidência.

137 Art. 64, CP - Para efeito de reincidência: I - não prevalece a condenação anterior, se entre a data do cumprimento ou extinção da pena e a infração posterior tiver decorrido período de tempo superior a 5 (cinco) anos, computado o período de prova da suspensão ou do livramento condicional, se não ocorrer revogação;

138 Art. 63, CP - Verifica-se a reincidência quando o agente comete novo crime, depois de transitar em julgado a sentença que, no País ou no estrangeiro, o tenha condenado por crime anterior.

${ }^{139}$ Art. $7^{\circ}$, LCP: Verifica-se a reincidência quando o agente pratica uma contravenção depois de passar em julgado a sentença que o tenha condenado, no Brasil ou no estrangeiro, por qualquer crime, ou, no Brasil, por motivo de contravenção.

140 Art. 59, CP: O juiz, atendendo à culpabilidade, aos antecedentes, à conduta social, à personalidade do agente, aos motivos, às circunstâncias e consequências do crime, bem como ao comportamento da vítima, estabelecerá, conforme seja necessário e suficiente para reprovação e prevenção do crime: (...). 


\section{F. Princípio da insignificância ou da bagatela}

O princípio da insignificância considera que quando uma conduta produz algum dano ou perigo de âmbito insignificante na seara penal, não deverá essa servir como motivo para a movimentação da máquina da justiça estatal. Condutas de bagatela ou insignificantes seriam consideradas como sendo materialmente atípicas. Bitencourt complementa que:

A tipicidade penal exige uma ofensa de alguma gravidade aos bens jurídicos protegidos, pois nem sempre qualquer ofensa a esses bens ou interesses é suficiente para configurar o injusto típico. Segundo esse princípio, que Klaus Tiedemann chamou de princípio da bagatela, é imperativa uma efetiva proporcionalidade entre a gravidade da conduta que se pretende punir e a drasticidade da intervenção estatal. Amiúde, condutas que se amoldam a determinado tipo penal, sob o ponto de vista formal, não apresentam nenhuma relevância material. Nessas circunstâncias, pode-se afastar liminarmente a tipicidade penal porque em verdade o bem jurídico não chegou a ser lesado ${ }^{141}$.

Apesar de alguns pontos serem controversos perante o Supremo Tribunal Federal, pode-se afirmar que o princípio da insignificância "deve ser analisado em conexão com os postulados da fragmentariedade e da intervenção mínima do Estado em matéria penal, que tem o sentido de excluir ou de afastar a própria tipicidade penal, examinada na perspectiva de seu caráter material"142.

Além disso, consolidou-se o entendimento que na aplicação do princípio da insignificância, deve-se considerar durante a avaliação material da tipicidade penal, alguns vetores, tais como: a) mínima ofensividade da conduta do agente; b) nenhuma periculosidade social da ação; c) reduzidíssimo grau de reprovabilidade do comportamento e d) inexpressividade da lesão jurídica provocada, conforme o $\mathrm{HC} \mathrm{n}^{\mathrm{o}} 118.738 / \mathrm{MG}^{143}$. Frisa-se que esses critérios apresentam correlação com os aspectos objetivos do fato.

Uma grande divergência presente entre as turmas do Supremo Tribunal Federal está na possibilidade de se considerar a reincidência na análise dos critérios objetivos. A Primeira Turma do STF entende que se deve fazer uma

\footnotetext{
${ }^{141}$ BITENCOURT, Cezar Roberto. Tratado de Direito Penal. $15^{\text {a }}$ edição. São Paulo: Ed. Saraiva, 2010, p. 51.

${ }^{142}$ BRASIL, STF, HC nº 106.510/MG, Rel. Min. Joaquim Barbosa, Dje: 22.03.2011.

${ }^{143}$ BRASIL, STF, HC n ${ }^{\circ}$ 118.738/MG, Rel. Min. Gilmar Mendes, Dje: 21.11.2013.
} 
ressalva, admitindo que "apesar de ser critério subjetivo, a reincidência remete a critério objetivo e deve ser excepcionada da regra para análise do princípio da insignificância"144. Em uma rápida pesquisa feita no site do Supremo, observamse mais 4 (quatro) acórdãos, todos da Primeira Turma que possuem essa ressalva em sua própria ementa.

Por outro lado, até o presente momento, a Segunda Turma entende de modo contrário, conforme se observa na "Decisão F" $\left(\mathrm{HC} \mathrm{n}^{\mathrm{o}} 106.510 / \mathrm{MG}\right)^{145}$ dispondo a existência de condições pessoais, leia-se reincidência, não tem o condão de impedir a aplicação do princípio da insignificância.

\section{1 Habeas corpus em casos de furto simples consumado}

A análise selecionou 5 (cinco) habeas corpus proferidos pela Segunda Turma do Supremo: HC no 93.393/RS, HC no 97.007/SP, HC no 107.184/RS, HC $\mathrm{n}^{\mathrm{o}}$ 109.870/RS e HC n ${ }^{\mathrm{o}}$ 118.089/MG, apelidados, respectivamente, de decisão "A", "B", "C", "D” e "E" para facilitar a análise. A partir dessas decisões, observa-se que sobre o tema aplicação ou não do princípio da insignificância a pacientes reincidentes que praticaram furto simples consumado ${ }^{146}$, a Segunda Turma do STF não possui uma posição definida em casos parecidos, ou seja, não há um respeito aos autoprecedentes. Isso é comprovado com base nas decisões

\footnotetext{
${ }^{144}$ BRASIL, STF, HC no 111.394/MG, Rel. Min. Cármen Lúcia, Dje: 16.10.2013.

${ }^{145}$ Decisão veiculada no informativo $\mathrm{n}^{\circ}$ 620. O informativo veiculou a seguinte notícia: "Reincidência e princípio da insignificância: Ante o empate na votação, a $2^{\mathrm{a}}$ Turma deferiu habeas corpus impetrado em favor de condenado à pena de 10 meses de reclusão, em regime semiaberto, pela prática do crime de furto tentado de bem avaliado em $\mathrm{R} \$ 70,00$. Reputou-se, ante a ausência de tipicidade material, que a conduta realizada pelo paciente não configuraria crime. Aduziu-se que, muito embora ele já tivesse sido condenado pela prática de delitos congêneres, tal fato não poderia afastar a aplicabilidade do referido postulado, inclusive porque estaria pendente de análise, pelo Plenário, a própria constitucionalidade do princípio da reincidência, tendo em vista a possibilidade de configurar dupla punição ao agente. Vencidos os Ministros Joaquim Barbosa, relator, e Ayres Britto, que indeferiam o writ, mas concediam a ordem, de ofício, a fim de alterar, para o aberto, o regime de cumprimento de pena" (STF: $\mathrm{HC} \mathrm{n}^{\circ}$ 106.510/MG, Segunda Turma, Rel. Min. Joaquim Barbosa, Dje: 13.06.2011).

${ }^{146}$ Desconsidera-se a incidência de qualquer atenuante, agravante (excetua-se a reincidência), qualificadora, concurso de crimes ou concurso de pessoas.
} 
dos Ministros Ayres Britto, Ricardo Lewandowski, Gilmar Mendes, Joaquim Barbosa e Celso de Mello.

Nos 5 (cinco) habeas corpus há decisões unânimes que concedem a ordem $^{147}$ e decisões unânimes que denegam a ordem ${ }^{148}$, conforme "Quadro 03". Isso ocorreu em virtude da inconsistência manifestada pelos Ministros supracitados da Segunda Turma que ora aplicam o princípio da insignificância, ora não o aplicam.

Em momento algum os ministros em referência fizeram uma ressalva em seu voto ou argumentaram de modo que se pudesse verificar em seu parecer a existência de um overruling, overriding, distinguishing ou transformation. Assim, não foi encontrada uma linha de raciocínio que justifique um tratamento diferenciado em casos parecidos, quanto à aplicação do princípio da insignificância.

\subsection{1}

\section{"Decisão A"- HC n 93.393/RS ${ }^{149}$}

\section{A. Composição da bancada}

Presentes à sessão os Ministros Celso de Mello, Cezar Peluso (Relator), Eros Grau, Joaquim Barbosa. Ausente, justificadamente, a Ministra Ellen Gracie.

\footnotetext{
${ }^{147} \mathrm{HC} \mathrm{n}^{\circ} 93.393 / \mathrm{RS}$ e $\mathrm{HC} \mathrm{n}^{\circ} 107.184 / \mathrm{RS}$.

${ }^{148} \mathrm{HC} \mathrm{n}^{\circ} 97.007 / \mathrm{SP}$ e HC no $118.089 / \mathrm{MG}$

149 BRASIL. Supremo Tribunal Federal. Habeas Corpus no 93.393/RS. Segunda Turma. Ação Penal. Justa causa. Inexistência. Delito de furto. Subtração de roda sobressalente com pneu de automóvel estimados em R\$ 160,00 (cento e sessenta reais). Res Crime de bagatela. Aplicação do princípio da insignificância. Irrelevância de considerações de ordem subjetiva. Atipicidade reconhecida. Absolvição. HC concedido para esse fim. Precedentes. Verificada a objetiva insignificância jurídica do ato tido por delituoso, é de ser afastada a condenação do agente, por atipicidade do comportamento. Relator: Ministro Cezar Peluso. Paciente: Roque César Rodrigues. Coator: Superior Tribunal de Justiça. Brasília, DF, Dje: 15 de maio de 2009. Disponível $\mathrm{em}:<\mathrm{http}: / /$ redir.stf.jus.br/paginadorpub/paginador.jsp?docTP=AC\&docID $=592530>$. Acesso em: 04 de novembro de 2013.
} 


\section{B. Qualificação do caso}

O caso trata da possibilidade da aplicação ou não do princípio da insignificância a um paciente que cometeu furto consumado de uma roda sobressalente com pneu de automóvel avaliados em torno de $\mathrm{R} \$ 160,00$ (cento e sessenta reais).

\section{Exposição das decisões}

O paciente foi condenado em primeira instância. A defesa recorreu e o Tribunal de Justiça do Rio Grande do Sul concedeu a ordem, absolvendo o paciente com base no princípio da insignificância. O Ministério Público ingressou com Recurso Especial no Superior Tribunal de Justiça, argumentando que não seria um caso passível de aplicação do referido princípio. Houve provimento do Recurso Especial, e alegou-se que "a reincidência específica do agente é causa suficiente a ensejar a maior rigidez na penalização da conduta (...) incluída no rol de causas agravantes da pena, denotando a preocupação do legislador em despender tratamento mais rigoroso" ${ }^{" 150}$. Contra essa decisão que restabeleceu a condenação do paciente nas penas do art. 155 c/c arts14, II e 61 , I do $\mathrm{CP}^{151}$, foi impetrado habeas corpus perante o Supremo Tribunal Federal, com pedido de liminar que foi deferida, justamente por ter sido verificado fumus boni iuris no caso.

\footnotetext{
150 BRASIL. Superior Tribunal de Justiça. Recurso Especial no ${ }^{\circ}$ 961.844. Quinta turma. Penal. Recurso especial. Furto. Bem de pequeno valor (R\$ 160,00). Princípio da insignificância. Reincidência. Periculosidade do agente. Inaplicabilidade. Provimento. Recorrente: Ministério Público do Estado do Rio Grande do Sul. Recorrido: Roque César Rodrigues (preso). Relator: Ministro Napoleão Nunes Maia Filho. Brasília, DF, 19 de novembro de 2007. Disponível em: $<\mathrm{http} / / /$ www.stj.jus.br/websti/processo/Justica/detalhe.asp?numreg=200701410144\&pv=01000000 0000\&tp $=51>$. Acesso em: 05 de nov. 2013.

${ }^{151}$ Art. 14, CP - Diz-se o crime: II - tentado, quando, iniciada a execução, não se consuma por circunstâncias alheias à vontade do agente. Art. $61, \mathrm{CP}$ - São circunstâncias que sempre agravam a pena, quando não constituem ou qualificam o crime: I - a reincidência;
} 
O julgamento do HC 93393/RS ocorreu em 14.04.2009 tendo como Relator o Ministro Cezar Peluso. Seu inteiro teor é composto tão somente do relatório e da transcrição do voto integral do relator. A decisão foi unânime no sentido da concessão da ordem de habeas corpus, absolvendo, assim, o paciente.

Peluso confirma a liminar sustentando que:

a) na avaliação da possibilidade de aplicação do princípio da insignificância, devem-se considerar as circunstâncias objetivas e desconsiderar as circunstâncias subjetivas em sua análise; b) a decisão do Recurso Especial foi baseada, principalmente, na reincidência específica do réu, fato este que afastou o mencionado princípio;

c) na aplicação do princípio da bagatela não se pode considerar as características subjetivas do agente;

d) no presente caso, concede-se a ordem, absolvendo-se o paciente.

\section{Estrutura do inteiro teor}

\begin{tabular}{|c|c|}
\hline Páginas do inteiro teor & 9 páginas \\
\hline Transcrição integral do voto & Ministro Cezar Peluso (Relator) \\
\hline Citação de doutrina & Não \\
\hline Citação de julgamento anterior & Não \\
\hline $\begin{array}{l}\text { Transcrição de ementa ou parte de } \\
\text { inteiro teor }\end{array}$ & $\begin{array}{l}\text { - HC n 84.424/SP, Primeira Turma, } \\
\text { Rel. Min. Carlos Britto, DJ: } \\
\text { 07.10.2005; } \\
\text { - HC n 84.412/SP, Segunda Turma, } \\
\text { Rel. Min. Celso de Mello, DJ: } \\
\text { 19.11.2004; } \\
\text { - HC n 77.003/PE, Segunda Turma, } \\
\text { Rel. Min. Marco Aurélio, DJ: } \\
\text { 11.09.1998; } \\
\text { - HC n 88.393/RJ, Segunda Turma, } \\
\text { Rel. Min. Cezar Peluso, DJ: } \\
\text { 08.06.2007. }\end{array}$ \\
\hline $\begin{array}{l}\text { Transcrição de algum parecer ou } \\
\text { manifestação? }\end{array}$ & Não \\
\hline
\end{tabular}




\begin{tabular}{|l|l|} 
Houve debate? & Não \\
Considerações sobre a ementa & - Não fala que o paciente é reincidente; \\
Houve pedido de vista? & Não
\end{tabular}

Tabela 02- Estrutura do inteiro teor da "Decisão A"

\section{E. Quadro resumo dos votos}

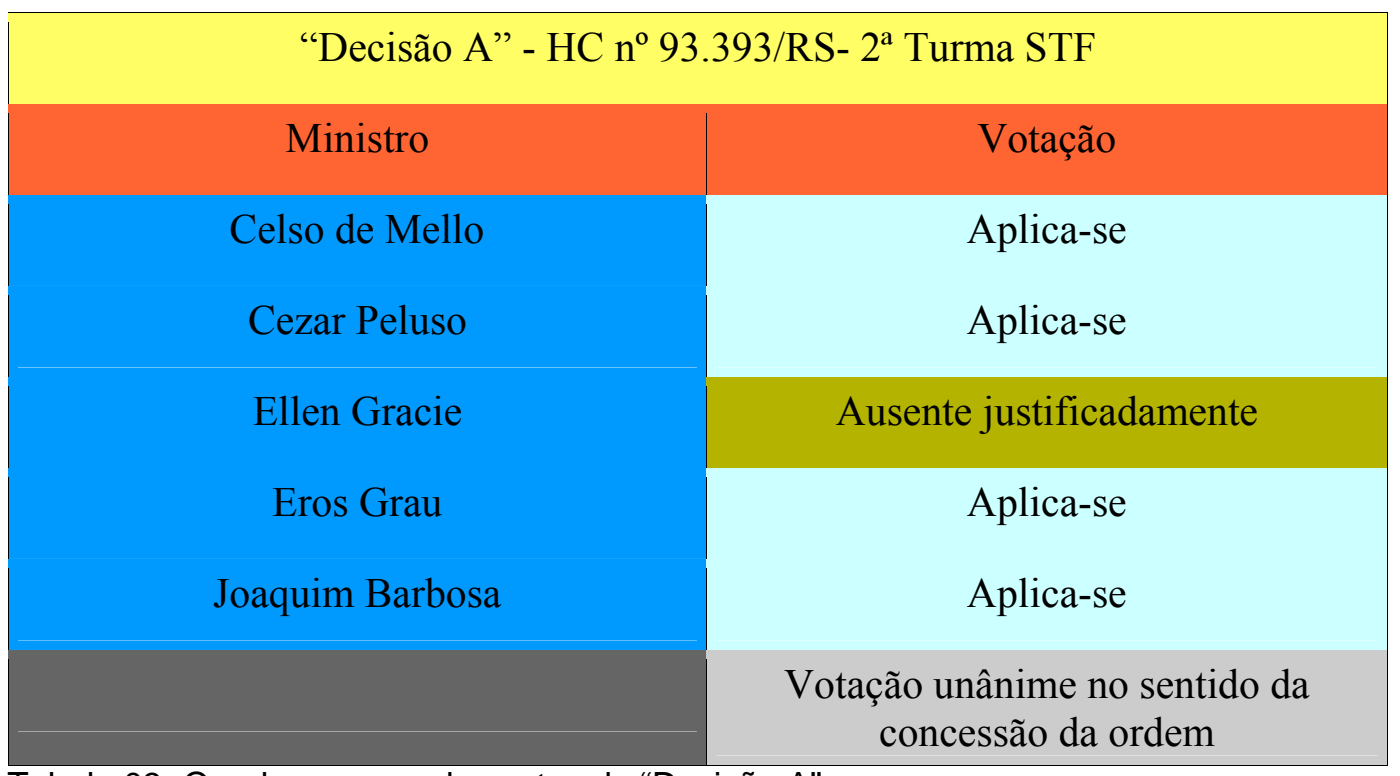

Tabela 03- Quadro resumo dos votos da "Decisão A"

\section{1 .2}

\section{"Decisão B"- HC n 97.007/SP"152}

\footnotetext{
${ }^{152}$ BRASIL. Supremo Tribunal Federal. HC n ${ }^{\circ}$ 97.007/SP. Segunda Turma. Habeas Corpus. Penal e Processual Penal. Furto. Incidência do princípio da insignificância. Inviabilidade. Reincidência e habitualidade delitiva comprovadas. Ordem denegada. Reconhecidas a reincidência e a habitualidade da prática delituosa, a reprovabilidade do comportamento do agente é significativamente agravada, sendo suficiente para inviabilizar a incidência do princípio da insignificância. Precedentes. Ordem denegada. Paciente: Eduardo Machado Bailon. Coator: Superior Tribunal de Justiça. Brasília, DF, Dje 31 de março de 2011. Disponível em: $<$ http://redir.stf.jus.br/paginadorpub/paginador.jsp?docTP $=\mathrm{AC} \&$ docID=621258>. Acesso em: 13 de novembro de 2013.
} 


\section{A. Composição da bancada}

Presentes à sessão os Ministros Ayres Britto, Celso de Mello, Ellen Gracie, Gilmar Mendes e Joaquim Barbosa (Relator).

\section{B. Qualificação do caso}

O caso examina a incidência ou não do princípio da insignificância a um paciente que subtraiu $\mathrm{R} \$ 5,00$ (cinco reais) da vítima e seus documentos pessoais.

\section{Exposição das decisões}

O paciente foi denunciado pela prática de furto (art. 155, CP) de R $\$ 5,00$ (cinco reais), além de ter subtraído documentos pessoais da vítima. A defesa impetrou habeas corpus tanto no Tribunal de Justiça quanto no Superior Tribunal de Justiça objetivando o trancamento da ação penal. Em ambos os tribunais ocorreu a denegação da ordem. A defesa impetrou habeas corpus, com pedido de liminar perante o Supremo Tribunal Federal, requerendo o reconhecimento da aplicação do princípio da bagatela. O Ministro Joaquim Barbosa indeferiu a liminar.

O julgamento ocorreu no dia 01.02.2011 tendo como Relator o Ministro Joaquim Barbosa. O inteiro teor do acórdão é composto apenas da transcrição do voto do Relator. A decisão foi unânime no sentido da denegação da ordem de habeas corpus.

Barbosa destaca que:

a) foram furtados $\mathrm{R} \$ 5,00$ (cinco reais) além dos documentos pessoais da vítima;

b) apesar do baixo valor da quantia subtraída, o agente é reincidente e criminoso habitual, tendo sido condenado por crimes semelhantes. Com base na 
exposição do Ministério Público, o paciente tem 5 (cinco) inquéritos policiais e 6 (seis) ações penais por crime de furto, roubo e porte de arma;

c) o ministro cita o $\mathrm{HC} \mathrm{n}^{\mathrm{o}} 100.240 / \mathrm{RJ}^{153}$, ressaltando que o criminoso habitual não pode ser comparado e ter o mesmo acolhimento jurídico que o criminoso que cometeu um ato único.

d) vota pela denegação da ordem;

\section{Estrutura do inteiro teor}

\begin{tabular}{|c|c|}
\hline Páginas do inteiro teor & 6 páginas \\
\hline Transcrição integral do voto & Ministro Joaquim Barbosa (Relator) \\
\hline Citação de doutrina & Não \\
\hline Citação de julgamento anterior & $\begin{array}{l}\text { - HC n }{ }^{\circ} \text { 100.240/RJ, Segunda Turma, } \\
\text { Rel. Min. Joaquim Barbosa, Dje: } \\
\text { 07.12.2010 }\end{array}$ \\
\hline $\begin{array}{l}\text { Transcrição de ementa ou parte de } \\
\text { inteiro teor }\end{array}$ & $\begin{array}{l}\text { - HC no } 97.772 / R S \text {, Primeira Turma, } \\
\text { Rel. Min. Cármen Lúcia, Dje: } \\
\text { 20.11.2009 }\end{array}$ \\
\hline $\begin{array}{l}\text { Transcrição de algum parecer ou } \\
\text { manifestação? }\end{array}$ & Ministério Público Federal \\
\hline Houve debate? & Não \\
\hline Considerações sobre a ementa & $\begin{array}{l}\text { - Fala que o paciente é reincidente; } \\
\text { - Diz que há precedentes. }\end{array}$ \\
\hline Houve pedido de vista? & Não \\
\hline
\end{tabular}

Tabela 04- Estrutura do inteiro teor da "Decisão B"

\section{E. Quadro resumo dos votos}

“Decisão B”- HC n 9 97.007/SP- 2a Turma STF

\begin{tabular}{l|l} 
Ministro & Votação
\end{tabular}

${ }^{153}$ BRASIL, STF, HC n ${ }^{\circ}$ 100.240/RJ, Min. Rel. Joaquim Barbosa, Dje: 02.03.2011. 


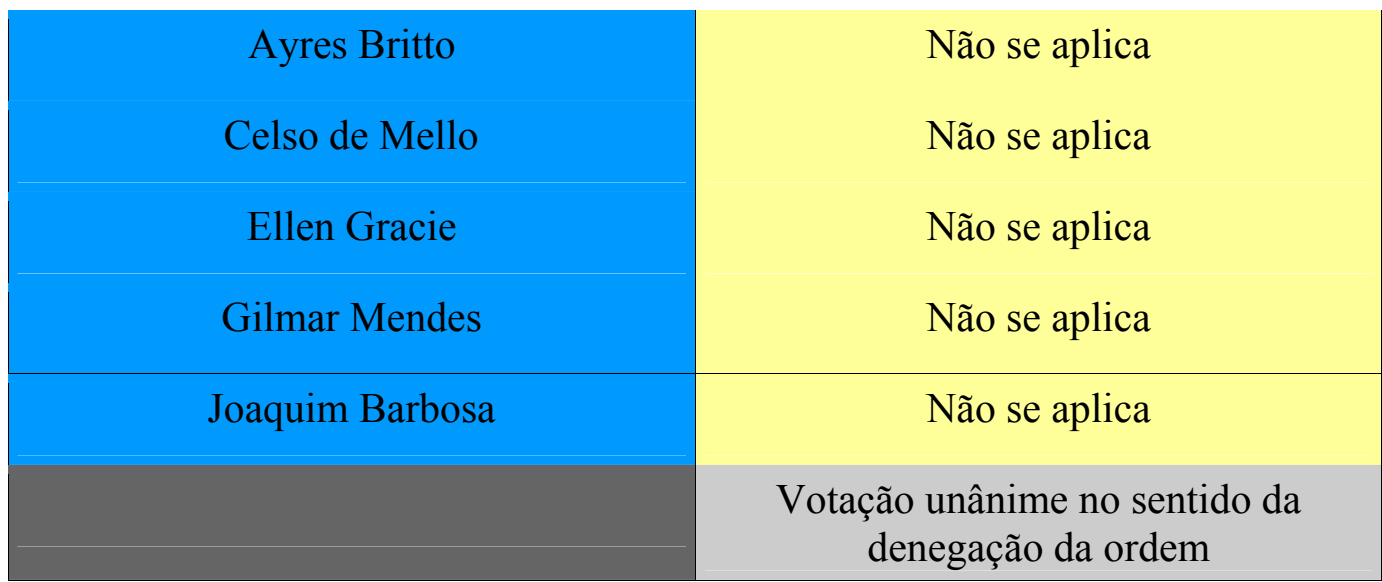

Tabela 05- Quadro resumo dos votos da "Decisão B"

\subsection{3}

\section{"Decisão C"- HC no 107.184/RS ${ }^{154}$}

\section{A. Composição da bancada}

Presentes os Ministros Ayres Britto, Celso de Mello, Gilmar Mendes (Relator), Joaquim Barbosa e Ricardo Lewandowski.

\section{B. Qualificação do caso}

O presente julgado aborda a possibilidade de aplicação do princípio da bagatela a um paciente que furtou 2 (duas) gaiolas e 4 (quatro) pássaros de espécies não protegidas (caturrita e periquito australiano) com o valor aproximado de $\mathrm{R} \$ 29,00$ (vinte nove reais).

\footnotetext{
154 BRASIL. Supremo Tribunal Federal. Habeas corpus $n^{\circ}$. 107.184/RS. Segunda Turma. Habeas corpus. 2. Furto. Bem de pequeno valor ( $\$ 29,00)$. Mínimo grau de lesividade da conduta. 3. Aplicação do princípio da insignificância. Possibilidade. Precedentes. 4. Ordem concedida. Paciente: Vantemar Barbosa. Coator: Relator do habeas corpus $\mathrm{n}^{\circ} 175275$ do Superior Tribunal Federal Relator: Ministro Gilmar Mendes. Brasília, DF. Dje: 21 de novembro de 2011. Disponível em: $<$ http://redir.stf.jus.br/paginadorpub/paginador.jsp?doctp=tp\&docid=1578682 >. Acesso em: 28 de nov. 2013.
} 


\section{Exposição das decisões}

O paciente foi denunciado pela prática de furto (art. 155, CP), sendo absolvido em primeira instância. O Ministério Público recorreu por meio de apelação criminal. O Tribunal de Justiça do Rio Grande do Sul deu provimento ao recurso sustentando que na análise da aplicação do princípio da insignificância, "há que se levar em conta o desvalor da conduta e do resultado, a repercussão do fato na pessoa da vítima e as condições pessoais do acusado, que no caso é reincidente". O Tribunal de Justiça condenou o paciente a 1 (um) ano e 8 (oito) meses de reclusão, em regime semiaberto e ao pagamento de 12 (doze) diasmulta. A defesa impetrou habeas corpus perante o Superior Tribunal de Justiça com pedido de liminar intentando sobrestar o feito. A liminar foi indeferida. Dessa forma, a defesa impetrou o presente habeas corpus objetivando o abrandamento da Súmula 691 do $\mathrm{STF}^{155}{ }^{156}$, para que possa ser aplicado o princípio da insignificância.

O julgamento ocorreu em duas etapas. A primeira delas ocorreu no dia 29.03.2011, tendo sido proferido o voto do Ministro Relator Mendes. Nessa sessão, o Ministro Ayres Britto pediu vista dos autos. A segunda etapa ocorreu no dia 18.10.2011 sendo constituída pelo voto vista de Ayres Britto. O inteiro teor é composto da transcrição integral dos votos dos Ministros Gilmar Mendes e Ayres Britto. Por unanimidade dos votos foi concedida a ordem de habeas corpus.

Gilmar Mendes consignou que:

a) a não aplicação da Súmula 691 do STF, visto que o rigor em sua aplicação tem sido atenuado pelo próprio Supremo Tribunal Federal em situações

\footnotetext{
155 Súmula 691 STF: não compete ao Supremo Tribunal Federal conhecer de habeas corpus impetrado contra decisão do relator que, em "habeas corpus" requerido a tribunal superior, indefere a liminar.

${ }^{156}$ A título de curiosidade: dos 380 (trezentos e oitenta) acórdãos julgados pelo STF em que há a referência a palavra "súmula 691", verificou-se que em 102 (cento e dois) utilizou-se a expressão "superação", em 50 (cinquenta) "óbice" e em 3 (três) "afastamento". Ou seja, em 155 (cento e cinquenta e cinco) julgamentos o STF afastou a súmula 691 do STF. Aponta-se um assunto que poderá ser objeto de futuras pesquisas.
} 
excepcionais que: I) seja urgente a concessão do provimento cautelar para que se possa evitar um flagrante constrangimento ilegal; II) o tribunal superior tido como coator da decisão estaria negando em sede de liminar uma questão que estaria manifestamente contrária à jurisprudência do STF;

b) o presente caso enseja a superação da Súmula $691 \mathrm{STF}$, pois em casos semelhantes, o STF tem reconhecido a aplicação do princípio da insignificância;

c) o Estado não pode se preocupar com condutas irrelevantes para o direito penal;

d) o prejuízo material foi ínfimo, no caso 2 (duas) gaiolas e 4 (quatro) pássaros não protegidos que correspondiam monetariamente a $\mathrm{R} \$ 29,00$ (vinte e nove reais);

e) em que se pese o paciente possuir antecedentes judiciais, tal fato não acarretaria a não aplicação do princípio da insignificância, visto que o STF consolidou o entendimento de questões subjetivas não devem afastar a incidência do referido princípio tanto quando o réu é reincidente ou possui maus antecedentes;

f) concede a ordem de habeas corpus, restabelecendo a sentença de primeira instância que absolveu o paciente, em virtude da aplicação do princípio da insignificância.

Ayres Britto sustentou que:

a) pediu vista dos autos, pois ficou bem impressionado com as leituras antagônicas do fato-tipo narrado na denúncia;

b) seu grande questionamento é se a situação perpetrada pelo paciente se amolda ou não no tipo penal do furto simples (Art. 155, CP);

c) com base no art. 98, inciso $\mathrm{I}, \mathrm{CF}^{157}$ a Constituição desconsidera a significância penal de tudo o que se encontra abaixo da seara das infrações de menor potencial ofensivo, ou seja, tudo o que se encontrar aquém dessa categoria

\footnotetext{
157، Art. 98, CF: A União, no Distrito Federal e nos Territórios, e os Estados criarão: I - juizados especiais, providos por juízes togados, ou togados e leigos, competentes para a conciliação, o julgamento e a execução de causas cíveis de menor complexidade e infrações penais de menor potencial ofensivo, mediante os procedimentos oral e sumaríssimo, permitidos, nas hipóteses previstas em lei, a transação e o julgamento de recursos por turmas de juízes de primeiro grau."
} 
não terá importância para o âmbito penal;

d) a aplicação do princípio da insignificância traduz a desnecessidade de punição por parte do Estado, pois tais casos comportariam situações de irrelevância penal;

e) devem ser aferidas as diretivas ou os vetores de ponderabilidade que possibilitem ou não a aplicação do princípio da insignificância ${ }^{158}$;

f) cabível é a aplicação do princípio da insignificância, pois a subtração de 2 (duas) gaiolas e pássaros avaliados em $\mathrm{R} \$ 29,00$ (vinte e nove reais) se enquadra à ponderabilidade que permite a aplicação do princípio da insignificância;

g) acompanha o relator na concessão da ordem.

\section{Estrutura do inteiro teor}

\begin{tabular}{|l|l|}
\hline Páginas do inteiro teor & $\begin{array}{l}24 \text { páginas } \\
\text { Ministros Gilmar Mendes (Relator) e } \\
\text { Ayres Britto }\end{array}$ \\
\hline Citação de doutrina & $\begin{array}{l}\text { Ministro Gilmar Mendes: Cezar } \\
\text { Roberto Bitencourt, Rogério Greco e }\end{array}$ \\
\hline
\end{tabular}

${ }^{158} \mathrm{O}$ Ministro Ayres Britto diz que há casos que tais vetores de ponderabilidade indicariam a não aplicação do princípio da insignificância, citando os crimes miliares e os crimes de falsificação de moeda. O ministro cita os acórdãos HC 103.164 que teria sido julgado pelo Plenário e o HC 97.220. Questionamos a citação do HC 103.164, pois não há habeas corpus no STF com essa numeração. Já com relação ao hc 97220 reproduzimos a sua ementa: "Habeas Corpus. Circulação de moeda falsa. Alegação de inexpressividade financeira dos valores impressos nas cédulas falsas. Inaplicabilidade do princípio da insignificância penal ao caso. Norma penal que não se limita a coibir o prejuízo a quem recebeu moeda falsa. Ordem denegada. 1. O princípio da insignificância penal é doutrinariamente versado como vetor interpretativo do fato penalmente típico. Vetor interpretativo que exclui da abrangência do Direito Penal condutas provocadoras de ínfima lesão a bem jurídico alheio. Tal forma de interpretação visa, para além de uma desnecessária carcerização, ao descongestionamento de uma Justiça Penal que se deve ocupar apenas das infrações tão lesivas a bens jurídicos dessa ou daquela pessoa quanto aos interesses societários em geral. 2. A norma criminalizadora da falsificação de moeda tutela a fé pública. Bem jurídico revelador da especial proteção à confiabilidade do "sistema monetário" nacional. Pelo que o valor impresso na moeda falsa não é o critério de análise da relevância, ou da irrelevância da conduta em face das normas penais. 3. Tem-se por violada a fé pública quando a moeda nacional é falsificada seja qual for o valor estampado no papel-moeda. O que impossibilita concluir, no caso, pela inexpressividade da lesão jurídica resultante da conduta do agente. 4. Ordem denegada. Segunda Turma. Relator Ministro Ayres Britto. Dje: 26 de agosto de 2011." Disponível em: $<$ http://redir.stf.jus.br/paginadorpub/paginador.jsp?docTP=AC\&docID $=626704>$. Acesso em: 26 nov. 2013. 


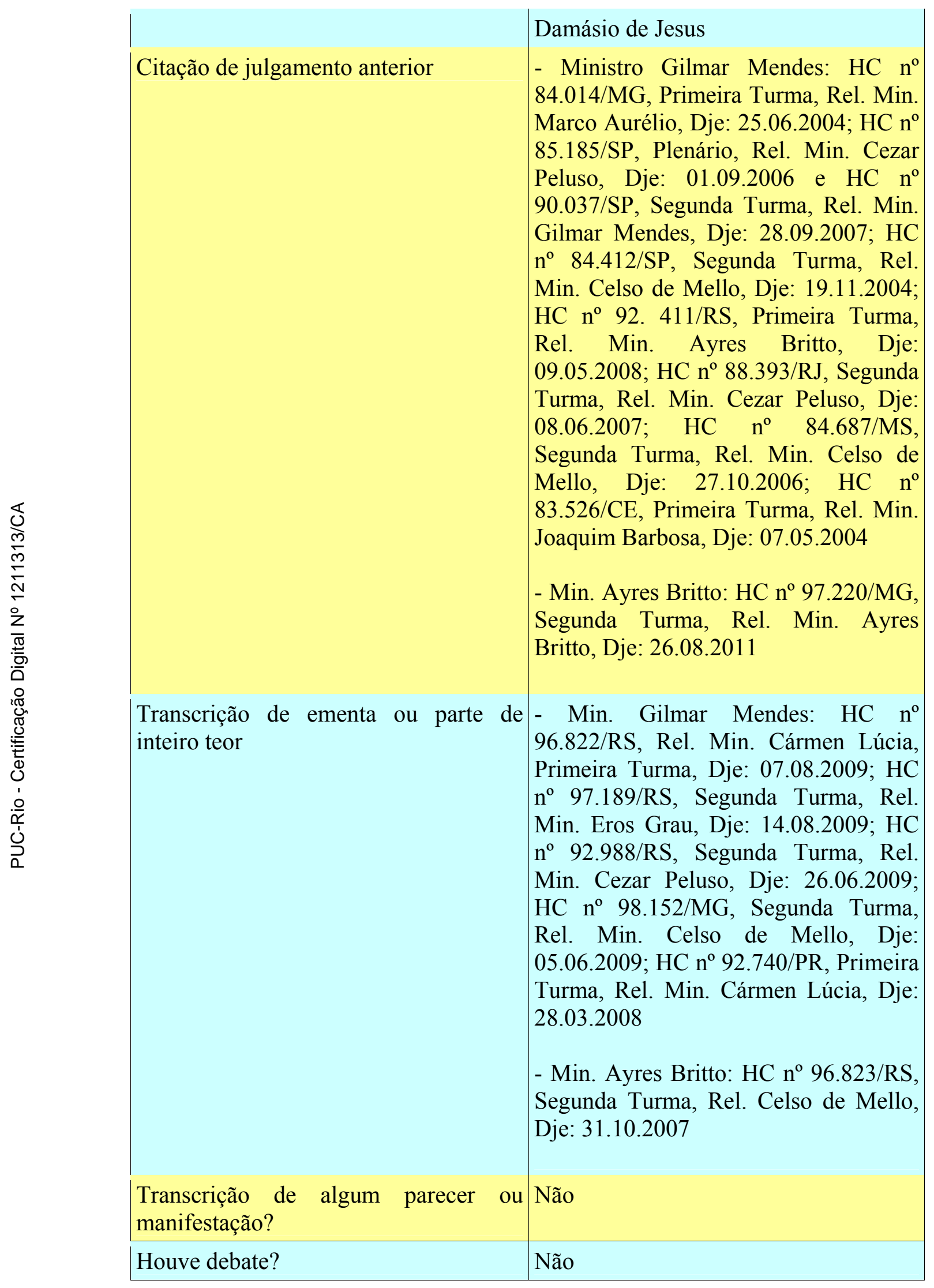


\begin{tabular}{|l|l|} 
Considerações sobre a ementa & $\begin{array}{l}\text { - Não fala que o paciente é reincidente; } \\
\text { - Diz que há precedentes } \\
\text { Houve pedido de vista? }\end{array}$ \\
\hline
\end{tabular} Tabela 06- Estrutura do inteiro teor da "Decisão C"

\section{Quadro resumo dos votos}

\begin{tabular}{|c|c|}
\hline \multicolumn{2}{|c|}{ "Decisão C"- HC n ${ }^{\mathbf{0}}$ 107.184/RS- ${ }^{\mathrm{a}}$ Turma STF } \\
\hline Ministro & Votação \\
\hline Ayres Britto & Aplica-se \\
\hline Celso de Mello & Aplica-se \\
\hline Gilmar Mendes & Aplica-se \\
\hline Joaquim Barbosa & Ausente justificadamente \\
\hline Ricardo Lewandowski & Aplica-se \\
\hline & Decisão unânime pela concessão da \\
ordem
\end{tabular}

Tabela 07- Quadro resumo dos votos da "Decisão C"

\subsection{4}

\section{"Decisão D"- HC nº 109.870/RS ${ }^{159}$}

\section{A. Composição da bancada}

Presentes à sessão os Ministros: Celso de Mello, Gilmar Mendes, Joaquim

\footnotetext{
${ }^{159}$ BRASIL. Supremo Tribunal Federal. Habeas Corpus no 109.870/RS. Segunda Turma. Habeas Corpus. 2. Furto. Bens de pequeno valor (R\$ 35,00). Mínimo grau de lesividade da conduta. 3. Aplicação do princípio da insignificância. Possibilidade. Precedentes. 4. Reincidência. Irrelevância de considerações de ordem subjetiva. 5.Ordem concedida. Paciente: Luciano Vicari. Coator: Superior Tribunal de Justiça. Relator: Ministro Joaquim Barbosa. Brasília, DF. Dje: 22 de maio de 2012. Disponível em: $<$ http://redir.stf.jus.br/paginadorpub/paginador.jsp?docTP=TP\&docID=2024975>. Acesso em: 28 de nov. 2013.
} 
Barbosa (Relator), Ricardo Lewandowski. Ausente justificadamente o Ministro Ayres Britto.

\section{B. Qualificação do caso}

Possibilidade de aplicação ou não do princípio da insignificância a um paciente que subtraiu 1 (um) xampu e 3 (três) condicionadores avaliados em R\$ 35,00 (trinta e cinco reais).

\section{Exposição das decisões}

O paciente foi denunciado pela prática do crime de furto simples (art. 155, caput, $\mathrm{CP}$ ). A denúncia foi rejeitada em razão do princípio da insignificância. $\mathrm{O}$ Ministério Público recorreu em sede de apelação; o Tribunal de Justiça do Rio Grande do Sul deu provimento ao recurso, afastando a aplicação do princípio da insignificância. Em consequência, a Defensoria Pública da União impetrou habeas corpus perante o Superior Tribunal de Justiça. O referido habeas corpus foi negado, pois o paciente apresentava uma vida de delitos, corroborando a sua periculosidade social. Em face da denegação do remédio constitucional, a defesa impetrou o presente habeas corpus no Supremo Tribunal Federal requerendo a aplicação do princípio da insignificância diante do pequeno valor dos bens subtraídos. Frisa-se que houve pedido de liminar objetivando a suspensão cautelar do processo crime, que foi deferido pelo Ministro Celso de Mello.

O julgamento do $\mathrm{HC}^{\circ}$ 109.870/RS foi realizado no dia 08.11.2011. Há a íntegra dos votos dos Ministros Joaquim Barbosa, Gilmar Mendes e Ricardo Lewandowski. Em virtude do empate na votação, deferiu-se a ordem de habeas corpus com base no art. 150, $\S 3^{\circ}$, RISTF ${ }^{160}$.

\footnotetext{
${ }^{160}$ Art. 150, $\S 3^{\circ}$ RISTF: "Nos habeas corpus e em matéria criminal, exceto o recurso
} extraordinário, havendo empate, prevalecerá a decisão mais favorável ao paciente ou réu". 
Joaquim Barbosa destacou que:

a) não entende estarem presentes os requisitos que autorizam a aplicação do princípio da insignificância;

b) o baixo valor monetário envolvido na conduta criminosa não é o único requisito necessário para a aplicação do princípio da insignificância, pois devem ser analisados outros vetores como a reprovabilidade do comportamento e as consequências do crime;

c) o paciente é reincidente e possuidor de maus antecedentes, constando nos autos relatório com 20 (vinte) páginas de registros criminais dos mais diversos crimes (roubo, furto, estelionato, receptação, posse de drogas e violência doméstica);

d) a reincidência e a prática de condutas delituosas é um demonstrativo de que o transgressor despreza o ordenamento jurídico no âmbito penal;

e) o criminoso habitual não pode merecer o mesmo tratamento do indivíduo que em uma ocasião apenas pratica algum delito, conforme decidido no $\mathrm{HC} 100.240 / \mathrm{RJ}^{161}$.

f) há precedente do Supremo Tribunal Federal em questões como a do caso em análise, transcrevendo parte da fundamentação do HC 97.772/RS, em que nessa oportunidade, a Primeira Turma denegou a concessão de habeas corpus a um paciente que era reincidente;

g) o criminoso, segundo manifestação do Ministério Público Federal, se valeu de meios ardilosos para tentar lograr êxito em sua empreitada criminosa, pois enquanto furtava os produtos, colocava outros produtos dentro de uma cesta de supermercados, dirigiu-se ao caixa do supermercado para registrá-los, informando que estava sem dinheiro, mas iria até sua casa buscá-lo;

h) denega a ordem de habeas corpus.

Em sequência, temos o voto de Lewandowski que denega a ordem de habeas corpus. Afirma, conforme o voto do Relator, que o paciente possui uma ampla ficha criminal e além do transgressor ter lançado mão de meios astuciosos

161 STF, HC n ${ }^{\text {o }}$ 100.240/RJ, Rel. Min. Joaquim Barbosa, Dje: 02.03.2011. 
na efetivação de seu ato, tentando enganar os funcionários do supermercado. Tais características demonstram uma personalidade voltada para o crime.

Por último, há a íntegra do voto do Ministro Mendes que discorda tanto de Barbosa quanto de Lewandowski apontando que:

a) entende ser uma questão em que se deve analisar a tipicidade de forma objetiva;

b) a Segunda Turma do STF tem excepcionado a aplicação do princípio da insignificância em crimes que envolvem, por exemplo, ameaça, violência, rompimento de obstáculos, concurso de menores;

c) o presente caso não se enquadra em nenhuma dessas situações;

d) há precedentes da Segunda Turma que apontam que em casos análogos ao do presente habeas corpus, deve-se examinar a tipicidade de forma objetiva;

e) com base em alguns acórdãos, por exemplo o $\mathrm{HC} \mathrm{n}^{\circ}$ 93.393/RS (“Decisão A") e o HC n ${ }^{\circ}$ 106.510/MG ("Decisão F"), confirma o posicionamento da Segunda Turma no sentido de desconsiderar os aspectos de ordem subjetiva;

f) cita 5 (cinco) habeas corpus que comprovam que a jurisprudência do STF tem sido no sentido que a "insignificância da infração penal, que tenha o condão de descaracterizar materialmente o tipo, impõe o trancamento da ação penal por falta de justa causa" ${ }^{, 162}$.

\section{Estrutura do inteiro teor}

\begin{tabular}{|c|c|}
\hline Páginas do inteiro teor & 14 páginas \\
\hline Transcrição integral do voto & $\begin{array}{l}\text { Ministros Joaquim Barbosa (Relator), } \\
\text { Ricardo Lewandowski, Gilmar Mendes }\end{array}$ \\
\hline Citação de doutrina & Não \\
\hline Citação de julgamento anterior & $\begin{array}{l}\text { - Min. Joaquim Barbosa: HC } \mathrm{n}^{\mathrm{o}} \\
\text { 100.240/RJ, Segunda Turma, Rel. Min. } \\
\text { Joaquim Barbosa, Dje: 07.12.2010 }\end{array}$ \\
\hline
\end{tabular}

${ }^{162}$ STF, HC n ${ }^{\circ}$ 109.870/RS. Rel. Min. Joaquim Barbosa, Dje: 22.05.2012. 


\begin{tabular}{|c|c|}
\hline \multirow{3}{*}{$\begin{array}{l}\text { Transcrição de ementa ou parte de } \\
\text { inteiro teor }\end{array}$} & $\begin{array}{l}\text { - Min. Gilmar Mendes: HC } \mathrm{n}^{\circ} 92 . \\
\text { 411/RS, Primeira Turma, Rel. Min. } \\
\text { Ayres Britto, Dje: 09.05.2008; HC }{ }^{\circ} \\
\text { 88.393/RJ, Segunda Turma, Rel. Min. } \\
\text { Cezar Peluso, Dje: 08.06.2007; HC no } \\
\text { 84.687/MS, Segunda Turma, Rel. Min. } \\
\text { Celso de Mello, Dje: 27.10.2006; HC } \\
\text { n }^{\circ} \text { 84.412/SP, Segunda Turma, Dje: } \\
\text { 19.11.2004; HC no 83.526/CE, Primeira } \\
\text { Turma, Rel. Min. Joaquim Barbosa, } \\
\text { Dje: 07.05.2004 }\end{array}$ \\
\hline & $\begin{array}{l}\text { - Min. Joaquim Barbosa: HC } \mathrm{n}^{\mathrm{o}} \\
\text { 97.772/RS, Primeira Turma, Rel. Min. } \\
\text { Cármen Lúcia, Dje: 20.11.2009 }\end{array}$ \\
\hline & $\begin{array}{l}\text { - Min. Gilmar Mendes: HC } \mathrm{n}^{\circ} \\
\text { 109.783/MG, Segunda Turma, Rel. } \\
\text { Min. Gilmar Mendes, Dje: 06.09.2011; } \\
\text { HC no 93.393/RS, Segunda Turma, } \\
\text { Min. Cezar Peluso, Dje: 15.05.2009; } \\
\text { HC no 106.510/MG, Segunda Turma, } \\
\text { Rel. Min. Joaquim Barbosa, Dje: } \\
\text { 13.06.2011 }\end{array}$ \\
\hline $\begin{array}{l}\text { Transcrição de algum parecer ou } \\
\text { manifestação? }\end{array}$ & $\begin{array}{l}\text { - Voto Min. Joaquim Barbosa: } \\
\text { manifestação do Ministério Público } \\
\text { Federal }\end{array}$ \\
\hline Houve debate? & Não \\
\hline Considerações sobre a ementa & $\begin{array}{l}\text { - Consta a reincidência do paciente } \\
\text { - Diz que há precedentes }\end{array}$ \\
\hline Houve pedido de vista? & Não \\
\hline
\end{tabular}

\section{E. Quadro resumo dos votos}

\begin{tabular}{|l|c|}
\hline \multicolumn{2}{|c|}{ "Decisão D"- $\mathrm{HC} \mathrm{n}^{\text {o }} 109.870 / \mathrm{RS}-2^{\mathrm{a}}$ Turma STF } \\
\hline Ministro & Votação \\
\hline Ayres Britto & Ausente justificadamente \\
\hline
\end{tabular}




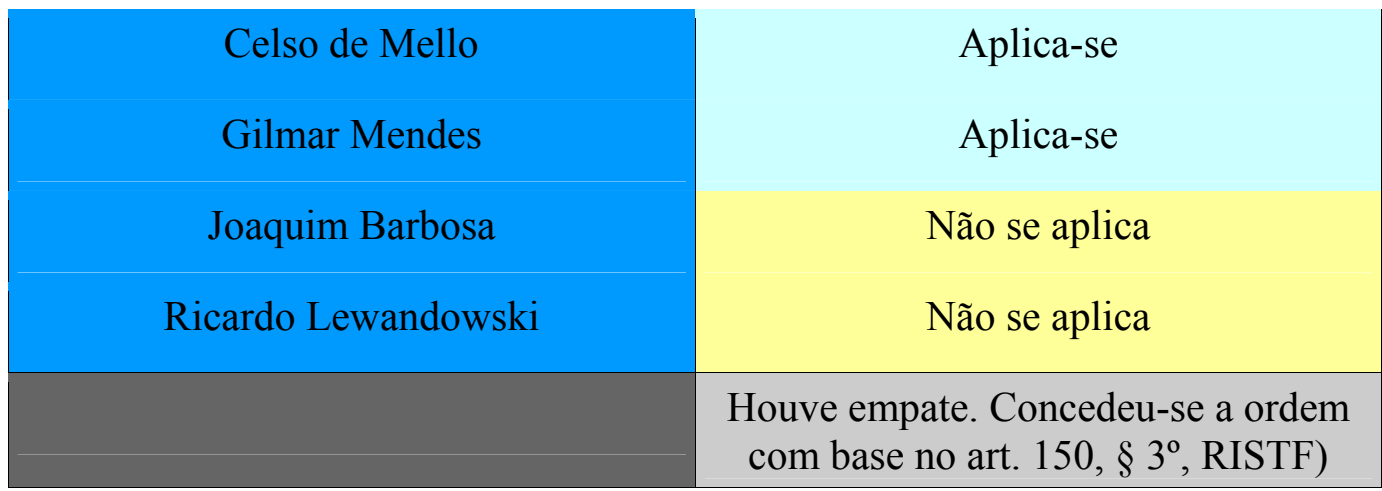

Tabela 09- Quadro resumo dos votos da "Decisão D"

\section{1 .5}

\section{"Decisão E"- HC n 118.089/MG ${ }^{163}$}

\section{A. Composição da bancada}

Presentes à sessão os Ministros Cármen Lúcia (Relatora), Gilmar Mendes

e Teori Zavascki. Ausentes justificadamente os Ministros Celso de Mello e

Ricardo Lewandowski.

\footnotetext{
${ }^{163}$ BRASIL. Supremo Tribunal Federal. Habeas Corpus $n^{\circ}$ 118.089/MG. Segunda Turma. Habeas Corpus. Furto. Pretensão de aplicação do princípio da insignificância. Inviabilidade. Paciente reincidente. Precedentes. Ordem denegada. 1. A tipicidade penal não pode ser percebida como o exercício de mera adequação do fato concreto à norma abstrata. Além da correspondência formal, a configuração da tipicidade demandaria uma análise materialmente valorativa das circunstâncias do caso concreto, para verificar a ocorrência de alguma lesão grave, contundente e penalmente relevante do bem jurídico tutelado. 2. Reincidência do Paciente assentada nas instâncias antecedentes. $\mathrm{O}$ criminoso contumaz, mesmo que pratique crimes de pequena monta, não pode ser tratado pelo sistema penal como se tivesse praticado condutas irrelevantes, pois crimes considerados ínfimos, quando analisados isoladamente, mas relevantes quando em conjunto, seriam transformados pelo infrator em verdadeiro meio de vida. 3. O princípio da insignificância não pode ser acolhido para resguardar e legitimar constantes condutas desvirtuadas, mas para impedir que desvios de conduta ínfimos, isolados, sejam sancionados pelo direito penal, fazendose justiça no caso concreto. Comportamentos contrários à lei penal, mesmo que insignificantes, quando constantes, devido à sua reprovabilidade, perdem a característica da bagatela e devem se submeter ao direito penal. 4. Ordem denegada. Paciente: Reinaldo Galdino Dias. Coator: Superior Tribunal de Justiça. Relatora: Ministra Cármen Lúcia. Brasília, DF. Dje: 24 de outubro de 2013. Disponível em: $<$ http://redir.stf.jus.br/paginadorpub/paginador.jsp?docTP=TP\&docID=4743388>. Acessado em: 28 nov. 2013.
} 


\section{B. Qualificação do caso}

Possibilidade de aplicação ou não do princípio da insignificância a um paciente que furtou uma cédula de $\mathrm{R} \$ 50,00$ (cinquenta reais) e um maço de cigarros de uma padaria, que totalizaram $\mathrm{R} \$ 67,00$ (sessenta e sete reais).

\section{Exposição das decisões}

Trata-se de uma denúncia contra um paciente pela prática de furto (art. 155 c/c art. 61, I ambos do CP) de uma cédula de $\mathrm{R} \$ 50,00$ (cinquenta reais) e um maço de cigarros, avaliados em $\mathrm{R} \$ 67,00$ (sessenta e sete reais). O crime ocorreu em uma padaria quando o dono se descuidou, por um momento, de vigiar a caixa registradora. Em primeira instância o paciente foi condenado à pena de dois anos de reclusão e vinte dias-multa. A defesa apelou e a Primeira Câmara Criminal do Tribunal de Justiça de Minas Gerais deu provimento ao recurso absolvendo Reinaldo Galdino Dias. O Ministério Público ingressou com Recurso Especial perante o STJ que por meio de decisão monocrática deu provimento ao recurso, afastando a incidência do princípio da insignificância, uma vez que se tratava de paciente reincidente. Logo após, a defesa interpôs agravo regimental, no entanto o STJ negou provimento ao recurso. Em razão disso, impetrou-se habeas corpus perante o STF.

O julgamento do $\mathrm{HC}^{\mathrm{o}}$ 118.089/MG deu-se no dia 08.10.2013. O inteiro teor é composto, unicamente, da íntegra do voto da Ministra Relatora Cármen Lúcia. Por unanimidade dos votos, denegou-se a ordem.

Cármen Lúcia denega a ordem, sustentando que:

a) a análise da tipicidade penal não consiste apenas na adequação do fato concreto à norma jurídica, sendo necessário também realizar uma análise materialmente valorativa das circunstâncias do caso concreto;

b) o paciente é reincidente, não sendo primário na prática delitiva;

c) afirma que a decisão do agravo regimental do STJ ao manter a sentença 
condenatória estaria "em harmonia com a jurisprudência do Supremo Tribunal Federal"164;

d) o agente que pratica crimes reiteradamente, mesmo que sejam crimes de pequena monta, não pode o Direito Penal ignorá-los, pois situações como essa demonstram um indivíduo que faz do crime um modo de vida.

\section{Estrutura do inteiro teor}

\begin{tabular}{|c|c|}
\hline Páginas do inteiro teor & 12 páginas \\
\hline Transcrição integral do voto & Ministra Cármen Lúcia (Relatora) \\
\hline Citação de doutrina & Não \\
\hline Citação de julgamento anterior & Não \\
\hline $\begin{array}{l}\text { Transcrição de ementa ou parte de } \\
\text { inteiro teor }\end{array}$ & $\begin{array}{l}\text { - HC n } 108.403 / \mathrm{RS} \text {, Primeira Turma, } \\
\text { Rel. Min. Luiz Fux, Dje: 18.03.2013; } \\
\text { HC no 111.608/RS, Segunda Turma, } \\
\text { Rel. Min. Ricardo Lewandowski, Dje: } \\
\text { 20.09.2012; HC n }{ }^{\circ} \text { 107.138/RS, } \\
\text { Primeira Turma, Rel. Min. Ricardo } \\
\text { Lewandowski, Dje: } 30.05 .2011\end{array}$ \\
\hline $\begin{array}{l}\text { Transcrição de algum parecer ou } \\
\text { manifestação? }\end{array}$ & $\begin{array}{l}\text { Parecer da Procuradoria-Geral da } \\
\text { República }\end{array}$ \\
\hline Houve debate? & Não \\
\hline Considerações sobre a ementa & $\begin{array}{l}\text { - Fala que o paciente é reincidente; } \\
\text { - Diz que há precedentes. }\end{array}$ \\
\hline Houve pedido de vista? & Não \\
\hline
\end{tabular}

Tabela 10- Estrutura do inteiro teor da "Decisão E"

\section{E. Quadro resumo dos votos}

\footnotetext{
${ }^{164}$ Com base nas seguintes decisões: HC 108.403/RS, Rel. Min. Luiz Fux, Dje: 06.03.12; HC n ${ }^{\circ}$ 111.608/RS, Rel. Min. Rel. Ricardo Lewandowski, Dje: 20.09.2012; HC n 107.138/RS, Rel. Min. Ricardo Lewandowski, Dje: 30.05.2011.
} 


\begin{tabular}{|c|c|}
\hline \multicolumn{2}{|c|}{ “Decisão E”- HC nº 118.089/MG- 2a Turma STF } \\
\hline Ministro & Votação \\
\hline Cármen Lúcia & Não se aplica \\
\hline Celso de Mello & Ausente justificadamente \\
\hline Gilmar Mendes & Não se aplica \\
\hline Ricardo Lewandowski & Ausente justificadamente \\
\hline Teori Zavascki & Não se aplica \\
\hline & $\begin{array}{c}\text { Decisão unânime pela denegação da } \\
\text { ordem }\end{array}$ \\
\hline
\end{tabular}

Tabela 11- Quadro resumo dos votos da "Decisão E"

\section{2 \\ Habeas corpus em casos de furto simples tentado}

Foi selecionado um grupo de 4 (quatro) habeas corpus julgados pela Segunda Turma do Supremo: HC n ${ }^{\circ} 106.510 / \mathrm{MG}, \mathrm{HC} \mathrm{n}^{\mathrm{o}} 108.872 / \mathrm{RS}, \mathrm{HC} \mathrm{n}^{\mathrm{o}}$ 114.060/MG e $\mathrm{HC} \mathrm{n}{ }^{\circ} 113.782 / \mathrm{RS}$, que serão chamados, respectivamente, de decisões "F", "G", "H" e "I". As decisões tratam de casos parecidos em que pacientes reincidentes praticaram furto simples tentado ${ }^{165}$ e requereram a aplicação do princípio da insignificância perante o STF.

As 4 (quatro) decisões tiveram resultados completamente diferentes, pois no $\mathrm{HC} \mathrm{n}^{\circ}$ 106.510/MG houve empate, mas com base no art. 150, $\S 3^{\circ}$ RISTF concedeu-se a ordem, no $\mathrm{HC} \mathrm{n}^{\mathrm{o}} 108.872 / \mathrm{RS}$ foi unânime pela concessão da ordem, no $\mathrm{HC}^{\mathrm{o}}$ 114.060/MG houve maioria de votos pela concessão da ordem e no HC n ${ }^{0}$ 113.782/RS foi unânime pela denegação da ordem. No "Quadro 04" constata-se isso facilmente.

Além de a Segunda Turma não possuir um posicionamento definido e

\footnotetext{
${ }^{165}$ A única agravante considerada nessa pesquisa é a reincidência. Os casos selecionados não possuem qualquer outro tipo de agravante, ou qualquer espécie de privilégio, qualificadora, atenuante, concurso de crimes e concurso de pessoas.
} 
claro com relação à questão da aplicação do princípio da bagatela em casos de furto simples tentado a pacientes reincidentes, verifica-se que tanto Ayres Britto quanto Joaquim Barbosa divergiram em seus votos. Em casos parecidos votaram de modo diferente, sem oferecer ao leitor qualquer argumentação de que aquele caso seria tratado de forma diferente, pois se tratava de um caso em que há overruling, overriding, distinguishing ou transformation.

\subsection{1 \\ "Decisão F"- HC nº 106.510/MG ${ }^{166}$}

\section{A. Composição da bancada}

Presentes à sessão os Ministros: Ayres de Britto, Celso de Mello, Ellen Gracie, Gilmar Mendes, Joaquim Barbosa (Relator).Ausentes, justificadamente, a Ministra Ellen Gracie.

166 BRASIL. Supremo Tribunal Federal. Habeas Corpus $\mathrm{n}^{\mathrm{o}}$ 106.510/MG. Segunda Turma. Princípio da insignificância - identificação dos vetores cuja presença legitima o reconhecimento desse postulado de política criminal - conseqüente descaracterização da tipicidade penal em seu aspecto material - delito de furto simples, em sua modalidade tentada (cp, art. 155, caput, c/c o art. 14, II) - "res furtiva" no valor (ínfimo) de R\$ 70,00 - doutrina - considerações em torno da jurisprudência do stf - "habeas corpus" deferido. O princípio da insignificância qualifica-se como fator de descaracterização material da tipicidade penal. - o princípio da insignificância - que deve ser analisado em conexão com os postulados da fragmentariedade e da intervenção mínima do estado em matéria penal - tem o sentido de excluir ou de afastar a própria tipicidade penal, examinada na perspectiva de seu caráter material. Doutrina. Tal postulado - que considera necessária, na aferição do relevo material da tipicidade penal, a presença de certos vetores, tais como (a) a mínima ofensividade da conduta do agente, (b) a nenhuma periculosidade social da ação, (c) o reduzidíssimo grau de reprovabilidade do comportamento e (d) a inexpressividade da lesão jurídica provocada - apoiou-se, em seu processo de formulação teórica, no reconhecimento de que o caráter subsidiário do sistema penal reclama e impõe, em função dos próprios objetivos por ele visados, a intervenção mínima do poder público. O postulado da insignificância e a função do direito penal: "de minimis, non curat praetor". - O sistema jurídico há de considerar a relevantíssima circunstância de que a privação da liberdade e a restrição de direitos do indivíduo somente se justificam quando estritamente necessárias à própria proteção das pessoas, da sociedade e de outros bens jurídicos que lhes sejam essenciais, notadamente naqueles casos em que os valores penalmente tutelados se exponham a dano, efetivo ou potencial, impregnado de significativa lesividade. Paciente: José Roberto Ferreira. Coator: Relator do Resp no 1193326 do Superior Tribunal de Justiça. Brasília, DF, Dje: 13 de junho de 2011. Disponível em: $<$ http://redir.stf.jus.br/paginadorpub/paginador.jsp?docTP=TP\&docID=1231194>. Acesso em: 14 de nov. de 2013. 


\section{B. Qualificação do caso}

O caso trata da possibilidade de aplicação ou não do princípio da insignificância a um paciente que praticou furto tentado de uma máquina de cortar cabelo, avaliada em R \$70,00 (setenta reais). No caso em questão, o delito não se consumou, pois o réu foi abordado por seguranças na saída do estabelecimento que o impediram de consumar o furto.

\section{Exposição das decisões}

Trata-se de um caso em que o paciente foi condenado por tentativa de furto (art. 155, CP, c/c art. 14, II, CP), em primeira instância a pena de 10 (dez) meses de reclusão em regime semiaberto. Houve apelação e, consequentemente, a reforma da sentença no sentido da absolvição do paciente. No entanto, o Ministério Público recorreu em sede de Recurso Especial ao STJ requerendo novamente sua condenação. O STJ deu provimento ao recurso para restabelecer a sentença de primeiro grau, uma vez que é pacífico o entendimento nessa Corte de que o sistema de vigilância em estabelecimento comercial, mesmo que dificulte a prática de furtos em seu interior, não é capaz de impedir a ocorrência de fatos delituosos. Diante dessa decisão, a Defensoria Pública da União impetrou habeas corpus perante o STF, requerendo o reconhecimento da atipicidade da conduta do paciente.

O julgamento ocorreu no dia 22.03.2011 tendo como relator o Ministro Joaquim Barbosa. O inteiro teor é composto pelos votos dos Ministros Joaquim Barbosa, Ayres Britto, Celso de Mello e Gilmar Mendes. No julgamento houve empate. Em razão do empate, a ordem foi deferida ao paciente.

De modo didático, considerando a extensão do inteiro teor, a decisão será dividida em três blocos: $1^{\mathrm{o}}$ : composto pelos votos de Joaquim Barbosa, Ayres Britto e Celso de Mello; $2^{\circ}$ : parte em que há aditamento dos votos referidos; $3^{\circ}$ : 
seção formada pelo voto de Gilmar Mendes.

Iniciando o primeiro bloco, destaca-se a partir do voto de Barbosa que:

a) entende não ser um caso que possibilite a aplicação do princípio da insignificância;

b) na aplicação do princípio da insignificância, devem-se verificar outros requisitos além da quantia envolvida no fato delituoso;

c) no caso em tela, o paciente é reincidente e possui maus antecedentes, além de ter sido condenado por crimes semelhantes; esse fato constitui razão para se afastar o princípio da insignificância, tendo em vista que tais fatos reiteram o desprezo do réu com as normas jurídico-penais;

d) em casos assim, tem-se a figura do criminoso habitual, fazendo referência ao $\mathrm{HC} \mathrm{n}^{\circ}$ 100.240/RJ;

e) há precedente da Corte no sentido de que condutas desse porte não devem ser desconsideradas pelo sistema penal; o ministro transcreve parte do HC $n^{\text {o }}$ 97.772/RS, $1^{\text {a }}$ Turma, Rel. Ministra Carmen Lúcia, Dje 20.11.2009 ${ }^{167}$;

f) vota pela denegação da ordem.

Já Ayres Britto acompanha o Relator, ressaltando que ele é inclinado à aplicação do princípio da insignificância. No entanto, o caso trata de um paciente acostumado com a delituosidade. Por isso, vota no sentido da denegação da ordem de habeas corpus.

Por sua vez, Celso de Mello, em um extenso voto de 10 (dez) páginas , cita 7 (sete) acórdãos e transcreve outros 7 (sete), demonstrando que se deve aplicar o princípio da insignificância, pois:

a) estariam presentes os requisitos como: I) a mínima ofensividade da conduta, II) nenhuma periculosidade social da ação, III) o reduzidíssimo grau de

\footnotetext{
${ }^{167}$ Destaca-se o seguinte trecho do $\mathrm{HC} \mathrm{n}^{\circ}$ 97.772/RS citado pelo Ministro Joaquim Barbosa: "O criminoso contumaz, mesmo que pratique crimes de pequena monta, não pode ser tratado pelo sistema penal como se tivesse praticado condutas irrelevantes, pois, crimes considerados ínfimos, quando analisados isoladamente, mas relevantes quando em conjunto, seriam transformados pelo infrator em verdadeiro meio de vida (...) O princípio da insignificância não foi estruturado para resguardar e legitimar constantes condutas desvirtuadas, mas para impedir que desvios de conduta ínfimos, isolados sejam sancionados pelo direito penal, fazendo-se justiça no caso concreto. (...) Tenho, pois, que o criminoso reincidente apresenta comportamento reprovável que não pode ficar imune ao direito penal e sua conduta deve ser considerada materialmente típica."
} 
reprovabilidade do comportamento jurídico e IV) a inexpressividade da lesão jurídica provocada;

b) defende a análise do princípio da insignificância com os postulados da fragmentariedade e da intervenção mínima do Estado em matéria penal;

c) enfatiza que se trata de uma subtração na modalidade tentada e a o objeto furtado foi avaliado "no valor de $\mathrm{R} \$ 70,00$, equivalia à época do delito (outubro de 2008), a $16,78 \%$ do valor do salário mínimo então vigente (R\$415,00), correspondendo, atualmente a $12,84 \%$ do salário mínimo ora em vigor em nosso País";

d) concede a ordem de habeas corpus.

Iniciando o exame do segundo bloco, frisa-se que o Ministro Joaquim Barbosa reformula e concede de ofício no tocante ao regime prisional, convertendo-o em regime aberto.

Ayres Britto ressalta que:

a) o princípio da insignificância é algo não previsto em lei e é a jurisprudência que tem abraçado essa proposta;

b) o reconhecimento desse princípio não pode significar um estímulo à reincidência;

c) trata-se de um réu habituado à delituosidade;

d) é preocupante o fato de a decisão poder se uma ponte para a reiteração de condutas criminosas;

e) propõe que o regime penitenciário de cumprimento de pena seja flexibilizado ou substituído por uma pena restritiva de direitos.

Ambos os Ministros Ayres Britto e Celso de Mello perguntam se a reincidência estaria comprovada nos autos. Joaquim Barbosa diz: "não sei se há decisão. A sentença fala em reincidência".

Celso de Mello complementa que: "não se tornará possível a conversão em pena restritiva de direitos se o réu for reincidente específico em crime doloso (art. 44, inc II, CP $)^{168}$. Após isso, os Ministros Celso de Mello, Ayres Britto e Joaquim

\footnotetext{
168 "Art. 44, CP: As penas restritivas de direitos são autônomas e substituem as privativas de
} liberdade, quando: II - o réu não for reincidente em crime doloso.” 
Barbosa resolvem pelo regime aberto, impondo ao paciente condenado a pena de 10 (dez) meses de reclusão.

O terceiro bloco do acórdão consiste no voto de Gilmar Mendes sustentando que a conduta seria atípica. Entende que essa questão está sendo construída e que no futuro será apresentada de um modo consonante. O ministro defere a ordem.

\section{Estrutura do inteiro teor}

\begin{tabular}{|c|c|}
\hline Páginas do inteiro teor & 23 páginas \\
\hline Transcrição integral do voto & $\begin{array}{l}\text { Ministros Joaquim Barbosa (Relator), } \\
\text { Celso de Mello, Gilmar Mendes e } \\
\text { Ayres Britto. }\end{array}$ \\
\hline Citação de doutrina & $\begin{array}{l}\text { - Min. Celso de Mello: Cezar Roberto } \\
\text { Bitencourt, Damásio de Jesus, } \\
\text { Maurício Antônio Ribeiro Lopes, } \\
\text { Edilson Mougenot Bonfim, Fernando } \\
\text { Capez e René Ariel Dotti. }\end{array}$ \\
\hline Citação de julgamento anterior & 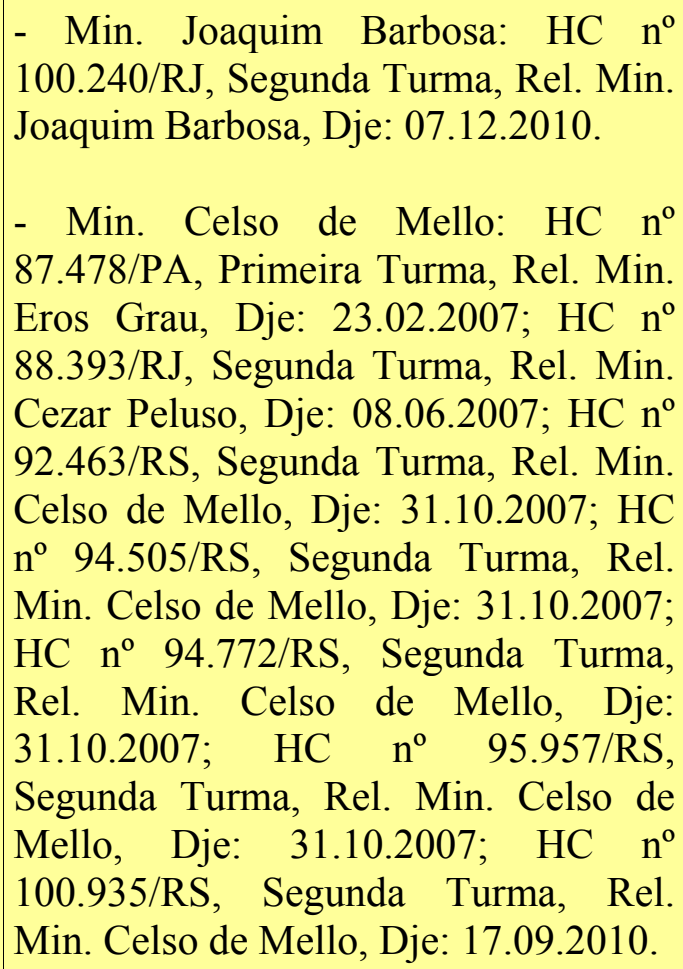 \\
\hline
\end{tabular}




\begin{tabular}{|c|c|}
\hline $\begin{array}{l}\text { Transcrição de ementa ou parte de } \\
\text { inteiro teor }\end{array}$ & $\begin{array}{l}\text { - Min. Joaquim Barbosa: HC no } \\
\text { 97.772/RS, Primeira Turma, Rel. Min. } \\
\text { Cármen Lúcia, Dje: 20.11.2009. }\end{array}$ \\
\hline & $\begin{array}{l}\text { - Min. Celso de Mello: HC } \text { n }^{\circ} \\
\text { 84.687/MS, Segunda Turma, Rel. Min. } \\
\text { Celso de Mello, Dj: 27.10.2006; HC n } \\
\text { 83.526/CE, Primeira Turma, Rel. Min. } \\
\text { Joaquim Barbosa, DJ: 07.05.2004; HC } \\
\text { n }^{\circ} \text { 87.478/PA, Primeira Turma, Rel. } \\
\text { Min. Eros Grau, DJ: 23.02.2007; HC n } \\
\text { 88.393/RJ, Segunda Turma, Rel. Min. } \\
\text { Cezar Peluso, DJ: 08.06.2007; RHC n } \\
\text { 89.624/RS, Primeira Turma, Rel. Min. } \\
\text { Cármen Lúcia, DJ: 07.12.2006; HC n } \\
\text { 92.463/RS, Segunda Turma, Rel. Min. } \\
\text { Celso de Mello, DJ: } 31.10 .2007\end{array}$ \\
\hline $\begin{array}{l}\text { Transcrição de algum parecer ou } \\
\text { manifestação? }\end{array}$ & $\begin{array}{l}\text { - Min. Joaquim Barbosa: transcrição de } \\
\text { passagem da manifestação do } \\
\text { Ministério Público Federal }\end{array}$ \\
\hline Houve debate? & - Não ${ }^{169}$ \\
\hline Considerações sobre a ementa & $\begin{array}{l}\text { - Não fala que o paciente é reincidente } \\
\text { - Propõe considerações em torno da } \\
\text { jurisprudência do STF }\end{array}$ \\
\hline Houve pedido de vista? & Não \\
\hline
\end{tabular}

Tabela 12- Estrutura do inteiro teor da "Decisão F"

\section{E. Quadro resumo dos votos}

\begin{tabular}{|c|c|}
\hline \multicolumn{2}{|c|}{ “Decisão F”- HC n ${ }^{\text {o }} 106.510 / \mathrm{MG}-2^{\mathrm{a}}$ Turma STF } \\
\hline Ministro & Votação \\
\hline Ayres Britto & Não se aplica \\
Celso de Mello & Aplica-se \\
\hline
\end{tabular}

\footnotetext{
169 Ressalta-se que houve um breve diálogo entre os ministros para se definir o regime de cumprimento de pena do paciente. Desconsiderou-se esse debate, pois em nada acrescentou na resolução da questão da aplicação do princípio da insignificância.
} 


\begin{tabular}{|c|c|}
\hline Ellen Gracie & Ausente justificadamente \\
\hline Gilmar Mendes & Aplica-se \\
\hline Joaquim Barbosa & Não se aplica \\
& $\begin{array}{c}\text { Houve empate na votação. E por este } \\
\text { motivo, deferiu-se a ordem }\end{array}$ \\
\hline
\end{tabular}

Tabela 13- Quadro resumo da "Decisão F"

\section{2 .2 \\ "Decisão G"- HC no 108.872/RS ${ }^{170}$}

\section{A. Composição da bancada}

Presentes à sessão os Ministros Ayres Britto, Celso de Mello, Gilmar Mendes (Relator). Ausentes justificadamente os Ministros Joaquim Barbosa e Ricardo Lewandowski.

\section{B. Qualificação do caso}

O caso trata da possibilidade de aplicação ou não do princípio da insignificância a um paciente que tentou subtrair um cabo de cobre de um pararaios. O material furtado foi avaliado em $\mathrm{R} \$ 100,00$ (cem reais). O crime não se consumou por circunstâncias alheias à vontade do agente, visto que sua conduta foi flagrada e interrompida por funcionários do posto de combustível.

\footnotetext{
${ }^{170}$ BRASIL. Supremo Tribunal Federal. Habeas Corpus n ${ }^{\circ}$ 108.872/RS. Segunda Turma. Habeas Corpus. 2. Tentativa de furto. Bem de pequeno valor (R\$100,00). Mínimo grau de lesividade da conduta. 3. Aplicação do princípio da insignificância. Possibilidade. Precedentes. 4. Reincidência. Irrelevância de considerações de ordem subjetiva. 5.Ordem concedida. Paciente: Jesus André Dutra Padua. Coator: Superior Tribunal de Justiça. Brasília, DF. Dje: 23 de setembro de 2011. Disponível em: $<$ http://redir.stf.jus.br/paginadorpub/paginador.jsp?docTP=TP\&docID=1467205>. Acesso em: 18 nov. 2014.
} 


\section{Exposição das decisões}

O paciente foi denunciado pela prática de furto tentado com agravante de reincidência (art. 155, caput, $\mathrm{CP}$ c/c art. 14, II e art. 61, I, CP), tendo sido absolvido em primeira instância com base no princípio da insignificância. $\mathrm{O}$ Ministério Público recorreu em sede de apelação perante o Tribunal de Justiça do Rio Grande do Sul. O Tribunal reconheceu que o valor do bem subtraído representaria aproximadamente $20 \%$ (vinte por cento) do salário mínimo da época ( $\mathrm{R} \$ 510,00)$ e que se tratava de um "réu triplamente reincidente, que registra outro processo em andamento, pela prática do crime de furto qualificado tentado", apresentando, assim, condições subjetivas que não indicariam a aplicação do princípio da insignificância. A Oitava Câmara do TJ/RS, por unanimidade, deu provimento à apelação do Ministério Público. Em seguida, a defesa impetrou habeas corpus perante o Superior Tribunal de Justiça que denegou a ordem. Em decorrência dessa decisão, a defesa impetrou o presente habeas corpus perante o STF.

O julgamento aconteceu no dia 06.09.2011 e teve como Relator o Ministro Gilmar Mendes. O inteiro teor é composto apenas da transcrição do voto integral do Ministro Relator Gilmar Mendes. A decisão foi unânime no sentido da concessão da ordem.

Gilmar Mendes sustenta que:

a) o direito penal só deve se preocupar com condutas que sejam socialmente relevantes e que venham a ofender bens jurídicos que possuam maior relevância na vida social, não devendo se ocupar de condutas insignificantes;

b) não há motivo para se movimentar a máquina estatal em um caso em que o bem seria avaliado em $\mathrm{R} \$ 100,00$ (cem reais);

c) no caso, deve-se afastar a condição de reincidente do réu, pois isto não figura como um empecilho na aplicação do princípio da bagatela;

d) apenas se deve preocupar com os aspectos objetivos do fato;

e) ratifica seu posicionamento com duas decisões: "Decisão $\mathrm{A}^{\prime}-\mathrm{HC} \mathrm{n}^{\mathrm{o}}$ 93.393/MG e "Decisão F"- HC nº 106.510/MG. 


\section{Estrutura do inteiro teor}

\begin{tabular}{|c|c|}
\hline Páginas do inteiro teor & 13 páginas \\
\hline Transcrição integral do voto & Ministro Gilmar Mendes (Relator) \\
\hline Citação de doutrina & $\begin{array}{l}\text { Cezar Roberto Bitencourt, Rogério } \\
\text { Greco e Damásio de Jesus }\end{array}$ \\
\hline Citação de julgamento anterior & 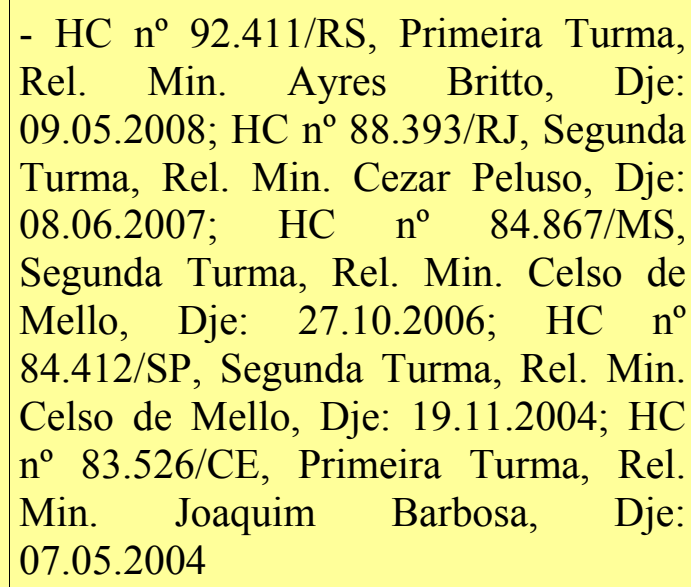 \\
\hline $\begin{array}{l}\text { Transcrição de ementa ou parte de } \\
\text { inteiro teor }\end{array}$ & 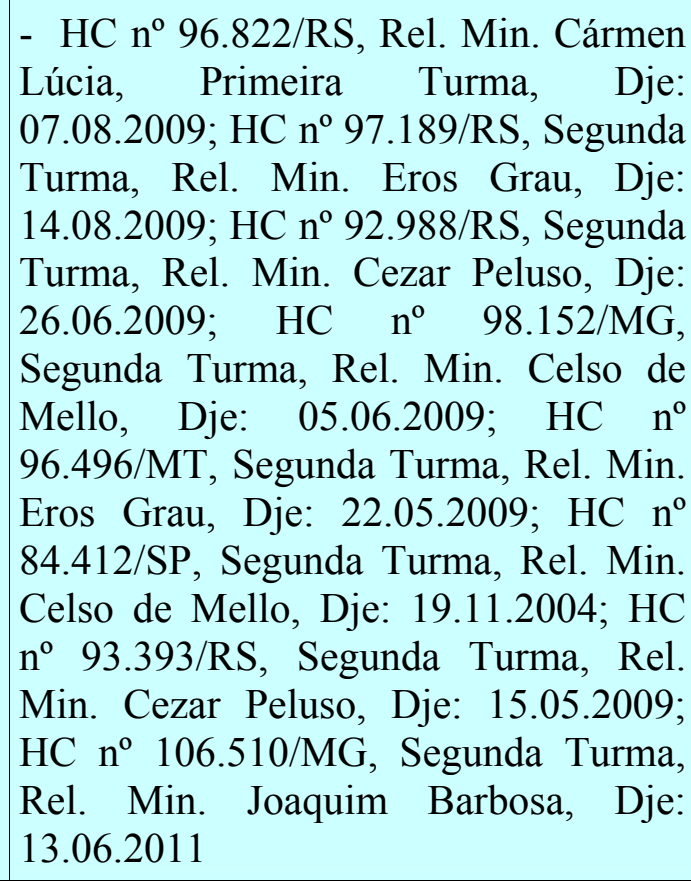 \\
\hline $\begin{array}{l}\text { Transcrição de algum parecer ou } \\
\text { manifestação? }\end{array}$ & Não \\
\hline Houve debate? & Não \\
\hline Considerações sobre a ementa & - Não fala que o paciente é reincidente \\
\hline
\end{tabular}




\begin{tabular}{|l|l|} 
Houve pedido de vista? & - Diz que há precedentes \\
Não
\end{tabular}

Tabela 14- Estrutura do inteiro teor da "Decisão G"

\title{
D. Quadro resumo dos votos
}

\begin{tabular}{|c|c|}
\hline \multicolumn{2}{|c|}{ "Decisão G"- $\mathrm{HC} \mathrm{n}^{\circ}$ 106.510/MG- 2 ${ }^{\mathrm{a}}$ Turma STF } \\
Ministro & Votação \\
Ayres Britto & Aplica-se \\
Celso de Mello & Aplica-se \\
Gilmar Mendes & Aplica-se \\
\hline Joaquim Barbosa & Ausente justificadamente \\
Ricardo Lewandowski & Ausente justificadamente \\
& Decisão unânime pela concessão da \\
ordem
\end{tabular}

Tabela 15- Quadro resumo da "Decisão G"

\subsection{3}

\author{
"Decisão H"- HC no 114.060/MG ${ }^{171}$
}

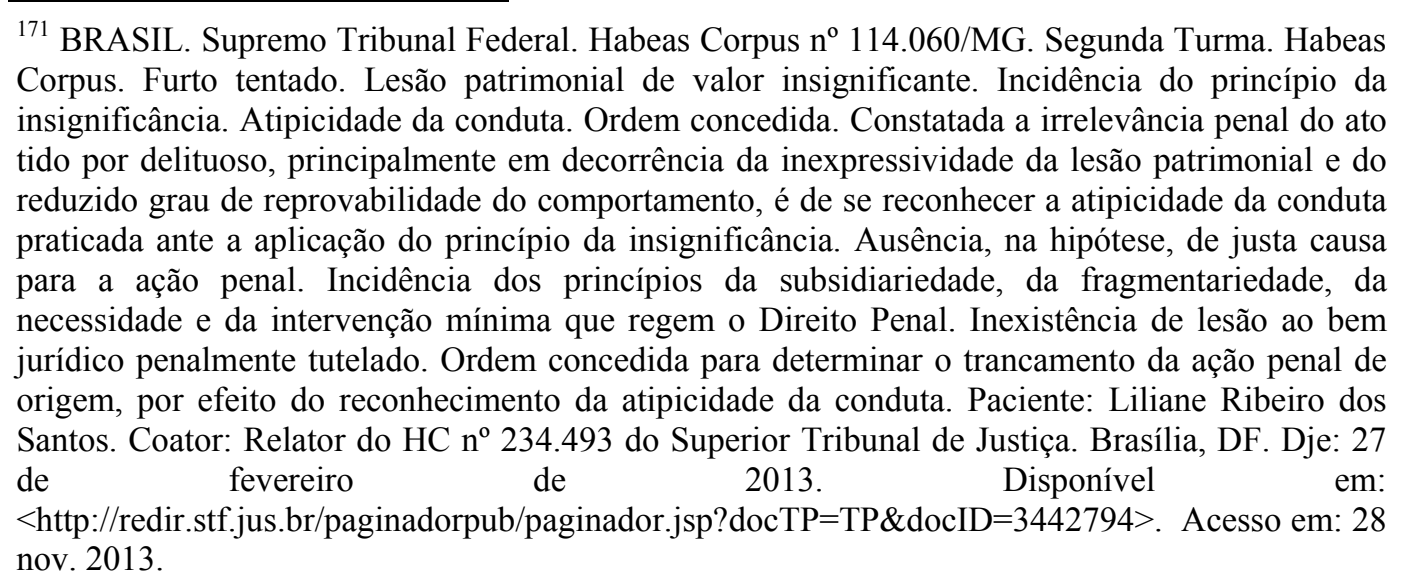




\section{A. Composição da bancada}

Presentes os Ministros Celso de Mello, Cármen Lúcia (Relatora), Gilmar Mendes e Joaquim Barbosa.

\section{B. Qualificação do caso}

Aborda a possibilidade de aplicação do princípio da insignificância a uma paciente que tentou furtar em um supermercado 2 (dois) óleos de amêndoa, 2 (dois) enxaguantes bucais, 1 (um) creme hidratante e 2 (duas) chupetas que computavam o valor de $\mathrm{R} \$ 150,00$ (cento e cinquenta reais).

\section{Exposição das decisões}

A paciente foi denunciada pela prática de furto tentado (art. 155, caput c/c art. 14, inc. II, ambos do CP). Em Primeira instância, o juízo da Quarta Vara Criminal converteu a prisão em flagrante em preventiva. A defesa pediu sua liberdade provisória, no entanto essa foi negada pelo juízo de Primeira instância. Consequentemente, a defesa impetrou um habeas corpus, que com base na maioria dos votos da Sétima Câmara Criminal do Tribunal de Justiça de Minas Gerais, foi concedida a ordem para trancamento da ação penal com base na aplicação do princípio da insignificância. Em seguimento, o Ministério Público ingressou com embargos de declaração que foram deferidos de forma unânime, no sentido da denegação da ordem, uma vez que se tratava de paciente com reincidência específica. Posteriormente, a defesa impetrou habeas corpus perante o Superior Tribunal de Justiça que denegou a ordem fundamentando que os bens subtraídos não configuraram um indiferente penal, não podendo, assim ser 
atendido um dos requisitos ${ }^{172}$ necessários à aplicação do princípio da insignificância. No caso, o reduzido grau de reprovabilidade ou a mínima ofensividade da conduta. Com base nesse julgamento, a defesa impetrou o presente habeas corpus com pedido de liminar para o trancamento da ação penal. A Ministra Relatora Cármen Lúcia indeferiu a liminar e requisitou informações e vista ao Procurador-Geral da República.

$\mathrm{O}$ julgamento do $\mathrm{HC}^{\mathrm{o}}$ 114.060/MG ocorreu no dia 25.09.2012. O inteiro teor é composto pela íntegra dos votos de Cármen Lúcia, Joaquim Barbosa, Gilmar Mendes e Ricardo Lewandowski. Houve a concessão da ordem de habeas corpus por maioria de votos, sendo vencido Lewandoski e Cármen Lúcia.

Cármen Lúcia sustenta que não cabe a concessão da ordem, pois:

a) a análise da tipicidade penal não consiste apenas na adequação do fato concreto à norma jurídica, sendo necessário também, realizar uma análise materialmente valorativa das circunstâncias do caso concreto;

b) conforme decisão da Sétima Câmara Criminal do Tribunal de Justiça de Minas Gerais, a paciente é reincidente específica no crime de furto;

c) o mesmo posicionamento foi mantido em sede de habeas corpus pelo Superior Tribunal de Justiça;

d) afirma que a decisão do Superior Tribunal de Justiça está em concordância com a Jurisprudência do Supremo Tribunal Federal, citando dois acórdãos que demonstram isso: $\mathrm{HC}^{\mathrm{o}} 107.138 / \mathrm{RS}^{173}$ e o $\mathrm{HC} \mathrm{n}^{\mathrm{o}} 102.088 / \mathrm{RS}^{174}$,

\footnotetext{
172 Os requisitos necessários para aplicação do princípio da insignificância consistem em: a) mínima ofensividade da conduta, b) nenhum periculosidade social da ação, c) reduzidíssimo grau de reprovabilidade do comportamento e d) inexpressividade da lesão jurídica provocada.

${ }^{173}$ BRASIL. Supremo Tribunal Federal. Habeas Corpus no 107.138/RS. Primeira Turma. Penal. Habeas corpus. Paciente processado pelo crime de furto simples. Absolvição. Princípio da insignificância. Inaplicabilidade. Periculosidade do agente. Furto insignificante. Furto privilegiado. Distinção. Ordem denegada. I - A aplicação do princípio da insignificância de modo a tornar a conduta atípica exige, além da pequena expressão econômica dos bens que foram objeto de subtração, um reduzido grau de reprovabilidade da conduta do agente. II - Embora o paciente não seja tecnicamente reincidente, tem personalidade voltada para a prática de crimes contra $o$ patrimônio, o que impede o atendimento de um dos requisitos exigidos por esta Corte para a configuração do princípio da insignificância, qual seja, a ausência de periculosidade do agente. III - Na espécie, a aplicação do referido instituto poderia significar um verdadeiro estímulo à prática destes pequenos furtos, já bastante comuns nos dias atuais, o que contribuiria para aumentar, ainda mais, o clima de insegurança hoje vivido pela coletividade. IV - Convém distinguir, ainda, a figura do furto insignificante daquele de pequeno valor. $\mathrm{O}$ primeiro, como é cediço, autoriza o
} 
ambos com decisão unânime;

e) reitera "que o princípio da insignificância não foi estruturado para resguardar e legitimar constantes condutas desvirtuadas, mas para impedir que desvios ínfimos, sejam sancionados pelo direito penal";

f) nos autos há certidão de antecedentes criminais que relata que a paciente sofreu uma condenação com trânsito em julgado no ano de 2007 pela prática de tentativa de furto qualificado; em 2012 há uma condenação sem trânsito em julgado pela prática de furto qualificado, além de três denúncias e um inquérito, aquelas por roubo, tentativa de furto e tentativa de furto qualificado e este por lesão corporal.

Cármen Lúcia explica o porquê de ter denegado a ordem, apontando que apesar do valor ser ínfimo ( $\mathrm{R} \$ 150,00$ - cento e cinquenta reais), a paciente é

reconhecimento da atipicidade da conduta, ante a aplicação do princípio da insignificância. Já no que tange à coisa de pequeno valor, criou o legislador a causa de diminuição referente ao furto privilegiado, prevista no art. 155, $\S 2^{\circ}$, do Código Penal. V - Ordem denegada. Paciente: Everton Cristiano Belisario. Coator: Superior Tribunal de Justiça. Relator: Ministro Ricardo Lewandowski. Brasília, DF. Dje: 30 de maio de 2011. Disponível em: $<$ http://redir.stf.jus.br/paginadorpub/paginador.jsp?docTP=TP\&docID=1195340>. Acesso em: 15 dez. 2014.

${ }^{174}$ BRASIL. Supremo Tribunal Federal. Habeas Corpus no 102.088/RS. Primeira Turma. Habeas corpus. Constitucional. Penal. Furto e tentativa de furto. Alegação de incidência do princípio da insignificância: inviabilidade. Notícia da prática de vários outros delitos pelo paciente. Habeas corpus denegado. 1. A tipicidade penal não pode ser percebida como o trivial exercício de adequação do fato concreto à norma abstrata. Além da correspondência formal, para a configuração da tipicidade, é necessária uma análise materialmente valorativa das circunstâncias do caso concreto, no sentido de se verificar a ocorrência de alguma lesão grave, contundente e penalmente relevante do bem jurídico tutelado. 2. Para a incidência do princípio da insignificância, devem ser relevados o valor do objeto do crime e os aspectos objetivos do fato tais como a mínima ofensividade da conduta do agente, a ausência de periculosidade social da ação, o reduzido grau de reprovabilidade do comportamento e a inexpressividade da lesão jurídica causada. 3. O grande número de anotações criminais na folha de antecedentes do Paciente e a notícia de que ele teria praticado novos furtos, após ter-lhe sido concedida liberdade provisória nos autos da imputação ora analisados, evidenciam comportamento reprovável. 4 . $\mathrm{O}$ criminoso contumaz, mesmo que pratique crimes de pequena monta, não pode ser tratado pelo sistema penal como se tivesse praticado condutas irrelevantes, pois crimes considerados ínfimos, quando analisados isoladamente, mas relevantes quando em conjunto, seriam transformados pelo infrator em verdadeiro meio de vida. 5. O princípio da insignificância não pode ser acolhido para resguardar e legitimar constantes condutas desvirtuadas, mas para impedir que desvios de conduta ínfimos, isolados, sejam sancionados pelo direito penal, fazendo-se justiça no caso concreto. Comportamentos contrários à lei penal, mesmo que insignificantes, quando constantes, devido a sua reprovabilidade, perdem a característica da bagatela e devem se submeter ao direito penal. 6 . Ordem denegada. Paciente: Diego Taffarel Paula da Fonseca. Coator: Superior Tribunal de Justiça. Relatora: Ministra Cármen Lúcia. Brasília, DF. Dje: 21 de maio de 2010. Disponível em: $<$ http://redir.stf.jus.br/paginadorpub/paginador.jsp?docTP=AC\&docID=611560 $>$. Acesso em: 15 de dez. 2013. 
reincidente específica. No caso, a Ministra escreve trecho do acórdão do STJ que aponta que "nem mesmo censuras penais anteriores foram suficientes para impedir seu retorno a atividades criminosas". Ademais, ressalta que a jurisprudência do Supremo "é exatamente nessas condições".

Joaquim Barbosa identificou que o caso seria de uma "espécie de criminalidade da miséria" porque se tratava de roubo de chupetas. Cármen Lúcia destacou que não, pois a paciente cometeu crime desse tipo outras vezes. Há um questionamento sobre quais seriam esses produtos e em qual categoria se inseririam. Lewandowski entendeu que se tratava de produtos de higiene.

Barbosa entendeu que se trata de um caso de miserabilidade e desesperança. A Ministra Cármen Lúcia ressalta que levou em consideração que a paciente é reincidente e que o Estado deve dar uma resposta em situações assim. Relata que já julgou casos semelhantes a esse, e que se ocorreu uma vez, ocorrerá outras vezes caso não haja uma repreensão estatal. A ministra concorda com o Ministro Gilmar Mendes, dizendo que há a necessidade de se encontrar uma "solução para esse tipo de coisa".

Destacam que a paciente já se encontra solta e o pedido é de trancamento da ação penal por atipicidade da conduta. Barbosa afirma que "o Estado que considera inofensiva, anódina a ação de descaminho ${ }^{175}$ no valor de até dez mil reais é o mesmo Estado que quer punir, de maneira severa, quem furta ou tenta furtar cento e cinquenta reais". Cármen Lúcia contesta frisando que a paciente é reincidente, havendo em sua ficha de antecedentes crime de furto e roubo, não sendo, assim, um caso isolado.

Gilmar Mendes discorda da Relatora e vota pela concessão da ordem, entendendo que:

a) o assunto "merece um esforço por parte do legislador reformador, e também de nossa parte, para contribuirmos na orientação da jurisprudência, uma

\footnotetext{
${ }^{175}$ Descaminho (art. 334 do CP) consiste em iludir, no todo ou em parte, o pagamento de direito ou imposto devido pela entrada, pela saída ou pelo consumo da mercadoria. Constitui um crime contra a ordem tributária que abarca a importação ou exportação de mercadorias permitidas.
} 
vez que, de quando em vez, nós vacilamos na nossa própria orientação"176;

b) nesse caso, deve haver um esforço para que se encontre uma uniformização dessa matéria junto aos Tribunais e Juízes, pois há casos em que o Juiz aplica o princípio da insignificância e o Tribunal reforma a decisão;

c) precisa-se "encontrar, seja o raciocínio de lege ferenda ${ }^{177}$ no plano legislativo, mas seja também no plano judicial, um tratamento adequado"; ressalta que a grande quantidade de processos que envolvem essa matéria e que toda semana há aproximadamente 4 (quatro) processos no STF na pauta de julgamento;

d) "seria interessante se pensássemos conjuntamente com a Primeira Turma- e, talvez, até mesmo em Plenário- numa solução para essa temática”.

Logo depois Lewandowski acompanha o voto de Cármen Lúcia salientando que:

a) quando se trata da possibilidade de aplicação ou não do princípio da insignificância, tem feito distinções, até mesmo quando se trata de crimes tributários;

b) conquanto o valor envolvido no crime de furto seja baixo, a paciente é criminosa habitual, não podemos tratar com indiferença essas condutas, porque negá-las poderia constituir um estímulo às mesmas;

c) outro fator de relevante importância é que se o Estado não der uma resposta, mesmo quando se trata de furto de produtos de pequeno valor, a sociedade se inclinará a fazer justiça com as próprias mãos;

d) concorda com o Ministro Gilmar Mendes que há a necessidade de uma reflexão sobre esse assunto, nem que seja através dos meios acadêmicos, pois se trata de um assunto que envolve competência do Congresso Nacional e, possivelmente, o Supremo Tribunal Federal poderia contribuir para o debate;

Em seguida, há apontamentos tanto de Barbosa quanto de Cármen Lúcia. O Ministro Barbosa frisa que:

a) devemos "buscar critérios para tratar desse tipo de criminalidade", pois

\footnotetext{
${ }^{176}$ Observe que de modo claro, o Ministro Gilmar Mendes admite que o STF tem sido incoerente nas suas decisões sobre julgamentos que versam sobre essa matéria.

${ }^{177}$ Lege ferenda significa a lei que deve ser criada. Em outras palavras pode-se entender como uma visão futura do direito.
} 
há casos em que o baixo valor para a maioria da sociedade pode não ser baixo para a vítima;

b) considera essa questão deve ser repensada, destacando que não considera que "esse tipo de criminalidade seja a criminalidade que mais ofenda a sociedade. A criminalidade que mais ofende a sociedade brasileira é a criminalidade do colarinho branco, essa criminalidade que ofende o patrimônio público".

Já a Ministra Cármen Lúcia sinaliza que:

a) o art. $155, \S 2^{\circ}$ do $\mathrm{CP}^{178}$ seria uma alternativa considerável quando se trata de furtos de pequeno valor;

b) há muitas diferenças sociais e econômicas no Brasil, o seu retrato é muito diferente do que ilustra a Avenida Paulista ou a Nossa Senhora de Copacabana.

\section{Estrutura do inteiro teor}

\begin{tabular}{|c|c|}
\hline Páginas do inteiro teor & 25 páginas \\
\hline Transcrição integral do voto & $\begin{array}{l}\text { Ministros Cármen Lúcia (Relatora), } \\
\text { Joaquim Barbosa, Gilmar Mendes e } \\
\text { Ricardo Lewandowski }\end{array}$ \\
\hline Citação de doutrina & Não \\
\hline Citação de julgamento anterior & Não \\
\hline $\begin{array}{l}\text { Transcrição de ementa ou parte de } \\
\text { inteiro teor }\end{array}$ & $\begin{array}{l}\text { - Min. Cármen Lúcia: HC } \mathrm{n}^{\mathrm{o}} \\
\text { 107.138/RS, Primeira Turma, Rel. } \\
\text { Min. Ricardo Lewandowski, Dje: } \\
\text { 30.05.2011; HC n }{ }^{\circ} \text { 102.088/RS, } \\
\text { Primeira Turma, Rel. Min. Cármen } \\
\text { Lúcia, Dje: } 21.05 .2010\end{array}$ \\
\hline $\begin{array}{l}\text { Transcrição de algum parecer ou } \\
\text { manifestação? }\end{array}$ & $\begin{array}{l}\text { - Min. Cárı } \\
\text { parte do par }\end{array}$ \\
\hline
\end{tabular}

\footnotetext{
${ }^{178}$ Art. 155 do CP: $\S 2^{\circ}$ - Se o criminoso é primário, e é de pequeno valor a coisa furtada, o juiz pode substituir a pena de reclusão pela de detenção, diminuí-la de um a dois terços, ou aplicar somente a pena de multa.
} 


\begin{tabular}{|l|l|} 
Houve debate? & $\mid$ da República \\
Considerações sobre a ementa & $\mid$ Sim ${ }^{179}$ \\
Houve pedido de vista? & Não fala que o paciente é reincidente \\
\hline
\end{tabular}

Tabela 16- Estrutura do inteiro teor da "Decisão H"

\section{E. Quadro resumo dos votos}

\begin{tabular}{|c|c|}
\hline \multicolumn{2}{|c|}{ “Decisão H”- HC nº 114.060/MG- 2ª Turma STF } \\
\hline Ministro & Votação \\
\hline Cármen Lúcia & Não se aplica \\
\hline Celso de Mello & Aplica-se \\
\hline Gilmar Mendes & Aplica-se \\
\hline Joaquim Barbosa & Aplica-se \\
\hline \multirow[t]{2}{*}{ Ricardo Lewandowski } & Não se aplica \\
\hline & A Turma, por maioria, concedeu a ordem \\
\hline
\end{tabular}

\section{2 .4}

\section{"Decisão I"- HC nº 113.782/RS ${ }^{180}$}

${ }^{179}$ Em certa medida, visualiza-se um debate entre os ministros. No entanto, os questionamentos levantados pelo Ministro Gilmar Mendes com relação a necessidade de se solucionar o impasse existente com relação à aplicação do princípio da insignificância foram ignorados.

${ }^{180}$ BRASIL. Supremo Tribunal Federal. Habeas Corpus no 113.712/RS. Segunda Turma. Penal. Habeas corpus. Paciente condenado pelo crime de furto tentado. Princípio da insignificância. Inaplicabilidade. Reprovabilidade e ofensividade da conduta do agente. Reincidência. Ação Penal. Nulidade. Alegação. Improcedência. Prejuízo. Demonstração. Ausência. Ordem Denegada. I - A aplicação do princípio da insignificância, de modo a tornar a ação atípica, exige a satisfação, de forma concomitante, de certos requisitos, quais sejam, conduta minimamente ofensiva, ausência de periculosidade social da ação, reduzido grau de reprovabilidade do comportamento e lesão jurídica inexpressiva. II - Não se pode considerar reduzido o grau de reprovabilidade da conduta de agente que, cumprindo pena em regime semiaberto, vem a praticar novo delito. III - Ademais, infere-se 


\section{A. Composição da bancada}

Presentes à sessão os Ministros Cármen Lúcia, Gilmar Mendes, Ricardo Lewandowski (Relator), Teori Zavascki. O Ministro Gilmar Mendes não participou do julgamento, enquanto o Ministro Celso de Mello teve sua ausência justificada.

\section{B. Qualificação do caso}

O caso trata da possibilidade de aplicação ou não do princípio da insignificância a um paciente que cometeu furto tentado de uma caixa de SEDEX dos Correios, na qual havia componentes eletrônicos de informática. Os bens foram considerados de baixo valor aquisitivo apesar de não ter ocorrido qualquer tipo de avaliação monetária sobre os mesmos.

\section{Exposição das decisões}

Em primeira instância o paciente foi condenado pela prática do crime de

\footnotetext{
dos autos que o paciente dá mostras de fazer das práticas criminosas o seu modus vivendi, uma vez que ostenta várias condenações por crimes contra o patrimônio, uma delas com trânsito em julgado, o que denota a reprovabilidade e ofensividade da conduta. IV - Na espécie, a aplicação do referido instituto poderia significar um verdadeiro estímulo à prática desses pequenos furtos, já bastante comuns nos dias atuais, o que contribuiria para aumentar, ainda mais, o clima de insegurança hoje vivido pela coletividade. $\mathrm{V}$ - A pena, de resto, estabelecida em 1 ano e 2 meses de reclusão, que não foi substituída por sanção restritiva de direitos ante a vedação legal prevista no art. 44, II, do Código Penal (reincidência), não desbordou os lindes da proporcionalidade e da razoabilidade, mostrando-se adequada ao caso concreto e necessária à repressão e prevenção de novos delitos. VI - É entendimento desta Corte que, para o reconhecimento de eventual nulidade, ainda que absoluta, faz-se necessária a demonstração do prejuízo, o que não ocorreu no caso sob exame. Precedentes. VII - Ordem denegada. Paciente: Daniel Mendes Leguisamo. Coator: Superior Tribunal de Justiça. Relator: Ministro Ricardo Lewandowski. Brasília, DF. Dje: 17 de junho de 2013.2 Disponível em: $<$ http://redir.stf.jus.br/paginadorpub/paginador.jsp?docTP=TP\&docID=4003515>. Acesso em: 10 jan. 2014.
} 
furto (art. 155, caput, CP). A defesa recorreu, apelando para o Tribunal de Justiça do Rio Grande do Sul, o qual negou o recurso, mas desclassificou o crime para a forma tentada (art. 14, inciso II, CP). Após, a defesa recorreu perante o STJ. Sem sucesso, impetrou o presente habeas corpus.

$\mathrm{O}$ julgamento do $\mathrm{HC} \mathrm{n}^{\mathrm{o}}$ 113.782/RS ocorreu no dia 04.06.2013 tendo como Relator o Ministro Ricardo Lewandowski. Seu inteiro teor é composto tão somente do relatório e da transcrição do voto integral do relator. A decisão foi unânime no sentido da denegação da ordem de habeas corpus.

Lewandowski afirma que:

a) não assiste razão à impetrante;

b) para que haja a configuração do crime de bagatela é necessário que alguns requisitos estejam preenchidos, tais como: a) conduta minimamente ofensiva; b) reduzido grau de reprovabilidade do comportamento e c) lesão jurídica inexpressiva;

c) furtar uma encomenda em poder da empresa de Correios é uma conduta com intensa reprovabilidade;

d) o paciente possui extensa ficha de antecedentes criminais e é reincidente, o que demonstra que o mesmo faz do crime um modo de vida;

e) na aplicação do princípio da insignificância não se leva apenas em consideração a baixa expressão econômica da lesão;

f) a Segunda Turma apresentava divergência com relação a se considerar às questões relativas à pessoa do agente quando se verifica a possibilidade ou não de aplicação do princípio da insignificância; o ministro afirma que a Segunda Turma, por maioria, firmou entendimento que a relevância penal deve ser aferida com base na contumácia do agente, conforme o RHC n ${ }^{\circ} 115.226 / \mathrm{MG}^{181}$;

g) transcreve parte do inteiro teor do HC 108.872/RS ${ }^{182}$ ("Decisão G"), fundamentando que na aferição da aplicação do princípio da bagatela, deve-se recorrer ao princípio da proporcionalidade;

h) entende que no caso em tela, o agente apresenta periculosidade e sua

\footnotetext{
${ }^{181}$ BRASIL, STF, RHC no 115.226/MG, Rel. Min. Cármen Lúcia, Dje: 21.11.2013.

182 BRASIL, STF, HC n ${ }^{\circ}$ 108.872/RS, Rel. Min. Gilmar Mendes, Dje: 23.09.2011.
} 
conduta é reprovável; tais fatos permitem a continuidade da ação penal;

i) no caso em análise, o bem objeto de furto não foi avaliado monetariamente; no entanto, isso não afeta o paciente, uma vez que o que impede a aplicação do princípio da insignificância é a reincidência;

j) denega a ordem de habeas corpus.

\section{Estrutura do inteiro teor}

\begin{tabular}{|c|c|}
\hline Páginas do inteiro teor & 11 páginas \\
\hline Transcrição integral do voto & $\begin{array}{lll}\text { Ministro } & \text { Ricardo } & \text { Lewandowski } \\
\text { (Relator) } & & \end{array}$ \\
\hline Citação de doutrina & Não \\
\hline Citação de julgamento anterior & Não \\
\hline $\begin{array}{l}\text { Transcrição de ementa ou parte de } \\
\text { inteiro teor }\end{array}$ & $\begin{array}{l}\text { - } \mathrm{RHC} \mathrm{n}^{\mathrm{o}} \text { 115.226/MG, Segunda } \\
\text { Turma, Rel. Min. Cármen Lúcia, Dje: } \\
\text { 14.05.2013; HC } \mathrm{n}^{\mathrm{o}} \text { 108.872/RS, } \\
\text { Segunda Turma, Rel. Min. Gilmar } \\
\text { Mendes, Dje: 23.09.2011; HC }{ }^{\circ} \\
\text { 85.155/SP, Segunda Turma, Rel. Min. } \\
\text { Ellen Gracie, DJ: 15.04.2005; HC n } \\
\text { 82.899/SP, Segunda Turma, Rel. Min. } \\
\text { Cezar Peluso, Dje: 26.06.2009 }\end{array}$ \\
\hline $\begin{array}{l}\text { Transcrição de algum parecer ou } \\
\text { manifestação? }\end{array}$ & $\begin{array}{l}\text { Sim, manifestação do Ministério } \\
\text { Público Federal }\end{array}$ \\
\hline Houve algum debate? & Não \\
\hline Considerações sobre a ementa & Fala que o paciente é reincidente \\
\hline Houve pedido de vista? & Não \\
\hline
\end{tabular}

Tabela 18- Estrutura do inteiro teor da "Decisão l"

\section{E. Quadro resumo dos votos}

“Decisão I”- HC no 113.782/RS- 2 ${ }^{\mathrm{a}}$ Turma STF 


\begin{tabular}{|c|c|}
\hline Ministro & Votação \\
\hline Cármen Lúcia & Não se aplica \\
\hline Celso de Mello & Ausente justificadamente \\
\hline Gilmar Mendes & Não participou justificadamente \\
\hline Ricardo Lewandowski & Não se aplica \\
Teori Zavascki & Não se aplica \\
& Decisão unânime pela denegação da \\
& ordem \\
\hline
\end{tabular}

Tabela 19- Quadro resumo dos votos da "Decisão I" 


\section{4}

\section{Análise das decisões}

\section{1}

\section{Furto simples consumado}

\subsection{1}

\section{"Decisão A"- HC n 93.393/RS}

O fato de haver apenas a transcrição do voto de Peluso, além de todos os demais votos terem sido no mesmo sentido do voto do Relator, demonstra que Eros Grau, Joaquim Barbosa e Celso de Mello acompanharam o relator. Visualiza-se, assim, um cenário em que a deliberação não foi prestigiada.

Nota-se que a ementa da decisão não reproduz que o paciente é reincidente, identificando-se uma falta de harmonia entre o conteúdo da ementa e os argumentos aduzidos no voto do relator. Nesse caso, a busca foi possível por meio das "palavras-chaves" utilizadas no site do STF, pois a indexação do voto faz referência à "reincidência específica". Além disso, a ementa indica que há precedentes no sentido da votação proferida. Entende-se que a utilização da palavra "precedentes" gera uma acepção parcial em sua construção.

\subsection{2}

“Decisão B"- HC n 97.007/SP

Apresenta-se apenas com o voto integral do Ministro Relator Joaquim Barbosa que, de modo breve, entende que não assiste razão ao paciente. Barbosa 
faz referência ao HC $n^{\circ} 100.240 / \mathrm{RJ}^{183-184}$ julgado pela Segunda Turma, no qual a defesa requer a aplicação do princípio da bagatela a um paciente que praticou a conduta de violação ao direito autoral, pois teria exposto à venda inúmeros adesivos que continham imagens de super-heróis e personagens infantis.

Entende-se que há uma incoerência nos votos de Barbosa, pois ao compararmos o presente caso com a "Decisão A", sustenta posições diferentes, visto que nesse julgamento seu voto foi pela concessão da ordem de habeas corpus. Já com relação ao $\mathrm{HC} \mathrm{n}^{0}$ 97.007/SP, Barbosa votou pela sua denegação. Estranha é a mudança de posicionamento do ministro em casos parecidos. Avaliase que é necessária a exposição de fundamentos que levaram o ministro a abandonar a postura da "Decisão A". Pode-se cogitar, inicialmente, em uma sinalização de alteração de posicionamento por Barbosa ${ }^{185}$.

Constata-se uma incoerência com relação ao voto de Celso de Mello, pois na "Decisão A" votou pela concessão da ordem, enquanto na "Decisão B" denegou a ordem.

A presente decisão apresenta apenas a transcrição do voto do Ministro Barbosa. Os Ministros Ayres Britto, Ellen Gracie, Gilmar Mendes e Celso de Mello votaram seguindo o relator. Depreende-se, assim, que não houve debate entre os julgadores.

Com relação à ementa da decisão, visualiza-se que esta reproduz de forma clara e objetiva o caso tratado, apontando que o réu é reincidente e possui habitualidade delitiva comprovada. A única ponderação que se faz é com relação ao uso da palavra "precedentes". Entende-se que seu uso gera uma significação incompleta, uma vez que não se pode defender a existência de precedentes do STF com relação ao tema em debate, a não ser da Primeira Turma.

\footnotetext{
${ }^{183}$ BRASIL, STF, HC n ${ }^{\text {o }}$ 100.240/RJ, Rel. Min. Joaquim Barbosa, Dje: 02.03.2011.

${ }^{184}$ A decisão foi unânime pela da denegação da ordem.

185 Apreende-se que o Ministro Barbosa pode ter mudado seu posicionamento com relação a essa questão, tendo em vista o voto proferido pelo ministro na "Decisão D". Frisa-se que, em momento algum, o ministro apontou uma superação em seu entendimento. Defende-se que é indispensável essa indicação na transcrição do inteiro teor, caso contrário, não há um cenário de respeito aos seus próprios autoprecedentes.
} 


\subsection{3 \\ "Decisão C"- HC no 107.184/RS}

Composta pelos votos integrais dos Ministros Gilmar Mendes (Relator) e Ayres Britto. Ambos votam no sentido da aplicação do princípio da insignificância, contrariando os votos proferidos na "Decisão B".

Mendes afirma que "esta Suprema Corte consolidou o entendimento no sentido de que os aspectos meramente subjetivos- que se pode citar reincidência e maus antecedentes-, não descaracterizariam a incidência do princípio da bagatela, sob pena, inclusive, de se criar um indesejável direito penal do autor". Para afirmar isso, o ministro transcreve 3 (três) acórdãos ( $\mathrm{HC} \mathrm{n}^{\circ}$ 96.822/RS ${ }^{186}$; $\mathrm{HC} \mathrm{n}^{\circ}$ 92.988/RS ${ }^{187}, \mathrm{HC} \mathrm{n}^{\mathrm{o}} 92.740 / \mathrm{PR}^{188}$ ). Apenas alguns ministros do STF consideram

\footnotetext{
${ }^{186}$ BRASIL. Supremo Tribunal Federal. Habeas Corpus n ${ }^{\circ}$ 96.822/RS. Primeira Turma. Habeas corpus. Penal. Processual penal. Tentativa de furto. Inexistência de lesão a bem juridicamente protegido. Princípio da insignificância: incidência. Análise reservada aos aspectos objetivos do fato. Precedentes. Ordem concedida. 1. A tentativa de furto praticada pela Paciente não resultou em dano ou perigo concreto relevante, de modo a lesionar ou colocar em perigo o bem jurídico reclamado pelo princípio da ofensividade. A conduta tem contornos que demonstram pouca importância de relevância na seara penal, pois, apesar de haver lesão a bem juridicamente tutelado pela norma, incide, na espécie, o princípio da insignificância, que reduz o âmbito de proibição aparente da tipicidade legal e, por consequência, torna atípico o fato denunciado. 2. A jurisprudência deste Supremo Tribunal admite, em casos específicos, a incidência do princípio da insignificância, em face de aspectos objetivos do fato. Tais aspectos apresentam-se no caso, a autorizar a concessão da ordem pleiteada. 3. Ordem concedida. Paciente: Rita Maria Lost de Freitas. Coator: Relator do Recurso Especial No 987733 do Superior Tribunal De Justiça. Relatora: Ministra Cármen Lúcia. Brasília, DF. Dje: 07 de agosto de 2009. Disponível em: $<$ http://redir.stf.jus.br/paginadorpub/paginador.jsp?docTP=AC\&docID=599264>. Acesso em: 22 nov. 2013.

${ }^{187}$ BRASIL. Supremo Tribunal Federal. Habeas Corpus n ${ }^{\circ}$ 92.822/RS. Segunda Turma. Ação Penal. Delito de furto. Subtração de aparelho de som de veículo. Tentativa. Coisa estimada em cento e trinta reais. Res furtiva de valor insignificante. Inexistência de fuga, reação, arrombamento ou prejuízo material. Periculosidade não considerável do agente. Circunstâncias relevantes. Crime de bagatela. Caracterização. Aplicação do princípio da insignificância. Atipicidade reconhecida. Absolvição decretada. HC concedido para esse fim. Precedentes. Verificada a objetiva insignificância jurídica do ato tido por delituoso, à luz das suas circunstâncias, deve o réu, em recurso ou habeas corpus, ser absolvido por atipicidade do comportamento, quando tenha sido condenado. Paciente: Ezequiel Castro da Rosa. Coator: Superior Tribunal de Justiça. Relator: Ministro Cezar Peluso. Brasília, DF. Dje: 26 de junho de 2009. Disponível em: $<\mathrm{http}: / /$ redir.stf.jus.br/paginadorpub/paginador.jsp?docTP=AC\&docID=597896>. Acesso em: 25 nov. 2013.

${ }^{188}$ BRASIL. Supremo Tribunal Federal. Habeas Corpus no $92.740 /$ PR. Primeira Turma. Habeas corpus. Constitucional. Penal e processual penal. Trancamento da ação penal. Paciente condenado pela infração do art. 334, caput, do código penal (descaminho). Alegação de incidência do
} 
que as circunstâncias subjetivas, incluída aqui a reincidência, não impedem a aplicação do referido princípio. Não há uma posição consolidada no STF com relação a essa questão ${ }^{189}$.

Quando o Ministro Mendes afirma que a "Suprema Corte consolidou o entendimento (...)", entende-se que o mesmo realiza uma declaração inadequada tendo em vista que:

a) o julgamento do "Decisão C" data de 18/10/2013, enquanto os acórdãos em referência são do ano de 2009 e 2008, ou seja, são decisões que possuem um considerável lapso temporal em comparação ao julgamento;

b) apesar da tese do ministro ser no sentido da desconsideração dos aspectos subjetivos ${ }^{190}$, não vemos coerência ao se utilizar o $\mathrm{HC} \mathrm{n}^{\circ}$ 92.740/PR que é referente ao crime de descaminho (art. 334, caput, $\mathrm{CP}^{191}$ ).

Sustenta-se que outro tipo penal não fornece um parâmetro adequado de argumentação. A figura típica do furto é diferente do descaminho, sendo este um crime praticado por particular contra a administração em geral, enquanto aquele, um crime contra o patrimônio. Além disso, o crime de descaminho possui um tratamento especial com relação à aplicação do princípio da insignificância ${ }^{192}$.

princípio da insignificância. Existência de precedente deste supremo tribunal favorável à tese da impetração. Habeas corpus deferido para determinar o trancamento da ação penal. Paciente: Adriano Severino José da Silva. Coator: Relator do Recurso Especial No 767634 do Superior Tribunal De Justiça. Relatora: Ministra Cármen Lúcia. Dje: 28 de março de 2008. Disponível em: $<$ http://redir.stf.jus.br/paginadorpub/paginador.jsp?docTP=AC\&docID=516845>. Acesso em: 25 nov. 2013

189 Novamente o que poderíamos defender seria um posicionamento consolidado da Primeira Turma do STF.

${ }^{190}$ Entende-se que o Ministro Gilmar Mendes propôs uma análise incompleta ao citar como fundamento de sua tese o $\mathrm{HC}^{\circ}$ 96.822/RS, $\mathrm{HC} \mathrm{n}^{\circ}$ 92.988/RS e $\mathrm{HC}^{\circ}$ 92.740/PR, uma vez que: a) o $\mathrm{HC}^{\circ}$ 96.822/RS trata de um caso de furto tentado em que houve concurso de pessoas, sendo que apenas uma das denunciadas possuía condenação definitiva por delitos da mesma espécie; No $\mathrm{HC}^{\circ}$ 92.988/RS aborda-se um caso de delito de furto tentado, sendo que o inteiro teor da decisão em momento algum fala que o paciente seria reincidente ou possuía maus antecedentes; c) $\mathrm{HC}^{\circ}$ 92.740/PR além do fato de versar sobre um outro crime, o de descaminho (art. 334, CP), o inteiro teor apenas relata que há a existência de registros criminais contra o réu pelo mesmo delito. Mesmo que a tese do Ministro Gilmar seja a de que as condições de caráter subjetiva devam ser desconsideradas na aplicação do princípio da bagatela, entende-se que os casos não são adequados para servirem como parâmetro de comparação.

191 Art. 334, CP: Importar ou exportar mercadoria proibida ou iludir, no todo ou em parte, o pagamento de direito ou imposto devido pela entrada, pela saída ou pelo consumo de mercadoria: Pena - reclusão, de um a quatro anos.

${ }^{192}$ Ver item 4.3.3. (análise da "Decisão H”). 
Ayres Britto, Gilmar Mendes e Celso de Mello proferiram votos contrários ao da "Decisão B", sem explicar o porquê dessa mudança, o que demonstra a incoerência presente nesse julgamento. Por outro lado, observando-se o "Quadro 03" verifica-se que os Ministros Mendes e Mello votam de forma divergente em casos semelhantes. O Ministro Mendes concede a ordem nas decisões "C" e " $D$ ", enquanto nas decisões "B" e "E" denega a ordem. Já o Ministro Mello concede a ordem nas decisões "A", "C" e "D" e a denega na decisão "B". Nesse panorama, não há como se considerar uma possível superação de entendimento, tendo em vista o desrespeito aos autoprecedentes.

No que tange à fundamentação das decisões, observa-se que dos 4 (quatro) ministros que participaram do julgamento, 3 (três) mudaram de posição ao compararmos com a "Decisão B". Ayres Britto concede a ordem na "Decisão C" sem argumentar o porquê dessa mudança ${ }^{193}$. Situação semelhante se aplica ao Ministro Gilmar Mendes. Dentro desse quadro, não há como se confrontar as fundamentações das decisões.

Há um erro no inteiro teor do acórdão, pois ao final consta que Joaquim Barbosa estaria ausente justificadamente. Após isso, coloca-se que Barbosa estaria presente juntamente com os Ministros Ayres Britto, Celso de Mello, Gilmar Mendes e Ricardo Lewandowski. Para maiores esclarecimentos, a partir de uma busca que levava em consideração outras decisões proferidas pela Segunda Turma no dia 18 de outubro de 2011 no site do Supremo Tribunal Federal, constatou-se que em todos os outros acórdãos da mesma data há o mesmo erro. Por esse motivo, optou-se por considerar que Joaquim Barbosa estava ausente nesse dia, desconsiderando-se, assim, seu voto.

Não houve diálogo entre os ministros. Além disso, a ementa do acórdão não traduz de forma completa o caso, uma vez que não expõe a reincidência do paciente. Frisa-se que a busca no sítio eletrônico do STF foi possível porque a

193 Observa-se que a na "Decisão B" há tão somente o resultado do voto do Ministro Ayres Britto, enquanto na "Decisão C" há a transcrição do voto. Desse modo, não há como compararmos as fundamentações. A mesma situação se aplica ao Ministro Gilmar Mendes em que temos apenas o resultado do voto na "Decisão B", ao passo que na "Decisão C" há a transcrição de seu voto. Já com relação ao Ministro Celso de Mello, tanto na "Decisão B" quanto na "Decisão C" só há o resultado. 
indexação do voto fez menção à "reincidência" do paciente. Por fim, o uso da palavra "precedentes" indica uma acepção parcial em sua estrutura, pelos motivos já expostos.

\subsection{4}

\section{"Decisão D"- HC n 109.870/RS}

O Relator Barbosa denega a ordem de habeas corpus e vota conforme posicionamento adotado na "Decisão B", sugerindo uma possível mudança em seu entendimento, haja vista a aplicação do princípio da insignificância na "Decisão A".

Em seu exame, Barbosa diz que "não é razoável que o fracionamento da prática usual de condutas reprováveis possa beneficiar o infrator habitual, sobretudo o reincidente, possuidor de condenações transitadas em julgado nos seus antecedentes". Após, o Ministro Joaquim Barbosa faz referência ao HC n 97.772/RS (Primeira Turma, Rel. Min. Cármen Lúcia, Dje: 20.11.2009), afirmando que se trata de um precedente do STF. O citado habeas corpus faz referência a um caso de tentativa de furto com invasão de domicílio perpetrada por um paciente reincidente. A partir desse acórdão, defende que um indivíduo reincidente não pode ser beneficiado pelo princípio da insignificância, ao se considerar a reprovabilidade do seu histórico comportamental.

Considera-se que o relator adotou um viés equivocado, pois: a) não há como se afirmar que o Supremo Tribunal Federal possui precedente no sentido de que a reincidência afastaria a aplicação do princípio da bagatela; b) pode-se sustentar que há precedentes somente da Primeira Turma; c) o Ministro Barbosa se valeu de um julgado da Primeira Turma, fato este que reforça a ideia de que haveria tão somente uma posição consolidada na Primeira Turma e d) entende-se que uma tese completa por parte do ministro, deve estar vinculada a um caso de furto consumado simples em que o paciente seja reincidente.

Em seguida, há o voto de Lewandowski que, brevemente, profere seu voto 
no sentido da denegação da ordem. Sua postura demonstra uma incongruência com seu voto tomado na "Decisão C" em que o Ministro concedeu a ordem. Não há como se comparar o conteúdo das fundamentações, uma vez que a "Decisão C" não possui a íntegra do voto do Ministro Ricardo Lewandowski.

Gilmar Mendes menciona que há precedentes da Segunda Turma no sentido de que a discussão residiria na tipicidade em sua forma objetiva e, consequentemente, em um caso em que a ordem deve ser concedida. Ratificando sua tese, transcreve trechos de 3 (três) acórdãos: $\mathrm{HC} \mathrm{n}^{\circ} 109.783 / \mathrm{MG}^{194}, \mathrm{HC} \mathrm{n}^{\mathrm{o}}$ 93.393/RS (“Decisão A”) e HC no 106.510/MG (“Decisão F”).

$\mathrm{O} \mathrm{HC} \mathrm{n}^{\circ}$ 109.783/MG versa sobre um caso de tentativa de furto em concurso de pessoas de um pacote de linguiças no valor de $\mathrm{R} \$ 51,00$ (cinquenta e um reais), em que o paciente possui maus antecedentes. O ministro sustenta uma análise incompleta, pois: a) o $\mathrm{HC} \mathrm{n}^{\circ} 109.783 / \mathrm{MG}$ refere-se a outro caso que não se enquadra nos parâmetros da "Decisão D", porque trata de furto tentado em concurso com pessoas, sendo que o paciente possui maus antecedentes; b) a "Decisão F" aborda um caso de furto tentado simples e não de furto consumado simples; c) há a afirmação equivocada do ministro de que há precedentes da Segunda Turma que confirmam sua posição.

Observa-se uma inconsistência na postura de Gilmar Mendes, uma vez que nas decisões " $B$ " e "E" a ordem foi denegada, enquanto nas decisões " $C$ " e " $D$ " concedeu a ordem. Não há dados suficientes para se comparar as fundamentações das decisões, uma vez que apenas nas decisões "C $C$ " e " $D$ " há a transcrição de seu voto. O que chama a atenção é o fato de o Ministro Mendes nas decisões "C" e "D", em momento algum, não ter apontado o motivo que o levou a mudar sua posição.

Extrai-se que houve debate entre os ministros. Já a ementa da decisão

\footnotetext{
${ }^{194}$ BRASIL. Supremo Tribunal Federal. Habeas Corpus no 109.783/MG. Segunda Turma. Habeas Corpus. 2.Tentativa de furto. Bem de pequeno valor (R\$ 51,00). Mínimo grau de lesividade da conduta. 3. Aplicação do princípio da insignificância. Possibilidade. Precedentes. 4. Antecedentes criminais. Irrelevância de considerações de ordem subjetiva. 5. Ordem concedida. Paciente: Mancone Marques Pacheco. Coator: Superior Tribunal de Justiça. Relator: Ministro Gilmar Mendes. Brasília, DF. Dje: 27 de outubro de 2011. Disponível em: $<$ http://stf.jusbrasil.com.br/jurisprudencia/20760124/habeas-corpus-hc-109783-mg-stf >. Acesso em: 13 dez. 2013.
} 
demonstra que o paciente possuía a agravante da reincidência. Por outro lado, a mesma é constituída da palavra "precedentes", fato este que constitui uma inexatidão na abordagem do assunto, conforme já defendido.

\subsection{5}

\section{"Decisão E"- HC n 118.089/MG}

A Ministra Cármen Lúcia afirma que a decisão em sede de agravo regimental do STJ está "em harmonia com a jurisprudência do Supremo Tribunal Federal" transcrevendo os seguintes julgados: $\mathrm{HC} \mathrm{n}^{\circ} 108.403 / \mathrm{RS} 195, \mathrm{HC} \mathrm{n}^{\mathrm{o}}$ 111.608/RS196 e $\mathrm{HC} \mathrm{n}^{\mathrm{o}} 107.138 / \mathrm{RS}^{197}$.

$\mathrm{O} \mathrm{HC} \mathrm{n}^{\circ} 108.403 / \mathrm{RS}$ foi julgado pela Primeira Turma do STF e refere-se à ocorrência de furto tentado (art. 155, caput, c/c art. 14, II, do CP) de 1 (uma) bolsa com documentos, cartões de crédito, 1 (um) celular e R\$ 50,00 (cinquenta reais). Trata-se de paciente que possuí 3 (três) condenações e responde por 2 (dois) processos por crimes da mesma espécie. Por maioria dos votos, a turma denegou a ordem de habeas corpus.

Já o HC no 111.608/RS, julgado pela Segunda Turma, versa sobre crime de receptação (art. 180, $\mathrm{CP}^{198}$ ), pois o paciente teria adquirido um telefone celular avaliado em $\mathrm{R} \$ 50,00$ (cinquenta reais). No caso, embora o crime envolva um bem de pequeno valor, os ministros consideraram que o tipo penal da receptação traz outros crimes, até mais graves. Nesse contexto, deve-se avaliar também a reprovabilidade da conduta, tendo em vista que houve a aquisição de um produto advindo de um crime. Além desse aspecto, levou-se em consideração a reiteração criminosa do paciente, já que em sua Ficha de Antecedentes Criminais (FAC) constavam 5 (cinco) ações penais e curso - duas por furto, uma por homicídio

\footnotetext{
${ }^{195}$ BRASIL, STF, HC n ${ }^{\text {o }}$ 108.403/RS, Rel. Min. Luiz Fux, Dje: 18.03.2013.

${ }^{196}$ BRASIL, STF, HC n ${ }^{\circ}$ 111.608/RS, Rel. Min. Ricardo Lewandowski, Dje: 20.09.2012.

${ }^{197}$ BRASIL, STF, HC n ${ }^{\circ}$ 107.138/RS, Rel. Min. Ricardo Lewandowski, Dje: 30.05.2011.

198 Art. 180- Adquirir, receber, transportar, conduzir ou ocultar, em proveito próprio ou alheio, coisa que sabe ser produto de crime, ou influi para que terceiro, de boa-fé, a adquira, receba ou oculte: Pena- reclusão, de 1 (um) a 4 (quatro) anos, e multa.
} 
qualificado, uma por delito de violência doméstica e outra por cometimento de roubo/extorsão-, fatos suficientes para a não aplicação do princípio da insignificância. Por votação majoritária, indeferiu-se o pedido de habeas corpus.

$\mathrm{OHC} \mathrm{n} \mathrm{n}^{\mathrm{o}}$ 107.138/RS, julgado pela Primeira Turma, consiste em um caso de furto de uma bicicleta no valor de $\mathrm{R} \$ 150,00$ (cento e cinquenta reais). Os ministros, em decisão unânime, sustentam que apesar do paciente não ser tecnicamente reincidente, ele possui indicadores que demonstram uma personalidade criminosa para crimes contra o patrimônio ${ }^{199}$. Essa circunstância impede a aplicação do princípio da insignificância, visto que se macula um dos requisitos para a sua concessão (ausência de periculosidade do agente).

Percebe-se que a análise da relatora possui um viés incompleto, pois a afirmação de que há jurisprudência no Supremo Tribunal Federal vai de encontro aos argumentos de seu voto. Inicialmente, o que se pode sustentar é apenas a existência de jurisprudência da Primeira Turma, mas não da Suprema Corte.

Em segundo lugar, a ministra cita três habeas corpus: um que aborda um caso de furto tentado da Primeira Turma, outro sobre furto simples também da Primeira Turma e um sobre o crime de receptação julgado pela Segunda Turma. Sabe-se que a Primeira Turma possui uma posição consolidada tanto nos casos de furto simples tentado quanto de furto simples consumado em casos em que o paciente é reincidente. Desse modo, entende-se que a utilização de acórdãos da Primeira Turma afigura-se de modo tendencioso, pois não se pode defender o mesmo para a Segunda Turma.

Outro ponto de destaque é que a ministra usa como parâmetro de análise um caso de receptação que não comporta uma igualdade de tratamento em relação ao crime de furto. Apesar de apresentarem o mesmo quantitativo de pena e serem crimes contra o patrimônio, os ministros entendem que "o delito de receptação (art. 180, CP) traz consigo um enorme número de outros crimes, inclusive mais

\footnotetext{
${ }^{199}$ No caso do HC 107.138/RS o paciente havia sido beneficiado pela suspensão condicional do processo "sursis" da Lei 9.099/95 e durante o período de prova cometeu 4 (quatro) crimes da mesma espécie.
} 
graves $(\ldots)^{, 200}$.

Com relação ao aspecto deliberativo, não se constata que tenha ocorrido algum debate entre os ministros. Observa-se apenas que há a transcrição do voto da Ministra Relatora Cármen Lúcia, sendo que os Ministros Eros Grau e Teori Zavascki acompanharam o voto da relatora.

Por fim, a ementa traz a informação de que o réu é reincidente específico. No entanto, há a afirmação de que há precedentes de acordo com a decisão que foi proferida. Pondera-se que a possibilidade de precedentes é tão somente da Primeira Turma do STF.

\section{2 Resumo da análise dos casos de furto simples consumado}

Com base na análise das decisões selecionadas, elencam-se algumas ocorrências que ilustram a incoerência da Segunda Turma do Supremo Tribunal Federal no julgamento das decisões “A”, "B”, "C" " $D$ ” e “E”:

a) em nenhum dos casos em que há incoerência de votos, existe a fundamentação de posições que divergem entre si; isto é, sinaliza-se que os Ministros Ayres Britto, Ricardo Lewandowski, Gilmar Mendes e Joaquim Barbosa $^{201}$ votam de forma controversa, denegando a ordem em certos momentos e concedendo-a em outros; percebe-se que, em nenhum caso, há a transcrição de ambas as fundamentações dos votos que são contrários entre si;

b) em grande parte dos casos não há como se comparar os fundamentos das decisões, pois em sua maioria há apenas a transcrição do voto do relator; frisa-se que nas decisões "A", "B" e "E" há apenas a íntegra do voto do relator; por outro lado, a "Decisão C" é composta pela transcrição do voto do relator e de mais um ministro, enquanto na "Decisão D" há a reprodução do voto do relator e

\footnotetext{
${ }^{200}$ BRASIL, STF, $\mathrm{HC} \mathrm{n}^{\mathrm{o}}$ 111.608/RS, Rel. Min. Ricardo Lewandowski, Dje: 20.09.2012.

${ }^{201} \mathrm{O}$ "Quadro 03" demonstra de forma clara essa incoerência. Observa-se que os Ministros Ayres Britto, Ricardo Lewandowski, Gilmar Mendes, Joaquim Barbosa e Celso de Mello estão na coluna mais à esquerda sinalizados com o símbolo "•".
} 
mais dois ministros;

c) afirmações parciais de que há precedentes ou jurisprudência do STF;

d) em todos os casos o Superior Tribunal de Justiça considerou que a reincidência é um fator grave que exclui a aplicação do princípio da insignificância; fato este que demonstra que há jurisprudência com relação a esse tema no STJ;

e) votos que são embasados em acórdãos da Primeira Turma, fato este que empobrece o debate;

f) ministros que sustentam seus votos a partir de casos que não são semelhantes à questão que está sendo apreciada;

g) falta de diálogo entre os ministros;

h) a ementa dos julgados nem sempre reproduz, fielmente, o caso que está sendo julgado;

i) há ementas que afirmam, inadequadamente, que há precedentes que justificam a decisão tomada pela turma em um determinado julgamento, conforme decisões “A”, "B", “C”, "D” e "E".

\section{3}

Furto simples tentado

\subsection{1}

\section{"Decisão F"- HC n 106.510/MG}

Joaquim Barbosa vota pela denegação da ordem, fundamentando com base no $\mathrm{HC} \mathrm{n}^{\circ} 97.772 / \mathrm{RS}^{202-203}$, julgado pela Primeira Turma que não concede a ordem a um agente reincidente que tentou furtar roupas usadas e objetos avaliados em R $\$$

\footnotetext{
${ }^{202}$ BRASIL, STF, HC no 97.772/RS, Min. Rel. Cármen Lúcia, Dje: 20.11.2009.

${ }^{203}$ Frisa-se que o $\mathrm{HC} \mathrm{n}^{\circ}$ 97.772/RS não foi selecionado dentre os habeas corpus da Primeira Turma que tratam de casos de pacientes reincidentes que tenham cometido furto tentado "Quadro 02", pois a pesquisa optou por selecionar casos com características mais semelhantes possíveis, desconsiderando-se, assim, casos em que o furto foi mediante invasão de domicílio.
} 
143,00 (cento e quarenta e três reais).

Em seguida, Celso de Mello em um voto de 10 (dez) páginas transcreve várias ementas de acórdãos dos mais variados tipos penais, afirmando que o Supremo reconhece que é possível a aplicação do princípio da bagatela. Salientase que dos sete acórdãos transcritos pelo ministro, nenhum deles abarca algum caso em que o paciente fosse reincidente. Além disso, em momento algum abordou-se a reincidência em seu voto ${ }^{204}$.

O Ministro Celso encerrou sua votação afirmando que "com apoio no postulado da insignificância, e tendo em vista, ainda recente decisão proferida por esta colenda Turma no $\mathrm{HC} \mathrm{n}^{\mathrm{o}} 100.935 / \mathrm{RS}^{205}$, peço vênia para deferir a ordem de habeas corpus". O caso utilizado pelo ministro traz um caso de furto qualificado pela destruição ou rompimento de obstáculo e pelo concurso de pessoas (art. 155, $\S 4^{\circ}$, I e IV, CP), segundo o qual os pacientes haviam furtado bebidas avaliadas em $\mathrm{R} \$ 45,00$ (quarenta e cinco reais). Entende-se que o caso selecionado pelo ministro não é adequado para ser utilizado como fundamentação, visto que não se trata de um caso parecido.

Gilmar Mendes entende que a conduta é atípica, deferindo a ordem. Frisa que os ministros se encontram em um processo de construção sobre o tema e acredita que chegarão a um consenso futuramente, possivelmente com outras definições e outras participações ${ }^{206}$.

Houve um breve diálogo entre os ministros quanto ao regime penal que o paciente iria cumprir a pena. Visualiza-se que todos os julgadores presentes proferiram seus votos sem terem, em momento algum, acompanhado o voto do relator ou de outro colega.

Destaca-se que a ementa do acórdão não cita que o réu é reincidente. $\mathrm{A}$ seleção foi possível porque na indexação do acórdão há a citação do voto vencido

\footnotetext{
${ }^{204}$ Destaca-se o Ministro Celso de Mello ao final do julgamento, em um diálogo com os Ministros Ayres Britto e Joaquim Barbosa, questionou se o réu era reincidente, mas tão somente para verificar se seria possível a conversão da pena em restritiva de direitos (art. 44, inciso II, CP).

${ }^{205}$ BRASIL, STF, $\mathrm{HC}^{\circ}{ }^{\circ}$ 100.935/RS, Min. Rel. Celso de Mello, Dje: 17.09.2010.

${ }^{206}$ Nos casos selecionados neste ensaio, essa é a primeira vez que um Ministro expõe de forma clara esse problema que existe na Segunda Turma. Será abordado mais adiante, que na "Decisão H" o Ministro Gilmar Mendes propõe que os meios acadêmicos, o poder legislativo, juízes e tribunais se esforcem para viabilizar uma solução para essa questão.
} 
do ministro Joaquim Barbosa que suscita esse questionamento. Ademais, a ementa traz a expressão "considerações em torno da jurisprudência do STF”, o que denota um argumento equivocado, uma vez que não se pode considerar que há jurisprudência do Supremo que elucide essa questão ${ }^{207}$.

\subsection{2}

\section{"Decisão G"- HC n 108.872/RS}

Gilmar Mendes vota pela aplicação do princípio da insignificância, sustentando que o STF “em casos análogos tem reconhecido, inúmeras vezes, a possibilidade de aplicação do referido princípio". Observa-se que Mendes adotou a mesma posição da "Decisão F".

Em seguida, o ministro se vale de 3 (três) ementas de julgados do STF: a) HC $n^{0} 96.822 / \mathrm{RS}^{208}$ que trata de um caso de tentativa de furto em que houve concurso de pessoas e o criminoso não era reincidente; b) $H C n^{\circ} 97.189 / \mathrm{RS}^{209}$ aborda um caso de tentativa de furto no qual o paciente não é reincidente; c) $\mathrm{HC}$ $\mathrm{n}^{\mathrm{o}} 92.988 / \mathrm{RS}^{210}$ que cuida de uma tentativa de furto sendo que o agente não é reincidente.

A partir disso, entende-se que a argumentação do ministro é apresentada de modo incompleto, tendo em vista que não se pode considerar que os "casos análogos" selecionados pelo ministro são casos parecidos que podem ser utilizados como parâmetro na análise da "Decisão G". Sustenta-se que um argumento completo deveria se basear em casos que versem sobre a incidência ou não do princípio da insignificância a pacientes reincidentes que tenham praticado furto tentado.

Gilmar Mendes defende que "ao invocar a condição de reincidente do

\footnotetext{
${ }^{207}$ Entende-se que não se pode afirmar que há jurisprudência do STF que resolva a controvérsia sobre furto tentado em que os pacientes são reincidentes. Defende-se nesse trabalho que há tão somente jurisprudência da Primeira Turma, conforme decisões do "Quadro 02".

${ }^{208}$ BRASIL, STF, HC n 9 96.822/RS, Min. Rel. Cármen Lúcia, Dje: 07.09.2009.

${ }^{209}$ BRASIL, STF, HC n ${ }^{\circ}$ 97.189/RS, Min. Rel. Eros Grau, Dje: 14.08.2009.

${ }^{210}$ BRASIL, STF, HC n ${ }^{\circ}$ 92.988/RS, Min. Rel. Cezar Peluso, Dje: 26.06.2009.
} 
paciente como obstáculo à aplicação do princípio da insignificância, afastou-se da melhor jurisprudência sufragada por esta Corte". O HC n ${ }^{0} 191.954 / \mathrm{RS}^{211}$ do STJ em sua ementa afirmava que há precedentes tanto no STF quanto no STJ, no sentido de que a reincidência afasta a aplicação do princípio da insignificância. Sugere-se que tanto o ministro quanto a Quinta Turma do STJ argumentaram de modo equivocado, pois: a) o STJ só pode afirmar que há jurisprudência da Primeira Turma do STF no sentido de que a reincidência impede a incidência do princípio da insignificância; b) o Ministro Mendes analisa de modo parcial quando afirma que a decisão afastou a melhor jurisprudência do STF.

A “Decisão G” não é composta pela transcrição do voto do Ministro Ayres Britto, mas tão somente por sua inclinação em aplicar o princípio da insignificância. Considera-se que tanto o caso julgado por meio da "Decisão F" quanto pela "Decisão G" são casos parecidos que merecem o mesmo tratamento por parte dos ministros. Assim, é preciso deixar claro o motivo que o levou a votar de formar divergente da "Decisão F".

A votação não foi prestigiada por um diálogo entre os ministros. Há tão somente a transcrição do voto do relator, sendo que os demais ministros o

211 BRASIL. Superior Tribunal de Justiça. Habeas Corpus $\mathrm{n}^{\circ}$ 191.954/RS. Habeas corpus. Tentativa de furto. Res furtiva: cabos de cobre de para-raios avaliados em R\$100,00. Alta reprovabilidade da conduta. Inadmissibilidade da incidência do princípio da insignificância, no caso concreto. Paciente multireincidente em crimes contra o patrimônio. Precedentes do STF e STJ. Parecer do MPF pela denegação da ordem. Ordem Denegada. 1. O princípio da insignificância, que está diretamente ligado aos postulados da fragmentariedade e intervenção mínima do Estado em matéria penal, tem sido acolhido pelo magistério doutrinário e jurisprudencial tanto desta Corte, quanto do colendo Supremo Tribunal Federal, como causa supralegal de exclusão de tipicidade. Vale dizer, uma conduta que se subsuma perfeitamente ao modelo abstrato previsto na legislação penal pode vir a ser considerada atípica por força deste postulado.2. Entretanto, é imprescindível que a aplicação do referido princípio se dê de forma prudente e criteriosa, razão pela qual é necessária a presença de certos elementos, tais como (I) a mínima ofensividade da conduta do agente; (II) a ausência total de periculosidade social da ação; (III) o ínfimo grau de reprovabilidade do comportamento e (IV) a inexpressividade da lesão jurídica ocasionada, consoante já assentado pelo colendo Pretório Excelso (HC 84.412/SP, Rel. Min. CELSO DE MELLO, DJU 19.04.04).3. No caso em apreço, todavia, mostra-se de todo inaplicável o postulado permissivo, visto que evidenciada a alta reprovabilidade da conduta do paciente, sendo relevante anotar que é multireincidente em crimes contra o patrimônio, o que o STF tem considerado como fator relevante para o afastamento do referido princípio. (HC 103.359/RS, Rel. Min. CARMEN LÚCIA, DJe 05.08.2010).4. Ordem denegada, em conformidade com o parecer ministerial. Paciente: Jesus André Dutra Padua. Coator: Tribunal de Justiça do Rio Grande do Sul. Dje: $\quad$ 07.06.2011. Disponível em: $<\mathrm{http} / /$ www.stj.jus.br/webstj/processo/Justica/detalhe.asp?numreg=201002216106\&pv=01000000 0000\&tp=51>. Acesso em: 20 jan. 2013. 
acompanharam em seu voto. Tal fato empobrece o debate, pois ao menos Ayres Britto deveria se posicionar com relação à mudança de entendimento em relação à "Decisão F".

A ementa do acórdão não fala em reincidência, no entanto essa questão é abordada pelo ministro relator durante a exposição das razões de seu voto. Discorda-se da afirmação de que há "precedentes" no STF. Com base no "Quadro 02", demonstra-se que poderíamos falar na existência de precedentes da Primeira Turma do Supremo Tribunal Federal.

\subsection{3 \\ “Decisão H"- HC n 114.060/MG}

Alguns aspectos importantes consistem: a) na afirmação da Ministra Cármen Lúcia ao dizer que a denegação da ordem está de acordo com a jurisprudência consagrada pelo Supremo Tribunal Federal; b) no apontamento sobre o valor do crime de descaminho e sua relação com o princípio da insignificância; c) na colocação do Ministro Joaquim Barbosa ao dizer que o caso seria um crime de miserabilidade e d) ao destaque e importância da colocação do Ministro Gilmar Mendes ao frisar que essa questão tem que ser resolvida pelo Plenário do Supremo ou até pelo Congresso Nacional.

Cármen Lúcia vota no sentido da denegação da ordem de habeas corpus, confirmando o entendimento da Quinta Turma do Superior Tribunal de Justiça. A relatora pontua que a paciente é reincidente específica e que censuras anteriores não elidiram o retorno ao crime. Revela que a decisão do $\mathrm{STJ}^{212}$ está em harmonia com a jurisprudência do STF, citando trechos de 2 (dois) acórdãos que retratariam isso: o $\mathrm{HC} \mathrm{n}^{\mathrm{o}} 107.138 / \mathrm{RS}^{213}$ e o $\mathrm{HC} \mathrm{n}^{\mathrm{o}} 102.088 / \mathrm{RS}^{214}$, ambos da Primeira Turma do STF.

$\mathrm{O} \mathrm{HC} \mathrm{n}^{\circ} 107.138 / \mathrm{RS}$ trata de um caso de furto de uma bicicleta no valor

\footnotetext{
${ }^{212}$ BRASIL, STJ, HC n ${ }^{\circ}$ 234.493/MG, Rel. Min. Marco Aurélio Bellize, Dje: 13.06.2012.

${ }^{213}$ BRASIL, STF, HC n ${ }^{\circ}$ 107.138/RS. Rel. Min. Ricardo Lewandowski. Dje: 30.05.2011.

${ }^{214}$ BRASIL, STF, HC nº 102.088/RS. Rel. Min. Cármen Lúcia. Dje: 21.05.2010.
} 
de R \$ 150,00 (cento e cinquenta reais), no qual os ministros em decisão unânime sustentam que apesar do paciente não ser tecnicamente reincidente, possui indicadores que demonstram uma personalidade criminosa para crimes contra o patrimônio $^{215}$. Tal fator impede a aplicação do princípio da insignificância, pois não se atende a um dos seus requisitos, qual seja a ausência de periculosidade do agente.

Já o HC n ${ }^{\circ} 102.088 / R S$ versa sobre um caso em que o paciente foi preso, pois tentava furtar uma calça em uma loja, sendo que já tinha furtado outra calça em loja diferente. Os bens foram avaliados em $\mathrm{R} \$ 213,00$ (duzentos e treze reais). Os ministros, por votação unânime, denegaram a ordem, pois apesar dos bens serem de pequena monta, o paciente possuía extensa folha de antecedentes criminais, tendo inclusive, em outras ocasiões praticado furto, além de ter respondido uma ação penal por posse de drogas.

A afirmação de Cármen Lúcia é inadequada, pois não há jurisprudência do STF que solucione a questão que versa o caso em análise. Além disso, a ministra se valeu de acórdãos da Primeira Turma, fato este que reforça nosso ensaio quando afirmamos que somente há jurisprudência da Primeira Turma nessa matéria.

Já com relação ao voto de Barbosa dois apontamentos são feitos: a) quando o Ministro fala sobre a aplicação do princípio da insignificância pelo Estado ao crime de descaminho e b) não se compreende a distinção que o ministro realiza nesse julgamento declarando que o crime é de miserabilidade.

Sabe-se que é possível a aplicação do princípio da insignificância ao crime de descaminho e aos crimes de direito tributário. A Lei $\mathrm{n}^{\mathrm{o}} 10.522 / 02^{216} \mathrm{em}$ seu art. 20 dispõe que: "serão arquivados, sem baixa na distribuição, mediante requerimento do Procurador da Fazenda Nacional, os autos das execuções fiscais de débitos inscritos como Dívida Ativa da União pela Procuradoria-Geral da

\footnotetext{
${ }^{215}$ No caso do HC $107.138 /$ RS o paciente havia sido beneficiado pela suspensão condicional do processo "sursis" da Lei 9.099/95 e durante o período de prova cometeu 4 (quatro) crimes da mesma espécie.

${ }^{216}$ Dispõe sobre o cadastro informativo dos créditos não quitados de órgãos e entidades federais e dá outras providências.
} 
Fazenda Nacional ou por ela cobrados, de valor consolidado igual ou inferior a R \$ 10.000,00 (dez mil reais)". No entanto, no dia 22 de março de 2012 através da Portaria MF $\mathrm{n}^{\mathrm{o}} 75^{217}$ de março de 2012, alterou o patamar de $\mathrm{R} \$ 10.000,00$ (dez mil reais) para o valor de $\mathrm{R} \$ 20.000,00$ (vinte e mil reais).

A mudança ocorreu porque valores inferiores ao quantum estabelecido não saldariam o custo do processo judicial. Ressalta-se que essa modificação não significa uma impunidade para o réu, porque quando a dívida atingir valor acima dos R \$ 20.000,00 (vinte mil reais), a Fazenda ingressará com a execução fiscal.

Barbosa afirma em 25 de setembro de 2012 que "o Estado considera inofensiva, anódina a ação de descaminho no valor de até dez mil reais (...)", destacamos a modificação que houve através da Portaria $M F n^{0} 75$, de março de 2012 e da Portaria MF n ${ }^{\circ}$ 130, de abril de 2012 que modificaram o quantum de R $\$$ 10.000 (dez mil reais) para $\mathrm{R} \$ 20.000,00$ (vinte mil reais) para ingresso com a execução fiscal.

Além disso, a questão ainda é recente, sem contar que há uma sinalização de mudança ${ }^{218}$ tanto pelos Tribunais ${ }^{219-220}$ quanto por doutrinadores ${ }^{221}$ no que

${ }^{217}$ Dispõe sobre a inscrição de débitos na Dívida Ativa da União e o ajuizamento de execuções fiscais pela Procuradoria-Geral da Fazenda Nacional.

${ }^{218} \mathrm{O}$ cerne da questão levantada pelo Ministro Joaquim Barbosa que discordamos é a sua afirmação de que o Estado levaria em consideração na aplicação do princípio da insignificância a crimes da seara tributarista e aos crimes de descaminho o valor de $\mathrm{R} \$ 10.000,00$ (dez mil reais), fazendo referência indireta ao art. 20 da Lei $\mathrm{n}^{\circ} 10.522 / 02$. Indaga-se se a utilização da palavra "Estado" abarcaria todas as instituições que o compõe. Frisa-se que o Ministério da Fazenda leva em consideração do valor de $\mathrm{R} \$ 20.000,00$ (vinte mil reais) para ingressar com a execução fiscal.

${ }^{219}$ Grande parcela da doutrina entende que a tendência é que os Tribunais Superiores, no caso o Superior Tribunal de Justiça e Supremo Tribunal Federal tendem a considerar o patamar de R\$ 20.000,00 (vinte mil reais) no que tange à aplicação do princípio da insignificância em crimes tributários e de descaminho. O Supremo Tribunal Federal dá vestígios de que isso ocorrerá, como podemos observar com o Habeas Corpus $\mathrm{n}^{\circ}$ 118.000/PR: "Penal. Habeas Corpus. Crime De Contrabando. Princípio Da Insignificância. Aplicação. Impossibilidade. Reiteração Delitiva. Ordem Denegada. I - Nos Termos Da Jurisprudência Deste Tribunal, O Princípio Da Insignificância Deve Ser Aplicado Ao Delito De Descaminho Quando O Valor Sonegado For Inferior Ao Estabelecido No Art. 20 Da Lei 10.522/2002, Com As Atualizações Feitas Pelas Portarias 75 E 130, Ambas Do Ministério Da Fazenda. II - No caso sob exame, o paciente detinha a posse, sem a documentação legal necessária, de 22.500 (vinte e dois mil e quinhentos) maços de cigarro de origem estrangeira, que, como se sabe, é típica mercadoria trazida do exterior, sistematicamente, em pequenas quantidades, para abastecer um intenso comércio clandestino, extremamente nocivo para o País, seja do ponto de vista tributário, seja do ponto de vista da saúde pública. III - Os autos dão conta da reiteração delitiva, o que impede a aplicação do princípio da insignificância em favor do paciente em razão do alto grau de reprovabilidade do seu comportamento. IV - Ordem denegada."(Segunda Turma. Relator: Ministro Ricardo 
tange à aplicação do princípio da insignificância aos crimes tributários e de descaminho. Há decisões que aplicam o princípio da insignificância levando em consideração o novo patamar de R $\$ 20.000,00$ (vinte mil reais): TRF-4, ACR n 0003250-23.2009.404.7002/PR 222 ; TRF-4, ACR n ${ }^{\mathrm{o}} 0002157-25.2009 .404 .7002^{223}$ e TRF-3 ACR N ${ }^{\mathrm{o}} 0000072-84.2003 .4 .03 .6103 / \mathrm{SP}^{224}$.

Lewandowski. Dje: 17 de setembro de 2013. Disponível em: $<\mathrm{http}: / /$ redir.stf.jus.br/paginadorpub/paginador.jsp?docTP $=\mathrm{TP} \&$ docID $=4530826>$. Acesso em: 17 dez. 2013.

${ }^{220}$ Ressalta-se que tanto o STF e o STJ não possuem decisões no sentido da aplicação do princípio da insignificância a crimes de descaminho com base no novo valor estipulado pelas Portarias $75 \mathrm{e}$ 130 do MPF de 2012. Os respectivos Tribunais possuem decisões recentes aplicando o patamar antigo de R\$ 10.000,00 (dez mil reais). Decisões STJ: AgRg no AREsp 242049/PR, Min. Rel. Regina Helena Costa, Dje: 10.12.2013; AgRg no REsp 1275783/RS, Min. Rel. Regina Helena Costa, Dje: 13.12.2013. Decisões STF: HC 116242/RR, Rel. Min. Luiz Fuz, Dje: 17.09.2013; HC 115154/RS, Min. Rel. Luiz Fux, Dje: 16.08.2013.

${ }^{221}$ Como exemplo: Luiz Flávio Gomes, Alexandre Salim e Marcelo André de Azevedo. Ver: SALIM, Alexandre; AZEVEDO, Marcelo André de. Direito Penal- Parte Geral. $3^{\text {a }}$ edição. Salvador: Ed. Juspodivm, 2013.

${ }^{222}$ Tribunal Regional Federal- Quarta Região. Apelação Criminal no 0003250-23.2009.404.7002. Penal E Processo Penal. Descaminho. Questão De Ordem. Insignificância. Atipia. 1. A segurança jurídica da decisão esperada recomenda o prestigiamento dos precedentes, especialmente da Suprema Corte, a dar a solução definitiva em tema de tipicidade - na via do habeas corpus. 2. Adoção pela Seção Criminal desta Corte, na linha de precedentes do Supremo Tribunal Federal (HC92438 e HC95089) de que o desinteresse fazendário na execução fiscal torna certa a impossibilidade de incidência do mais gravoso e substitutivo direito penal. 3. É o limite de vinte mil reais, na forma do art. $2^{\circ}$ da Portaria $M F n^{\circ} 75$, de 22/03/2012, objetivamente indicador da insignificância para o crime de descaminho, ainda que reiterado (STF/HC 77003 e AI-QO 559904). 4. Atipia reconhecida em questão de ordem, pela reiteração jurisprudencial nesta Corte de tema exclusivamente de direito. Apelante: Gilmar de Almeida. Apelado: Ministério Público Federal. Relator: Desembargador Néfi Cordeiro. Sétima Turma. Foz do Iguaçu, PR. Dje: 13 de abril de 2012. Disponível em: $<\mathrm{http}: / /$ www2.trf4.jus.br/trf4/controlador.phpacao=consulta_processual_resultado_pesquisa\&txtV alor $=200970020032504 \&$ selOrigem $=$ TRF $\&$ chkMostrarBaixados $=\&$ todasfases $=\mathrm{S} \&$ selForma $=\mathrm{NU}$ \& todaspartes $=\&$ hdnRefId $=$ de1 cec1 e6326589de27b378a990aaae6\&txtPalavraGerada $=$ Gpto\&txtCh ave $=>$. Acesso em: 17 dez. 2013.

${ }^{223}$ Tribunal Regional Federal- Quarta Região. Apelação Criminal nº 0002157-25.2009.404.7002. PENAL. DESCAMINHO/CONTRABANDO. PRINCÍPIO DA INSIGNIFICÂNCIA. APLICAÇ̃̃O. Aplica-se o princípio da insignificância ao crime de descaminho, quando o valor do tributo não recolhido é igual ou inferior a $\mathrm{R} \$ \mathrm{R} \$ 20.000,00$ (vinte mil reais), patamar esse instituído pelo art. $1^{\circ}$, II, da Portaria MF n 75 de 22/03/2012. Apelante: Alexsandro Giembra Apelado: Ministério Público Federal. Relator: Desembargador Luiz Fernando Wowk Penteado Oitava Turma. Foz do Iguaçu, PR. Dje: 30 de maio de 2012. Disponível em: $<$ http://www2.trf4.jus.br/trf4/controlador.phpacao $=$ consulta_processual_resultado_pesquisa\&txtPa lavraGerada $=$ rHZX\&hdnRefId=46a7b323d5781e6ffafce0db0b517b54\&selForma=NU\&txtValor= $00021572520094047002 \&$ chkMostrarBaixados $=\&$ todasfases $=\&$ todosvalores $=\&$ todaspartes $=\&$ txt DataFase $=\&$ selOrigem $=$ TRF $\&$ sistema $=\&$ codigoparte $=\&$ txtChave $=\&$ paginaSubmeteuPesquisa $=$ let ras>. Acesso em: 17 dez. 2013.

${ }^{224}$ Tribunal Regional Federal- Terceira Região. Apelação Criminal $\mathrm{n}^{\circ}$ 000007284.2003.4.03.6103/SP. Penal. Sonegação De Contribuição Previdenciária. Artigo 337-A, I, Do Código Penal. Preliminares De Nulidade E Prescrição Rejeitadas. Princípio Da Insignificância. 
Em conclusão, temos o voto do Ministro Gilmar Mendes que aponta que há uma disparidade nos julgamentos da Primeira Turma e da Segunda Turma do Supremo Tribunal Federal. É justamente esse o objetivo desta pesquisa, notar que com relação à possibilidade de aplicação ou não do princípio da insignificância a réus reincidentes não podemos falar que há jurisprudência do STF que ilustre de forma clara essa questão. Muito pelo contrário, há uma "zona cinzenta" no que diz respeito tanto às decisões da Segunda Turma quanto à dissonância de votos dos próprios ministros nos julgados selecionados ${ }^{225}$. Já com relação aos julgamentos proferidos pela Primeira Turma, pode-se cogitar que há jurisprudência, uma vez que seus julgamentos têm sido no sentido da não aplicação do princípio da insignificância a réus reincidentes que praticaram furto simples tentado.

Mendes, em momento algum, aponta que os julgamentos da Primeira

\begin{abstract}
Absolvição. Recurso Parcialmente Prejudicado. 1. A norma processual brasileira é regida pelo princípio tempus regit actum, de modo que a novel legislação processual tem aplicação imediata após a sua entrada em vigor sem o condão de invalidar os atos realizados na forma prescrita pela lei anterior (CPP, artigo $2^{\circ}$ ). Nesta linha, mácula não há no processamento do presente feito, uma fez que o interrogatório do réu se deu em momento processual muito anterior à entrada em vigor da Lei $n^{\circ} 11.719$, editada em 20 de junho de 2008, não sendo imperiosa a renovação do ato válido. Preliminar de nulidade processual rejeitada. 2. A sentença foi proferida conforme a lei e se encontra devidamente fundamentada. $\mathrm{O}$ magistrado de primeiro grau atribuiu ao litígio conclusão baseada em farto conjunto de provas colhidas durante toda a instrução processual, inclusive no depoimento de testemunha de defesa, daí porque não há que se falar em nulidade da sentença exarada exclusivamente com supedâneo em provas ordenadas na fase inquisitorial. Preliminar de nulidade da sentença que também se rejeita. 3. Como cediço, após o trânsito em julgado da sentença condenatória para a acusação, a prescrição regula-se pela pena aplicada na sentença (artigo $110, \S 1^{\circ}$, do CP), de acordo com os prazos determinados no artigo 109 do Código Penal, não se computando o acréscimo decorrente da continuidade delitiva (Súmula 497 do STF). 4. Cotejando-se os marcos interruptivos da prescrição, constata-se que não decorreu o lapso prescricional. Preliminar de prescrição rejeitada. 5. O réu foi condenado pela prática do delito previsto no artigo 337-A, I, CC. o artigo 71, ambos do Código Penal. 6. Aplicação do princípio da insignificância. $\mathrm{O}$ valor da contribuição previdenciária não recolhida, afastados juros de mora e multa, é inferior àquele previsto como o valor mínimo executável ou que permite o arquivamento, sem baixa na distribuição, das execuções fiscais de débitos inscritos como Dívida Ativa da União, nos termos do artigo 20 da Lei n. 10.522/2002 e da na Portaria $n^{0}$ 75/2012 do Ministério da Fazenda, a qual elevou o referido montante para $\mathrm{R} \$ 20.000,00$ (vinte mil reais). 7. Matéria preliminar rejeitada. No mérito, Decretada A Absolvição Do Réu Diante Da Atipicidade Material Da Conduta. No Mais, Prejudicado O Exame Do Recurso. Apelante: Richard Gunther Sutherland Wurzler Apelado: Justiça Pública. Relatora: Desembargadora Federal Vesna Kolmar. Terceira Vara. São José Dos Campos, SP. Dje: 22 de janeiro de 2013. Disponível em: $<$ http://web.trf3.jus.br/acordaos/Acordao/BuscarDocumentoGedpro/2435991 >. Acesso em: 17 dez. 2013.

${ }^{225}$ Note que no "Quadro 04" os Ministros Ayres Britto e Joaquim Barbosa possuem posições incoerentes em casos parecidos, estando ambos identificados na coluna mais à esquerda pelo símbolo "»".
\end{abstract}


Turma estariam pautados por uma harmonia que indicaria a existência de jurisprudência tão somente dessa Turma. O ministro propõe não só uma maior atenção ao tema pelo Supremo, mas também de outras instâncias, como juízes e tribunais para que se esforcem na busca de um critério de uniformização de julgamento. Outra proposta seria uma consideração dessa matéria por parte do Congresso Nacional, através de uma reflexão legislativa e, igualmente, através dos meios acadêmicos.

Compartilha-se a posição de Gilmar Mendes, destacando que essa foi a segunda oportunidade em que o ministro indica que há um problema na sistemática das votações ${ }^{226}$ nos casos elencados no "Quadro 04".

Gilmar Mendes levanta uma série de questões importantes que merecem a atenção. Após isso, há um breve debate que não contribui para a resolução da questão entre os ministros.

Observa-se que todos os ministros proferiram seu voto e dialogaram em certa medida. No entanto, o debate foi prejudicado pelas posturas dos ministros que não acolheram as reivindicações do Ministro Mendes. Entende-se que seria uma boa oportunidade para se aplicar o Art. 22, parágrafo único, "a" do RISTF que estabelece: "o Relator submeterá o feito ao julgamento do Plenário, quando houver relevante arguição de inconstitucionalidade ainda não decidida. Parágrafo único. Poderá o relator proceder na forma deste artigo: a) quando houver matérias em que divirjam as Turmas entre si ou alguma delas em relação ao Plenário".

Por fim, ressalta-se que a ementa do acórdão não cita que a paciente era reincidente. Nesse caso, a busca foi possível porque na indexação do acórdão havia a citação da reincidência do agente. Além disso, a ementa não afirma como nos outros julgados, que haveria precedentes ou jurisprudência do STF em torno do assunto.

\footnotetext{
${ }^{226} \mathrm{Na}$ "Decisão F" o Ministro Gilmar Mendes destaca que acredita que os Ministros chegarão a um consenso sobre essa questão futuramente.
} 


\subsection{4 \\ "Decisão l"- HC no 113.782/RS}

Decisão composta apenas pelo voto integral do Ministro Relator Ricardo Lewandowski. O ministro vota pena denegação da ordem acompanhando, assim, o mesmo posicionamento da "Decisão H". Em passagem de seu voto, Lewandowski ao considerar o elemento da reincidência no julgamento do caso em tela, salienta que ${ }^{227}$ :

Esta Turma apresentava certa divergência quanto a considerar as questões relativas à pessoa do agente no exame da incidência ou não do princípio da insignificância ao caso concreto, por serem atinentes à culpabilidade, e não à tipicidade. Contudo, a partir do voto-vista proferido pelo Ministro Teori Zavascki no RHC 115.226/MG, Rel. Min. Cármen Lúcia, a Turma, por maioria, firmou entendimento no sentido dessa possibilidade.

O RHC n ${ }^{\circ} 115.226 / \mathrm{MG}^{228}$ aborda um caso de um criminoso contumaz que pratica estelionato. O recurso foi julgado pela Segunda Turma no dia 14 de maio de 2013, sendo que os ministros, por maioria, votaram pelo não provimento do recurso. Participaram da votação os ministros: Cármen Lúcia (Relatora), Teori Zavascki, Ricardo Lewandowski, que negaram o recurso e os Ministros Celso de Mello e Gilmar Mendes que deram provimento.

227 Após essa afirmação, o Ministro Lewandowski transcreve parte do inteiro teor do RHC 115.226/MG: "para se afirmar que a insignificância pode conduzir à atipicidade, cumpre, portanto, que se vá além da irrelevância penal a que se referiu o legislador. É indispensável averiguar o significado social da ação, a adequação da conduta do agente em seu sentido social amplo, a fim de que se apure se o resultado dessa investigação ampliada é compatível ou não com a finalidade perseguida pelo ordenamento penal, ou, em outras palavras, se o fato imputado, que é formalmente típico, tem ou não, quando examinado no seu contexto social, relevância penal. Parece certo concluir, à luz dessas premissas que a relevância penal, em casos dessa natureza, comporta, sim, juízo sobre a contumácia da conduta do agente".

${ }_{228}$ BRASIL. Supremo Tribunal Federal. RHC no 115.226/MG. Recurso ordinário em habeas corpus. Constitucional. Penal. Estelionato. Pretensão de aplicação do princípio da insignificância. Impossibilidade. Processos em curso por outros delitos praticados pelo recorrente. Propensão à prática delitiva. 1. Para a incidência do princípio da insignificância, devem ser relevados o valor do objeto do crime e os aspectos objetivos do fato, tais como, a mínima ofensividade da conduta do agente, a ausência de periculosidade social da ação, o reduzido grau de reprovabilidade do comportamento e a inexpressividade da lesão jurídica causada. 2. Nas circunstâncias do caso, não se pode aplicar ao Recorrente o princípio em razão de outras práticas de crimes por ele, de roubo inclusive. 3. Recurso ao qual se nega provimento. Recorrente: André Henrique Campos. Recorrido: Ministério Público Federal. Relator: Ministra Cármen Lúcia. Brasília, DF. Dje: 21 nov. $2013 . \quad$ Disponível em: $<$ http://redir.stf.jus.br/paginadorpub/paginador.jsp?docTP=TP\&docID=4893880>. Acesso em: 22 jan. 2013. 
Lewandowski no julgamento da "Decisão I" afirma que a Segunda Turma firmou entendimento no sentido de que se devem levar em consideração questões relativas à pessoa do agente na análise da possibilidade de aplicação do princípio da insignificância. Depreende-se a partir do inteiro teor do RHC no 115.226/MG na retificação de voto do Ministro Gilmar Mendes que o caso concreto versa sobre um criminoso contumaz e não reincidente. Frisa-se que o Ministro Zavascki, em seu voto, ressalta essa distinção entre a contumácia e a reincidência ${ }^{229}$.

O RHC $n^{\circ} 115.226 / \mathrm{MG}$ aborda um caso de agente que é contumaz e não reincidente. Sua ementa à primeira vista, nos dá a impressão que o paciente é reincidente, no entanto, ele é contumaz. A ementa cita "propensão à prática delitiva e também que nas circunstâncias do caso, não se pode aplicar ao Recorrente o princípio em razão de outras práticas de crimes por ele, de roubo inclusive". Tanto a Ministra Cármen Lúcia quanto o Ministro Teori Zavascki ressaltam a peculiaridade da contumácia em seus votos.

Lewandowski, no voto da "Decisão I" afirma que a partir do RHC n 115.226/MG firmou-se o entendimento de que se deve levar em consideração a reprovabilidade da conduta nos casos em que o paciente possui acentuada periculosidade, fazendo do crime um meio de vida.

A postura adotada pelo Ministro Lewandowski não foi adequada, pois não há como se afirmar que a Segunda Turma firmou entendimento de que

\footnotetext{
${ }^{229}$ No julgamento do RHC 115.226/MG o Ministro Teori Zavascki ressalta que: "a hipótese de contumácia que, num juízo de tipicidade conglobante, afasta a aplicação do princípio da insignificância é da multirreincidência ou reiteração cumulativa de condutas do mesmo gênero". Em outro trecho de seu voto, o Ministro Zavascki menciona os ensinamentos de Luiz Flávio Gomes ao afirmar que a respeito da multireincidência ou reiteração cumulativa: "parece-nos muito acertado afirmar que a multirreincidência (de algo em princípio irrelevante) pode elevar o fato para patamar relevante, deixando de ter validade o princípio da insignificância. Em outras palavras, quando o agente pratica reiteradas condutas que, somadas, não geram um resultado insignificante (sim, bastante expressivo), deixa de ter pertinência o princípio que estamos estudando. Gerente de banco (ou um "hacker") que desvia R $\$ 1,00$ de cada conta corrente, no final, aufere soma significativa. Empregado que trabalha como caixa de estabelecimento comercial e que furta, diariamente, pequena quantidade de dinheiro. Para efeito da pena e da aplicação do princípio da insignificância temos que considerar o todo como fato único. Com isso fica refutada a aplicação na doutrina da insignificância quando o agente, mediante reiteradas condutas, acaba lesando seriamente o bem jurídico (...)".O Ministro Zavascki direciona essa passagem como sendo de autoria do Doutrinador Luiz Flávio Gomes, indicando inclusive, as páginas (p. 112/115), porém não faz referência à obra que foi utilizada.
} 
considerações subjetivas do paciente devem ser levadas em consideração, pois:

a) os casos são diferentes. Apesar de tratarem do exame da incidência ou não do princípio da insignificância, a "Decisão I" trata de um agente que cometeu furto tentado e é reincidente, enquanto a o RHC $n^{\circ} 115.226 / \mathrm{MG}$ versa sobre um paciente que praticou estelionato e é contumaz;

b) afirmar que a Turma "firmou entendimento" demonstra uma acepção parcial do ministro relator, tendo em vista que a decisão não foi unânime.

Finalmente, a ementa da "Decisão I" cita que o agente seria reincidente. Além disso, não faz referência de que haveria jurisprudência ou precedentes do Supremo Tribunal Federal que solucionariam a questão tratada.

\section{4 Resumo da análise dos casos de furto simples tentado}

A partir da análise das decisões selecionadas, elencam-se algumas ocorrências que ilustram a incoerência da Segunda Turma do Supremo Tribunal Federal no julgamento das decisões "F", "G", "H" e "I":

a) os voto do Ministro Ayres Britto conflitam entre si; o Ministro Britto denegou a ordem na "Decisão F", enquanto na "Decisão G" a concedeu; há apenas a transcrição do voto na "Decisão "F", fato este que impossibilita uma comparação entre as fundamentações;

b) outra contradição é apresentada a partir do voto do Ministro Joaquim Barbosa, pois na "Decisão F" denega a ordem e na "Decisão H" a concede; o Ministro Barbosa na "Decisão F" destaca em seu voto que o paciente é reincidente; já na "Decisão $H$ " entende que o crime é de miserabilidade ${ }^{230}$; percebe-se que há um falso distinguishing por parte do ministro, visto que a paciente furtou óleos de amêndoa, enxaguantes bucais, chupetas e hidratante que

${ }^{230}$ Destaca-se que Ministra Cármen Lúcia frisa que essa situação não condiz com a realidade, pois a paciente havia furtado objetos semelhantes em outras ocasiões, uma vez que em sua ficha de antecedentes criminais há crimes de furto e roubo. $\mathrm{O}$ fato da Ministra Cármen ter alertado o Ministro Barbosa para a qualificação inadequada que fez do caso e a permanência de sua postura, indica que o Ministro Barbosa denotou uma significação parcial do caso. 
não configuram um estado de pobreza absoluta da agente;

c) afirmações parciais de que há precedentes ou jurisprudência do STF;

d) todos os julgamentos do Superior Tribunal de Justiça consideraram a reincidência como um obstáculo à aplicação do princípio da insignificância;

e) votos que são embasados em acórdãos da Primeira Turma, empobrecendo, assim, o debate;

f) ministros que sustentam seus votos a partir de casos que não são semelhantes à questão que está sendo apreciada;

g) dos 4 (quatro) casos analisados, em 2 (dois) há apenas a íntegra do voto do relator, demonstrando que a deliberação entre os ministros não foi prestigiada;

h) a ementa dos julgados nem sempre reproduz de modo fiel o caso que está sendo julgado;

i) há ementas que afirmam, indevidamente, que há precedentes que justificam a decisão tomada pela Turma em um determinado julgamento, conforme decisões "F" e "G". 


\section{5 \\ Resultados da pesquisa}

A presente pesquisa empírica confirmou algumas observações a respeito do Supremo Tribunal Federal apontadas por estudiosos do Direito, como: a) incoerência nas fundamentações das decisões quando se compara casos semelhantes que possuem tratamento diferenciado pelos ministros; b) decisões que são julgadas por um órgão colegiado, que apresentam essência de decisão monocrática, possuindo apenas a fundamentação do voto do relator; c) argumentos levantados durante o debate que são ignorados pelos demais ministros, demonstrando, assim, pouco apreço pela deliberação; d) votos prolixos e eruditos e f) a inexistência de uma jurisprudência genuína.

Com relação à incoerência nas fundamentações das decisões de casos semelhantes, observou-se que alguns ministros dão um tratamento diferenciado a casos semelhantes. Demonstra-se a ocorrência de votos incoerentes nos casos de furto consumado por parte dos Ministros Ayres Britto (decisões "B" e "C"), Ricardo Lewandowski (decisões “C” e "D”), Gilmar Mendes (decisões "B”, "C", “D” e "E”), Joaquim Barbosa (decisões “A", "B" e "D”) e Celso de Mello (decisões "A", "B", "C" e "D"). Nos casos de furto tentado, novamente os Ministros Ayres Britto (decisões "F" e "G") e Joaquim Barbosa (decisões "F" e "H”) assumem essa postura.

Tratar casos semelhantes desse modo não é o comportamento esperado e defendido pela presente pesquisa. Com base nos argumentos defendidos a partir da coerência, segurança jurídica, estabilidade, previsibilidade das decisões, despersonalização das demandas, consistência, replicabilidade e necessidade de legislar, considera-se reprovável essa conduta.

Dos nove casos analisados, em cinco deles (decisões "A", "B", "E”, “G” e 
"I") houve somente a transcrição do voto do relator e todos os demais votos foram apenas registrados em ata. Já na decisão "C" dois ministros votaram e anexaram seus votos na íntegra, enquanto na decisão "D” três ministros.

No tocante aos votos prolixos e uso de vocabulários eruditos, das 9 (nove) decisões da Segunda Turma, 7 (sete) ${ }^{231}$ delas possuíam mais de 10 (dez) páginas, em 3 (três) ${ }^{232}$ delas houve a citação de doutrina, sendo em ambas as ocorrências por parte do Ministro Gilmar Mendes. Em alguns casos, a leitura do acórdão se torna ainda mais cansativa, havendo citações e transcrições do mesmo acórdão, como ocorre na "Decisão C" fato este constatado no voto do Ministro Gilmar Mendes. Em outros, observa-se que tanto para a fundamentação dos casos de furto consumado quanto para o de furto tentado, utilizaram-se exatamente as mesmas citações e transcrições de habeas corpus, conforme se comprova no voto do Ministro Joaquim Barbosa ${ }^{233}$ nas decisões "B", "D" e "F" e também no voto da Ministra Cármen Lúcia ${ }^{234}$ nas decisões "E" e " $F$ ".

Muitos votos carecem de densidade argumentativa, tentando de algum modo, impressionar o leitor com o uso de vocabulários eruditos e afirmações que tentam comovê-lo, induzindo a acreditar que a questão já está pacificada. Dos 9 (nove) casos selecionados, em 8 (oito) deles foi constatado o uso de "lugarescomuns"235 como: "colho lições da doutrina" e "precedente desta Corte" ("Decisão B"), "esta Suprema Corte consolidou o entendimento no sentido de que" ("Decisão C"), "precedente desta Corte" e "atesto que a jurisprudência desta

\footnotetext{
${ }^{231}$ Decisões "C", "D", "E", "F", "G", "H" e "I", tendo, respectivamente, 24 (vinte e quatro), 14 (quatorze), 12 (doze), 23 (vinte e três), 13 (treze), 25 (vinte e cinco) e 11 (onze) páginas.

${ }^{232}$ Decisões "C" e "G": Gilmar Mendes citou os doutrinadores citados foram: Cezar Roberto Bitencourt, Rogério Greco e Damásio de Jesus. Decisão "F": Celso de Mello citou Francisco de Assis Toledo, Cezar Roberto Bitencourt, Damásio de Jesus e Maurício Antônio Ribeiro Lopes, Edilson Mougenot Bonfim, Fernando Capez e René Ariel Dotti.

${ }^{233} \mathrm{Em}$ todos os três casos, houve a citação do $\mathrm{HC} \mathrm{n}^{\circ}$ 100.240/RJ (Segunda Turma, Rel. Min. Joaquim Barbosa, Dje: 07.12.2010) e a transcrição do $\mathrm{HC} \mathrm{n}^{\circ}$ 97.772/RS (Primeira Turma, Rel. Min. Cármen Lúcia, Dje: 20.11.2009).

${ }^{234}$ A Ministra Cármen Lúcia usou a transcrição do mesmo habeas corpus, no caso, o $\mathrm{HC}^{\circ}$ 107.138/RS (Primeira Turma, Ministro Ricardo Lewandowski, Dje: 30.05.2011).

${ }^{235}$ Considera-se que tais expressões se tornaram de uso trivial por parte dos ministros. Com relação às expressões que afirmam haver precedentes e jurisprudência, entende-se que a afirmação deveria ser reformulada e indicar que a Primeira Turma do STF possui um entendimento definido com relação a essa matéria. $\mathrm{O}$ uso indiscriminado desses dois termos faz entender que a questão já estaria definida em todo o Supremo Tribunal Federal.
} 
Corte tem sido no sentido" (“Decisão D”), “decisão do STJ está em harmonia com a jurisprudência do Supremo Tribunal Federal" (“Decisão E”), “transcrevo precedente desta Corte" e "consoante assinala expressivo magistério doutrinário expendido na análise do tema em referência" ("Decisão F"), "colho precedentes desta Corte" e "colho lições da doutrina" ("Decisão G”), “decisão do STJ está em harmonia com a jurisprudência do Supremo Tribunal Federal" ("Decisão H") e "firmou entendimento" ("Decisão I").

Há um apelo por meio de citações e transcrições torrenciais de julgados anteriores, como se observa, por exemplo, nos votos do Ministro Gilmar Mendes. Além disso, sublinham-se dois aspectos: a) grande parte dos acórdãos citados no início do voto foram novamente referidos, tendo sua ementa transcrita no final e b) os habeas corpus citados e transcritos, na maioria das vezes, não guardam relação de semelhança com o caso sob julgamento. Nesse aspecto, Rodriguez expõe a existência de "argumentos de autoridade" 236 , predominando "no Brasil a articulação de opiniões acompanhadas da citação, sem contextualização ou análise, de uma série de 'jurisprudências' e 'doutrinas' a título de argumento de autoridade". 237

O fundamento das decisões está, assim, alicerçado por opiniões pessoais que apresentam uma roupagem de parecer jurídico. O debate é relegado sendo substituído por argumentos parciais e acúmulo de opiniões. Depreende-se que

\footnotetext{
${ }^{236}$ Rodriguez define que "uma argumentação fundada em argumentos de autoridade (..) não tem o dever de demonstrar a coerência entre leis, casos e doutrinadores que cita. Com efeito, ela não se sente limitada por nenhum ônus argumentativo. Seu único compromisso é com a eficácia em convencer o destinatário, podendo-se utilizar para este fim qualquer argumento, qualquer elemento, qualquer estratagema. O que importa é a obtenção de uma solução, de uma decisão e não o padrão argumentativo que a fundamente. Neste tipo de argumentação, a pessoa que toma a decisão e a decisão em si mesma são mais importantes do que o raciocínio desenvolvido para se chegar nela. Ao argumentar, a pessoa da autoridade expõe os motivos pelos quais foi convencida de determinada solução jurídica. Se o caso for simples e não gerar controvérsia entre cidadãos e autoridades, sua justificação será extremamente sucinta, mais centrada no resultado do que em sua justificação. Em casos cuja decisão resulte de votações unânimes, a fundamentação tenderá a assumir tais feições. De outra parte, se estivermos diante de casos que gerem controvérsia, haverá a invocação de autoridades para corroborar a posição do responsável por tomar a decisão. De qualquer forma, o objetivo da autoridade não é, nesse registro, argumentar em nome da melhor solução possível para o caso, mas sim apresentar as razões pelas quais formou sua opinião pessoal sobre qual deva ser a melhor solução para o caso". RODRIGUEZ, José Rodrigo. Como Decidem as Cortes? Para uma Crítica do Direito (Brasileiro). Rio de Janeiro: Ed. FGV, 2013, p. 73-74.

${ }^{237}$ RODRIGUEZ, José Rodrigo. Op. cit., p. 77
} 
essa postura cria um efeito inter partes nas decisões, pois se trata casos parecidos de forma diferente.

Por fim, a pesquisa indica a inexistência de uma jurisprudência genuína (leia-se: strictu sensu) no Supremo Tribunal Federal com relação ao tema selecionado. Não há o objetivo de se generalizar e dizer que não há jurisprudência no Supremo Tribunal Federal. Uma afirmação como essa é equivocada.

A pesquisa investigou posturas incoerentes no processo decisório do STF com base nos informativos $n^{\circ} 573$ a 732 que compreendem os períodos de fevereiro de 2010 a dezembro de 2013, ou seja, a análise se baseou em 160 (cento e sessenta) informativos. $\mathrm{O}$ estudo traçou critérios que foram seguidos na análise de todos os julgamentos que, de algum modo, demonstravam prima facie possuir algum tipo de incoerência no julgamento dos demais casos parecidos ${ }^{238}$.

A exposição desse trabalho sugere: a) a incoerência das decisões quando se compara casos semelhantes, b) decisões colegiadas essencialmente monocráticas, c) pouco apreço pela deliberação, d) votos prolixos e eruditos e e) caráter personalista e opinativo nas votações que demonstram serem sintomas que refletem a inexistência de uma jurisprudência genuína como a do tema selecionado.

Nota-se um descompromisso com a utilização da palavra "jurisprudência" e também com seu significado. Não se pode usá-la de modo leviano como muitos operadores do direito fazem para abrilhantar o discurso, demonstrando um "argumento de autoridade" que poderia de algum modo convencer, infalivelmente, o leitor.

Aponta-se que a estrutura da ementa, muitas vezes, não traduz o que ocorreu no julgamento, além de omitir, em algumas vezes, características importantes do caso. Isso pode ser um problema. Durante a análise dos informativos, detectou-se que a aferição das decisões apenas pela leitura das

\footnotetext{
${ }^{238}$ Casos que a pesquisa analisou que demonstravam, inicialmente, algum tipo de incoerência decisória: a) possibilidade de segunda chamada em concursos públicos que exigem prova de aptidão física, b) crime de porte/posse de arma de fogo e munição, c) concurso público: mérito das questões e anulação e d) utilização de bens apreendidos pelas polícias estaduais. Frisa-se que as hipóteses foram eliminadas, pois se confirmou que a incoerência, muitas vezes, surgiu porque a ementa da decisão não era clara, gerando, assim, dúvidas a respeito do tema.
} 
ementas pode gerar a ideia de que não há jurisprudência, mas sim um emaranhado de decisões que, muitas vezes, não faz sentido.

Nos casos em que houve a transcrição de um voto, e todos os outros foram votos de "mero acompanhamento", a situação se agrava, pois a ementa será construída apenas com os argumentos sustentados pelo relator. A ementa deve ser clara, englobar as principais características do caso sob julgamento e deve refletir a decisão do tribunal.

Outro aspecto relevante é a forma pela qual a citação dos casos é feita nos votos:

A citação de casos, quando ocorre, não busca reconstruir um padrão de argumentação relevante para o caso a ser decidido. Os casos são citados em forma de acúmulo para reforçar a autoridade de quem está proferindo a sentença. É muito difícil encontrar casos que sirvam de referência para todos os juízes no que diga respeito a um mesmo problema jurídico. ${ }^{239}$

Intiga-se uma reflexão com base nos argumentos aqui expostos. $\mathrm{O}$ tema "possibilidade de aplicação ou não do princípio da insignificância a pacientes reincidentes" desperta grande curiosidade e inquietação com relação ao tratamento diferenciado que foi atribuído por alguns ministros. $\mathrm{O}$ dito popular "cada cabeça, uma sentença" parece se encaixar aos habeas corpus, pois além de cada ministro tratar a matéria de modo diverso, pode um mesmo ministro dependendo do seu "juízo" decidir casos parecidos de modo incoerente, não respeitando seus autoprecedentes.

${ }^{239}$ Rodriguez, José Rodrigo. Op. cit., p. 107. 


\section{6 \\ Conclusão}

Com base na leitura de livros e artigos, questionou-se se haveria ou não decisões harmônicas que delineariam um corpo jurisprudencial genuíno. Com base nessa indagação, foi traçada uma investigação a partir de informativos jurisprudenciais do Supremo Tribunal Federal, objetivando comprovar incoerências no processo decisório.

A análise foi feita a partir dos informativos $n^{0} 573$ a 732 que compreendem os períodos de fevereiro de 2010 a dezembro de 2013. Além, dos 160 (cento e sessenta) informativos analisados, inclui-se na investigação da hipótese decisões esparsas do Supremo ${ }^{240}{ }_{-}^{241}$. O exame compreendeu decisões com trânsito em julgado em sede de controle difuso de constitucionalidade, em sede de controle concentrado de constitucionalidade, ou seja, ações declaratórias de constitucionalidade (ADCs), ações diretas de inconstitucionalidade (ADIs), e arguições de descumprimento de preceito fundamental (ADPFs), além de habeas corpus $^{242}$.

Descobriu-se que nos habeas corpus que versavam sobre a possibilidade ou não de aplicação do princípio da insignificância em réus reincidentes que

\footnotetext{
${ }^{240}$ Destaca-se que em alguns casos, a ementa dos julgados fez com que se criasse a ideia de que em casos semelhantes, a decisão era incoerente. Nesse caso, sempre quando isso era detectado, recorria-se ao inteiro teor dos julgados, a fim de se revelar qual era a posição do Supremo naquele caso.

${ }^{241}$ Com base nos seguintes informativos e habeas corpus do Supremo Tribunal Federal: informativo $\mathrm{n}^{\circ} 610$ de novembro de 2010 ( $\mathrm{HC} \mathrm{n}^{\circ} 101.998 / \mathrm{MG}$, Primeira Turma), informativo $\mathrm{n}^{\circ}$ 620 de março de 2011 ( $\mathrm{HC} \mathrm{n}^{\circ}$ 106.510/MG, Segunda Turma), informativo $\mathrm{n}^{\circ} 657$ de março de $2012\left(\mathrm{HC} \mathrm{n}^{\circ}\right.$ 108.969/MG, Primeira Turma) e informativo $\mathrm{n}^{\circ} 667$ de maio de $2012\left(\mathrm{HC} \mathrm{n}^{\circ}\right.$ 109.870/RS, Segunda Turma) visualizou-se uma incoerência no julgamento de casos parecidos.

${ }^{242} \mathrm{O}$ exame desconsiderou recursos ordinários em habeas corpus, agravos regimentais em habeas corpus, habeas corpus que não foram conhecidos e habeas corpus que estavam aguardando votovista.
} 
praticaram tanto furto simples consumado quanto furto tentado, a Primeira Turma do STF possuía uma posição clara e definida, enquanto a Segunda Turma possuía decisões diferentes. Ou seja, em alguns casos concedia a ordem, em outros, denegava a ordem, sem que fosse realizado um distinguishing, overruling, overriding ou transformation.

O "Quadro 03" aborda os casos de furto consumado da Segunda Turma. Nos 5 (cinco) habeas corpus ( $\mathrm{HC} \mathrm{n}^{\circ}$ 93.393/RS, HC $\mathrm{n}^{\circ}$ 97.007/SP, HC $\mathrm{n}^{\circ}$ 107.184/RS, HC $\mathrm{n}^{\mathrm{o}}$ 109.870/RS e $\mathrm{HC} \quad \mathrm{n}^{\circ}$ 118.089/MG), denominados respectivamente, de decisões "A", "B", “C", "D" e "E", constatou-se que os Ministros Ayres Britto, Ricardo Lewandowski, Gilmar Mendes, Joaquim Barbosa e Celso de Mello votaram de modo incoerente em casos parecidos.

A mesma ocorrência se verifica no "Quadro 04", em que foram analisados 4 (quatro) habeas corpus ( $\mathrm{HC} \mathrm{n}^{\circ} 106.510 / \mathrm{MG}, \mathrm{HC} \mathrm{n}^{\circ} 108.872 / \mathrm{RS}, \mathrm{HC} \mathrm{n}^{\circ}$ 114.060/MG, HC no 113.782/RS) apelidados de decisões "F", "G", "H" e "I". Notou-se que os Ministros Ayres Britto e Joaquim Barbosa proferiram decisões diferentes no julgamento de casos parecidos.

Por mais que haja uma ampla doutrina que defenda o uso dos precedentes como vinculativos (obrigatórios), a pesquisa se concentra na defesa dos precedentes horizontais, mais especificamente no autoprecedente, que se refere à obrigação de um juiz ou ministro seguir o precedente que foi adotado por ele próprio em um caso parecido anterior.

Sustenta-se o autoprecedente a partir dos casos selecionados, com base na coerência, segurança jurídica, estabilidade, previsibilidade das decisões, despersonalização das demandas, consistência, replicabilidade e necessidade de legislar, uma vez que nos casos selecionados não houve a ocorrência de overruling, overriding, distinguishing ou transformation.

A pesquisa constatou que:

a) há ministros que votam de forma incoerente em casos parecidos;

b) em grande parte dos julgamentos há "meros votos de acompanhamento" em que o relator profere seu voto e os demais votos são apenas registrados em ata;

c) afirmações pelos ministros de que naquele caso há precedentes e 
jurisprudência que solucionam a questão;

d) a argumentação do voto, muitas vezes, se baseia em acórdãos da Primeira Turma;

e) os ministros fundamentam através de citações e transcrições de decisões de casos que não são parecidos com a questão que está sendo apreciada;

f) há carência de diálogo entre os ministros;

g) grande parte das ementas não traduzem de modo claro o caso;

h) quando a decisão apresenta uma roupagem de "monocrática", ou seja, quando há apenas a transcrição do voto do relator, a ementa se baseia apenas nos argumentos desse voto;

i) existem votos prolixos e eruditos;

j) o tema carece de uma jurisprudência genuína.

De todos os habeas corpus selecionados, há um importante apontamento do Ministro Gilmar Mendes na "Decisão H" (HC no 114.060/MG) que propõe uma maior atenção por parte do STF, juízes e tribunais, a fim de se obter um critério padrão de argumento. Além disso, considera que o Congresso Nacional e os meios acadêmicos poderiam avaliar o tema.

No julgamento da "Decisão $H$ " os demais ministros não levaram em consideração o argumento levantado por Gilmar Mendes. Sugere-se que nesse julgamento o relator poderia ter aplicado o Art. 22, parágrafo único, "a” do RISTF que propõe que o Relator leve a questão passível de controvérsia entre as turmas até o Plenário. Isso seria um grande passo, pois não há decisão do Plenário sobre essa matéria até o presente momento.

Pontua-se que de todas as decisões analisadas, houve recurso para o Superior Tribunal de Justiça. Em cada um dos casos, o Superior Tribunal de Justiça entendeu que a reincidência deve ensejar uma maior rigidez na penalização da conduta, uma vez que o paciente demonstra uma propensão à criminalidade (leia-se: reincidente). Ainda que o estudo tenha contemplado o exame de autoprecedentes do Supremo e a defesa de que os mesmos sejam respeitados em casos parecidos, visualiza-se que uma maior atenção aos precedentes do STJ e também da Primeira Turma do STF seria um caminho para a resolução dessa 
questão.

Conclui-se que no caso analisado não há jurisprudência sobre o assunto. De modo algum objetiva-se dizer que o Supremo não possui jurisprudência sobre outros temas, pois uma afirmativa como essa é imprudente. No caso em análise, identifica-se a existência de jurisprudência e precedentes da Primeira Turma do STF, ao passo que a Segunda Turma possuiria tão somente decisões judiciais sobre o tema.

Propõe-se com a pesquisa a demonstração de que o desrespeito ao autoprecedente pode gerar situações conflituosas e incoerentes no julgamento de casos parecidos. Além disso, sustenta-se que os autoprecedentes devem ser respeitados, especialmente quando a liberdade de locomoção, um dos principais direitos fundamentais inerente ao indivíduo, está em risco. 


\section{Referências bibliográficas}

ALEXANDER, Larry. "Constrained by Precedent," 63 Southern California Law Review 1, 1989.

AMAYA, AMALIA. Legal Justification by Optimal Coherence. (Setembro de 2011). Ratio Juris, Vol. 24, Issue 3, pp. 304-329, 2011. Disponível em: $<$ http://papers.ssrn.com/sol3/papers.cfm?abstract_id=1908015>. Acesso em: 12 dez. 2013.

ANNENBERG, Flávia. “A Posição do STF nos Casos da Pesquisa com CélulasTronco Embrionárias e da Interrupção da Gravidez do Feto Anencéfalo - Existe Relação de Precedentes entre eles?”, in Jurisdição Constitucional no Brasil. São Paulo: Malheiros, 2012.

BARROSO, Luís Roberto. Mudança da Jurisprudência do Supremo Tribunal Federal em Matéria Tributária. Segurança Jurídica e Modulação dos Efeitos $\begin{array}{llll}\text { Temporais das Decisões } & \text { Judiciais. } & \text { Disponível }\end{array}$ em: $<$ http://www.luisrobertobarroso.com.br/wpcontent/themes/LRB/pdf/parecer mudanca_da_jurisprudencia_do_stf.pdf $>$. Acessado em: 05 de mar. 2013.

BINENBOJM, Gustavo. Crítica às Sessões do STF é Injusta. Disponível em: $<$ http://www.conjur.com.br/2009-mai-02/construcao-institucional-judiciario-foipotencializado-tv-justica>. Acessado em: 02 out. 2012.

BITENCOURT, Cezar Roberto. Tratado de Direito Penal. $15^{\text {a }}$ edição. São Paulo: Ed. Saraiva, 2010.

BUSTAMANTE, Thomas da Rosa de. Uma Teoria Normativa do Precedente 
Judicial - o Peso da Jurisprudência na Argumentação Jurídica. Tese (Doutorado em Direito), Faculdade de Direito da Pontifícia Universidade Católica do Rio de Janeiro, 2007.

COMELLA, Víctor Ferreres. Una Defensa del Modelo Europeu de Control de Constitucionalidad. Madrid: Marcial Pons, 2011.

COSTA, Natália Lopes. "Medidas Utilizadas Pelo STF para Acelerar um Julgamento Político - Algumas Mudanças Introduzidas pela Corte no "Caso do Mensalão", in Jurisdição Constitucional no Brasil. São Paulo: Malheiros, 2012.

DIDIER Jr., Fredie; BRAGA, Paula Sarno; OLIVEIRA, Rafael. Curso de Direito Processual Civil. Vol. II. 8a ed. Salvador: JusPodivm, 2013.

DUXBURY, Neil. The Nature and Authority of Precedent. New York: Cambridge University Presss, 1991.

DWORKIN, Ronald. Law's Empire. Trad. Gildo Rios, O Império do Direito, São Paulo: Martins Fontes, 1999.

EDUARDO, Victor; GONÇALVES, Rios. Direito Penal Esquematizado- Parte Especial. São Paulo: Ed. Saraiva, 2011.

ESTEFAM, André; Gonçalves, Victor Eduardo Rios Gonçalves. Direito Penal Esquematizado- Parte Geral. São Paulo: Ed. Saraiva, 2012.

FALCÃO, Joaquim. Cerdeira, Pablo de Camargo. Arguelhes, Diego Werneck. I Relatório Supremo em Números: O Múltiplo Supremo. Rio de Janeiro, FGV, 2011.

GARCIA, José Carlos. O Coro no Conselho dos Éforos. Tese (Doutorado em Direito), Faculdade de Direito da Pontifícia Universidade Católica do Rio de Janeiro, 2011.

GERHARDT, Michael J. The Power of Precedent. New York: Oxford University Press, 2008.

GRECO, Rogério. Curso de Direito Penal- Parte Geral. Volume I. $13^{\mathrm{a}}$ edição. 
Rio de Janeiro: Impetus, 2011.

KLAFKE, Guilherme Forma. Vícios no Processo Decisório do Supremo Tribunal Federal. Monografia apresentada à Escola de Formação da Sociedade Brasileira de Direito Público- SBDP, 2010.

KLAFKE, Guilherme Forma; PRETZEL, Bruna Romano. Processo Decisório no Supremo Tribunal Federal: Aprofundando o Diagnóstico das Onze Ilhas. Revistas de Estudos Empíricos em Direito. Vol. 1, n 1, jan 2013, p. 83-104.

LAMOND, Grant, "Precedent and Analogy in Legal Reasoning", The Stanford Encyclopedia of Philosophy (Fall 2008 Edition), Edward N. Zalta (ed.). Disponível em: <http://plato.stanford.edu/archives/fall2008/entries/legal-reasprec/>. Acesso em: 02 de set. de 2013.

LÓPEZ MEDINA, Diego Eduardo; GORDILLO, Roberto. "Consideraciones Ulteriores sobre el Análisis Estático de Jurisprudencia”, in Revista de Derecho Público, n. 15, 2002, p. 3-47.

MacCormick, Neil. Legal Reasoning and Legal Theory, Oxford: Oxford University Press, 1978.

MacCORMICK, Neil e SUMMERS, Robert S. Interpreting Precedents. Precedent in Law. Oxford: Oxford University Press, 1997.

MARINONI, Luiz Guilherme. “Aproximação Crítica entre as Jurisdições de Civil Law e de Common Law e a Necessidade de Respeito aos Precedentes no Brasil", in Revista da Faculdade de Direito da UFPR, Curitiba, 2009, p. 11-58. , Luiz Guilherme. Precedentes Obrigatórios. São Paulo: Ed. Revista dos Tribunais, 2010.

MARSHALL, Geoffrey. What is Binding in a Precedent. In: MacCormick, Neil; SUMMERS, Robert S. Interpreting Precedents: a Comparative Study. London: Darmouth, 1997, p. 500 e ss.

MELlO, Patrícia Perrone Campos. Precedentes: o Desenvolvimento Judicial do Direito no Constitucionalismo Contemporâneo. Rio de Janeiro: Renovar, 2008. 
MENDES, Conrado Hübner. Controle de Constitucionalidade e Democracia. Rio de Janeiro: Elsevier, 2008.

(2010a). Onze Ilhas. Disponível em:

$<$ http://www.osconstitucionalistas.com.br/onze-ilhas $>$. Acesso em: 02 out. 2012.

(2011a) . Sessão de Leitura no STF. Disponível em: $<$ http://www1.folha.uol.com.br/fsp/opiniao/fz0510201007.htm>. Acesso em: 02 out. 2012.

(2011a). Direitos Fundamentais, Separação de Poderes e Deliberação. São Paulo: Saraiva, 2011.

. O projeto de uma Corte Deliberativa, in Jurisdição Constitucional no Brasil. São Paulo: Malheiros, 2012.

Constitutional Courts and Deliberative Democracy. Oxford Constitutional Theory. Oxford: Oxford University Press, 2013.

NADER, Paulo. Introdução ao Estudo do Direito. São Paulo: Ed. Forense. 13a edição, 1996. P. 199-209.

PONCE, Carolina Ignácio. "Definição de Pauta no Controle de Constitucionalidade de Emendas Constitucionais nos Governos FHC e Lula", in Jurisdição Constitucional no Brasil. São Paulo: Malheiros, 2012.

REALE, Miguel. Lições Preliminares de Direito. $27^{\mathrm{a}}$ edição. São Paulo: Saraiva, 2005. Pg. 167 a 175.

RODRIGUEZ, José Rodrigo. Como Decidem as Cortes? Para uma Crítica do Direito (Brasileiro). Rio de Janeiro: Ed. FGV, 2013.

RODRIGUEZ, José Rodrigo; Püschel, Flavia Portella; Machado, Marta Rodriguez de Assis. O Raciocínio Jurídico- Dogmático e suas Relações com o Funcionamento do Poder Judiciário e a Democracia, in Revista Direito GV, $\mathrm{n}^{\circ} 11$, novembro de 2007.

SALIM, Alexandre; AZEVEDO, Marcelo André de. Direito Penal- Parte Geral.

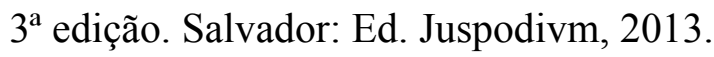


SCHAUER, Frederick. Precedent. Stanford Law Review, February, 1987. . Frederick. Thinking Like a Lawyer. Cambridge: Harvard University Press, 2009.

SILVA, Celso de Albuquerque. Do Efeito Vinculante- sua Legitimação e Aplicação. Rio de Janeiro: Lumen Juris, 2005.

SILVA, Virgílio Afonso da, e MENDES, Conrado Hübner (2009). "Entre a Transparência e o Populismo Judicial”. Folha de S. Paulo 11.5.2009, p. 3.

SILVA, Virgílio Afonso da. "O STF e o controle de constitucionalidade: deliberação, diálogo e razão pública", in Revista de Direito Administrativo n ${ }^{\circ}$ 250, 2009, p. 197-227.

SOLUM, Lawrence B., Virtue Jurisprudence: A Virtue-Centered Theory of Judging. Metaphilosophy, Vol. 34, No. 1/2, pp. 178-213, January 2003. Disponível em: $\quad<$ http://ssrn.com/abstract $=369940 \quad$ or http://dx.doi.org/10.2139/ssrn.369940>. Acesso em: 01 jan. 2014.

SOUZA, Marcelo Alvez dias de. Do Precedente Judicial à Súmula Vinculante. Curitiba: Juruá, 2007.

STRUCHINER, Noel. Uma Análise da Textura Aberta da Linguagem e sua Aplicação ao Direito. Dissertação de Mestrado. Departamento de Filosofia da Pontifícia Universidade Católica do Rio de Janeiro, Fevereiro de 2001.

SUNDFELD, Carlos Ari; Pinto, Henrique Motta. Três desafios para melhorar a jurisdição constitucional brasileira, in Jurisdição Constitucional no Brasil. São Paulo: Malheiros, 2012.

SUNDFELD, Carlos Ari; Souza, Rodrigo Pagani. Accountability e Jurisprudência do STF: Estudo Empírico de Variáveis Institucionais e Estrutura das Decisões, in Jurisdição Constitucional no Brasil. São Paulo: Malheiros, 2012.

TUCCI, José Rogério Cruz e. Precedente Judicial como Fonte do Direito. São Paulo: Revista dos Tribunais, 2004. 
VERÍSSIMO, Marcos Paulo. “A Constituição de 1988, Vinte Anos Depois: Suprema Corte e Ativismo Judicial “à Brasileira”, in Revista Direito GV, jul- dez 2008, p. 407 a 440.

VOJVODIC, Adriana de Moraes. Precedentes e Argumentação no Supremo Tribunal Federal: Entre a Vinculação ao Passado e a Sinalização para o Futuro. Tese (Doutorado em Direito), Faculdade de Direito da Universidade de São Paulo, 2012.

VOJVODIC, Adriana, Cardoso, Evorah; Machado, Ana. "Escrevendo um Romance, Primeiro Capítulo: Precedentes e Processo Decisório no STF", in Revista Direito GV, $\mathrm{n}^{\mathrm{o}}$ 9, 2009, p. 21-44. Disponível em: http://www.scielo.br/scielo.php?pid=S1808-24322009000100002\&script=sci artt ext. Acesso em: 05 jan de 2013.

VOJVODIC, Adriana, Cardoso, Evorah; Machado, Ana. Machado, Ana Mara França. Precedentes e Processo Decisório em uma Corte Suprema: uma Análise do Caso Brasileiro. ANPOCS, outubro/2008.

WAMBIER, Teresa Arruda Alvim. Controle das Decisões Judiciais por Meio de Recursos de Estrito Direito e de Ação Rescisória - Recurso Extraordinário, Recurso Especial e Ação Rescisória: O que é uma Decisão Contrária à Lei? São Paulo: Revista dos Tribunais, 2001.

ZAFFARONI, Eugênio Raul e Pierangeli, José Henrique Da Tentativa: Doutrina e Jurisprudência, $6^{\circ}$ edição, Editora RT, 2000. 


\section{8}

Sites Webs apresentados

http://www.sbdp.org.br/ Acesso em: 04.08.2013

http://www.stf.jus.br/portal/principal/principal.asp Acesso em: 02.10.2013

http://www.stj.jus.br/portal stj/publicacao/engine.wsp Acesso em: 05.10.2013

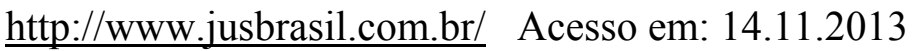

http://pt.wikipedia.org/wiki/Ginger_ale Acesso em: 20 jun. 2013

http://www.istoe.com.br/reportagens/3144_O+BRASIL+DAS+181+MIL+LEIS Acesso em: 04.02.2014 
Anexos

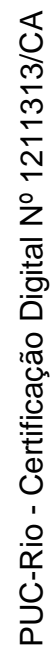




\section{Quadro 01- Decisões furto simples consumado da Primeira Turma do STF}

\begin{tabular}{|c|c|c|c|c|c|c|c|c|c|}
\hline \multirow[t]{2}{*}{ MINISTRO } & \multicolumn{9}{|c|}{$\begin{array}{l}\text { QUADRO 01- POSSIBILIDADE DE APLICAÇÃO OU NÃO DO PRINCÍPIO DA INSIGNIFICÂNCIA A RÉUS REINCIDENTES EM CASOS DE FURTO SIMPLES CONSUMADO- 1ª TURMa } \\
\text { do STF }\end{array}$} \\
\hline & $\begin{array}{c}\mathrm{HC} \mathrm{n} \mathbf{n}^{\circ} \\
101.998 / \mathrm{MG}\end{array}$ & HC n $n^{0}$ 98.917/RS & $\mathrm{HC} \mathrm{n}^{\circ} 109.739 / \mathrm{SP}$ & HC no 108.969/MG & HC no 111.394/MG & HC no 112.319/RS & HC n $n^{0} 110.926 / M G$ & HC no 111.611/MG & HC no 120.043/DF \\
\hline $\begin{array}{l}\text { Cármen } \\
\text { Lúcia }\end{array}$ & Não se aplica & Não se aplica & $\begin{array}{c}\text { Não se aplica } \\
\text { (RELATORA) } \\
*\end{array}$ & Não se aplica & $\begin{array}{c}\text { Não se aplica } \\
\text { (RELATORA) } \\
*\end{array}$ & $\begin{array}{c}\text { Não participou } \\
\text { justificadamente }\end{array}$ & $\begin{array}{c}\text { Não participou } \\
\text { justificadamente }\end{array}$ & Não se aplica & \\
\hline $\begin{array}{c}\text { Ricardo } \\
\text { Lewandowski }\end{array}$ & Não se aplica & Não se aplica & & & & & & & \\
\hline Dias Toffoli & $\begin{array}{c}\text { Não se aplica } \\
\text { (RELATOR) } \\
*\end{array}$ & $\begin{array}{c}\text { Não se aplica } \\
\text { (RELATOR) } \\
*\end{array}$ & Não se aplica & Não se aplica & $\begin{array}{c}\text { Não se aplica } \\
*\end{array}$ & $\begin{array}{c}\text { Não se aplica } \\
\text { (RELATOR) } \\
*\end{array}$ & $\begin{array}{c}\text { Não se aplica } \\
\text { (RELATOR) } \\
*\end{array}$ & $\begin{array}{c}\text { Não se aplica } \\
*\end{array}$ & Não se aplica \\
\hline $\begin{array}{c}\text { Luís Roberto } \\
\text { Barroso }\end{array}$ & & & & & & & & & Não se aplica \\
\hline Luiz Fux & & & Não se aplica & $\begin{array}{c}\text { Não se aplica } \\
\text { (RELATOR) } \\
*\end{array}$ & $\begin{array}{c}\text { Não se aplica } \\
*\end{array}$ & $\begin{array}{c}\text { Não se aplica } \\
*\end{array}$ & $\begin{array}{c}\text { Não se aplica } \\
*\end{array}$ & $\begin{array}{c}\text { Não se aplica } \\
\text { (RELATOR) } \\
*\end{array}$ & $\begin{array}{c}\text { Não se aplica } \\
\text { (RELATOR) } \\
*\end{array}$ \\
\hline $\begin{array}{c}\text { Marco } \\
\text { Aurélio de } \\
\text { Mello }\end{array}$ & Não se aplica & Não se aplica & Não se aplica & Não se aplica & $\begin{array}{c}\text { Não se aplica } \\
*\end{array}$ & $\begin{array}{c}\text { Não se aplica } \\
*\end{array}$ & $\begin{array}{c}\text { Não se aplica } \\
*\end{array}$ & $\begin{array}{c}\text { Não se aplica } \\
*\end{array}$ & $\begin{array}{l}\text { Não participou } \\
\text { justificadamente }\end{array}$ \\
\hline $\begin{array}{l}\text { Rosa Maria } \\
\text { Weber }\end{array}$ & & & & Não se aplica & Aplica-se & $\begin{array}{c}\text { Aplica-se } \\
*\end{array}$ & $\begin{array}{c}\text { Aplica-se } \\
*\end{array}$ & Aplica-se & Não se aplica \\
\hline
\end{tabular}




\begin{tabular}{|c|c|c|c|c|c|c|c|c|}
\hline $\begin{array}{l}\text { Decisão unânime } \\
\text { no sentido da } \\
\text { denegação } \\
\text { ordem }\end{array}$ & \begin{tabular}{|lr} 
Decisão unânime \\
no sentido da \\
denegação & da \\
ordem &
\end{tabular} & $\begin{array}{l}\text { Decisão unânime no } \\
\text { sentido da } \\
\text { denegação da ordem }\end{array}$ & $\begin{array}{l}\text { Decisão unânime no } \\
\text { sentido da denegação } \\
\text { da ordem }\end{array}$ & $\begin{array}{l}\text { Por maioria de votos, } \\
\text { denegou-se a ordem }\end{array}$ & $\begin{array}{l}\text { Por maioria de votos, } \\
\text { denegou-se a ordem }\end{array}$ & $\begin{array}{l}\text { Por maioria de votos, } \\
\text { denegou-se a ordem }\end{array}$ & $\begin{array}{l}\text { Por maioria de votos, } \\
\text { denegou-se a ordem }\end{array}$ & $\begin{array}{l}\text { Decisão unânime no } \\
\text { sentido da denegação } \\
\text { da ordem }\end{array}$ \\
\hline $\begin{array}{l}\text { Julgamento: } \\
23.11 .2010 \\
\text { Dje: } 22.03 .2011\end{array}$ & \begin{tabular}{|l} 
Julgamento: \\
22.02 .2011 \\
Dje: 16.05 .2011
\end{tabular} & \begin{tabular}{|l|} 
Julgamento: \\
13.12 .2011 \\
Dje: 14.02 .2012
\end{tabular} & \begin{tabular}{|l} 
Julgamento: \\
14.02 .2012 \\
Dje: 07.03 .2012
\end{tabular} & $\begin{array}{l}\text { Julgamento: } \\
24.04 .2012 \\
\text { Dje: } 16.10 .2013\end{array}$ & \begin{tabular}{|l} 
Julgamento: \\
20.03 .2012 \\
Dje: 25.04 .2012
\end{tabular} & \begin{tabular}{|l} 
Julgamento: \\
20.03 .2012 \\
Dje: 25.04 .2012
\end{tabular} & \begin{tabular}{|l} 
Julgamento: \\
08.05 .2012 \\
Dje: 15.06 .2012
\end{tabular} & \begin{tabular}{|l} 
Julgamento: \\
19.11.2013 \\
Dje: 03.12 .2013
\end{tabular} \\
\hline $\begin{array}{l}\text { Caso: } \text { furto simples } \\
\text { de } 9 \text { (nove) barras } \\
\text { de } r \text { chocolates } \\
\text { calculadas em R\$ } \\
45,00 \text { (quarenta e } \\
\text { cinco reais). }\end{array}$ & $\begin{array}{llr}\text { Caso: } & \text { furto } \\
\text { simples } & \text { de } & \text { uma } \\
\text { bicicleta } & \text { de } \\
\text { avaliada } & \text { em } & \text { R } \$ \\
180,00 & \text { (cento } & \text { e } \\
\text { oitenta } & \text { reais). }\end{array}$ & $\begin{array}{l}\text { Caso: furto simples } \\
\text { de um chuveiro e } 30 \\
\text { (trinta) metros de fio } \\
\text { de cobre de um } \\
\text { estabelecimento } \\
\text { comercial avaliados } \\
\text { em } R \$ 110,00 \text { (cento } \\
\text { e dez reais). }\end{array}$ & $\begin{array}{l}\text { Caso: furto simples de } \\
\text { um relógio de R\$ } \\
50,00 \quad \text { (cinquenta } \\
\text { reais). }\end{array}$ & $\begin{array}{l}\text { Caso: furto simples de } \\
\text { um celular avaliado } \\
\text { em R } \$ 60,00 \text { (sessenta } \\
\text { reais). }\end{array}$ & $\begin{array}{l}\text { Caso: furto simples } \\
\text { de uma bicicleta } \\
\text { calculada em R\$ } \\
100,00 \text { (cem reais). }\end{array}$ & 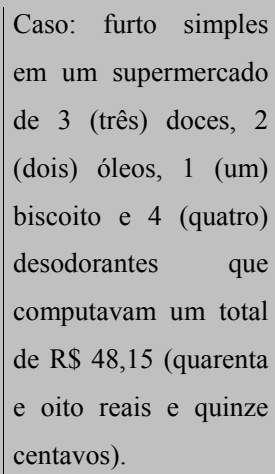 & $\begin{array}{l}\text { Caso: furto simples de } \\
\text { um celular avaliado } \\
\text { em R\$ } 150,00 \text { (cento } \\
\text { e cinquenta reais). }\end{array}$ & $\begin{array}{l}\text { Caso: furto simples } \\
\text { de um porta-moedas } \\
\text { contendo R\$ } 30,00 \\
\text { (trinta reais) } \\
\text { cartão um } \\
\text { transporte. }\end{array}$ \\
\hline
\end{tabular}

Quadro 01- Decisões furto simples consumado da Primeira Turma do STF

* Inteiro teor que apresenta a transcrição integral do voto do Ministro em referência. 


\section{Quadro 02- Decisões furto simples tentado da Primeira Turma do STF}

\begin{tabular}{|c|c|c|c|c|c|}
\hline \multirow{2}{*}{ MINISTRO } & \multicolumn{5}{|c|}{$\begin{array}{l}\text { QUADRO 02- POSSIBILIDADE DE APLICAÇÃO OU NÃO DO PRINCÍPIO DA INSIGNIFICÂNCIA A RÉUS REINCIDENTES EM CASOS DE FURTO SIMPLES } \\
\text { TENTADO- } 1^{\text {a }} \text { Turma do STF }\end{array}$} \\
\hline & HC no 101.591/MG & HC $n^{0} 101.906 / M G$ & HC no $107.674 / M G$ & HC no 111.124/RS & HC no $108.403 / R S$ \\
\hline Cármen Lúcia & $\begin{array}{l}\text { Não se aplica } \\
*\end{array}$ & Não se aplica & $\begin{array}{c}\text { Não se aplica } \\
\text { (RELATORA) } \\
*\end{array}$ & $\begin{array}{l}\text { Não participou } \\
\text { justificadamente }\end{array}$ & \\
\hline $\begin{array}{l}\text { Ricardo } \\
\text { Lewandowski }\end{array}$ & $\begin{array}{c}\text { Não se aplica } \\
*\end{array}$ & Não se aplica & & & \\
\hline Dias Toffoli & $\begin{array}{c}\text { Não se aplica } \\
\text { (RELATOR) } \\
*\end{array}$ & $\begin{array}{c}\text { Não se aplica } \\
\text { (RELATOR) } \\
*\end{array}$ & Não se aplica & $\begin{array}{c}\text { Aplica-se } \\
\text { (RELATOR) } \\
*\end{array}$ & $\begin{array}{c}\text { Não se aplica } \\
*\end{array}$ \\
\hline Luiz Fux & & & Não participou justificadamente & Não se aplica & $\begin{array}{c}\text { Não se aplica } \\
\text { (RELATOR) } \\
*\end{array}$ \\
\hline
\end{tabular}




\begin{tabular}{|c|c|c|c|c|c|}
\hline $\begin{array}{c}\text { Marco Aurélio } \\
\text { de Mello }\end{array}$ & $\begin{array}{c}\text { Aplica-se } \\
*\end{array}$ & $\begin{array}{c}\text { Aplica-se } \\
*\end{array}$ & Não se aplica & Não se aplica & $\begin{array}{c}\text { Não se aplica } \\
*\end{array}$ \\
\hline \multirow[t]{4}{*}{$\begin{array}{l}\text { Rosa Maria } \\
\text { Weber }\end{array}$} & & & & Aplica-se & $\begin{array}{c}\text { Aplica-se } \\
*\end{array}$ \\
\hline & $\begin{array}{l}\text { Por maioria de votos, denegou-se a } \\
\text { ordem }\end{array}$ & $\begin{array}{l}\text { Decisão unânime no sentido da } \\
\text { denegação da ordem }\end{array}$ & $\begin{array}{l}\text { Decisão unânime no sentido da } \\
\text { denegação da ordem }\end{array}$ & $\begin{array}{l}\text { Por maioria de votos, } \\
\text { denegou-se a ordem }\end{array}$ & $\begin{array}{l}\text { Por maioria de votos, denegou- } \\
\text { se a ordem }\end{array}$ \\
\hline & $\begin{array}{l}\text { Julgamento: } 22.02 .2011 \\
\text { Dje: } 04.05 .2011\end{array}$ & $\begin{array}{l}\text { Julgamento: } 22.02 .2011 \\
\text { Dje: } 16.05 .2011\end{array}$ & $\begin{array}{l}\text { Julgamento: } 30.08 .2011 \\
\text { DJe: } 14.09 .2011\end{array}$ & $\begin{array}{l}\text { Julgamento: } 29.05 .2012 \\
\text { Dje: } 21.08 .2012\end{array}$ & $\begin{array}{l}\text { Julgamento: } 05.02 .2013 \\
\text { DJe: } 18.03 .2013\end{array}$ \\
\hline & $\begin{array}{l}\text { Caso: furto tentado de um secador } \\
\text { avaliado em } \mathrm{R} \$ 40,00 \text { (quarenta } \\
\text { reais). }\end{array}$ & 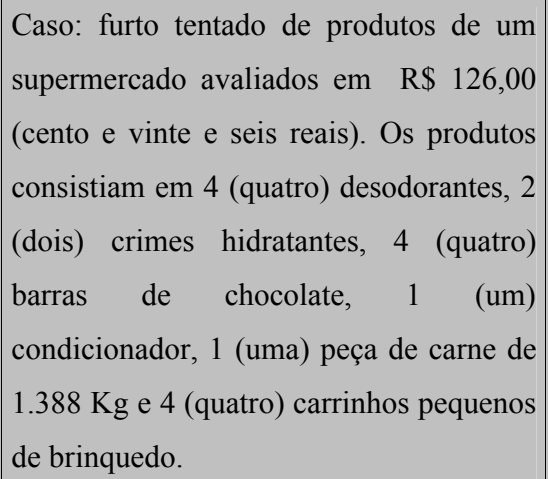 & $\begin{array}{l}\text { Caso: furto tentado de } 5 \text { (cinco) } \\
\text { barras de chocolate avaliadas em } \\
\text { R\$ } 19,95 \text { (dezenove reais e } \\
\text { noventa e cinco centavos). }\end{array}$ & $\begin{array}{l}\text { Caso: furto tentado de } \\
\text { mercadorias avaliadas em R\$ } \\
139,80 \text { (cento e trinta e nove } \\
\text { reais e oitenta centavos) que } \\
\text { consistiam em } 6 \text { (seis) CD's e } \\
1 \text { (um) DVD. }\end{array}$ & $\begin{array}{l}\text { Caso: furto tentado de } 1 \text { (uma) } \\
\text { bolsa contendo documentos, } \\
\text { cartões de crédito, } 1 \text { (um } \\
\text { celular) e R } \$ 50,00 \text { (cinquenta } \\
\text { reais). }\end{array}$ \\
\hline
\end{tabular}

* Inteiro teor que apresenta a transcrição integral do voto do Ministro em referência. 


\section{Quadro 03- Decisões furto simples consumado da Segunda Turma do STF}

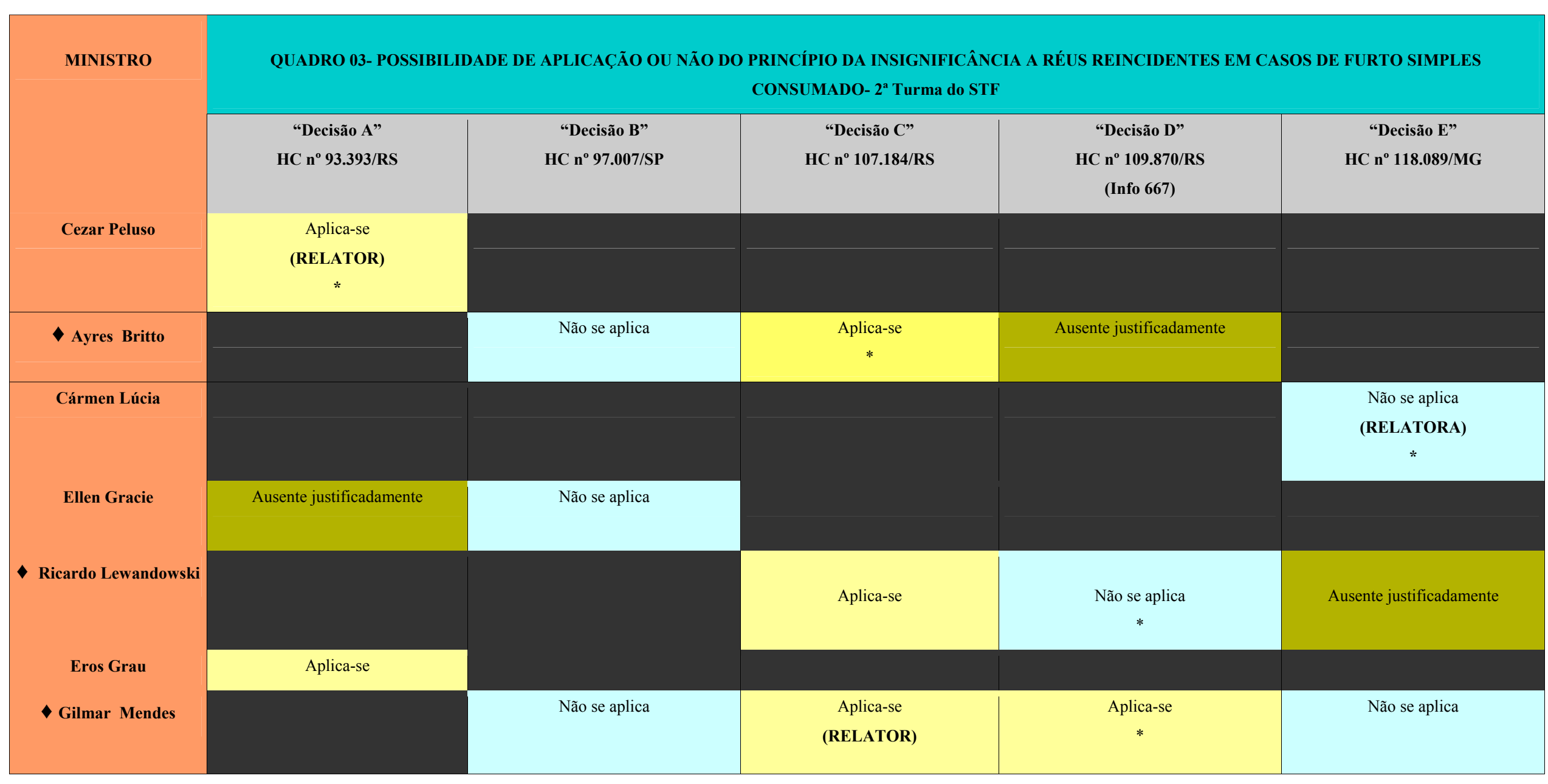




\begin{tabular}{|c|c|c|c|c|c|}
\hline \multirow[b]{2}{*}{$\checkmark$ Joaquim Barbosa } & & & * & & \\
\hline & Aplica-se & $\begin{array}{c}\text { Não se aplica } \\
\text { (RELATOR) } \\
*\end{array}$ & Ausente justificadamente & $\begin{array}{c}\text { Não se aplica } \\
\text { (RELATOR) } \\
*\end{array}$ & \\
\hline Celso de Mello & Aplica-se & Não se aplica & Aplica-se & Aplica-se & Ausente justificadamente \\
\hline \multirow[t]{4}{*}{ Teori Zavascki } & & & & & Não se aplica \\
\hline & $\begin{array}{c}\text { Decisão unânime pela concessão da } \\
\text { ordem. }\end{array}$ & $\begin{array}{l}\text { Decisão unânime pela denegação da } \\
\text { ordem. }\end{array}$ & $\begin{array}{l}\text { Decisão unânime pela concessão da } \\
\text { ordem. }\end{array}$ & $\begin{array}{l}\text { Houve empate, no entanto, foi } \\
\text { concedida a ordem (Art. 150, } \S 3^{\circ} \\
\text { RISTF) }\end{array}$ & $\begin{array}{l}\text { Decisão unânime pela denegação da } \\
\text { ordem. }\end{array}$ \\
\hline & $\begin{array}{l}\text { Julgamento: } 14.04 .2009 \\
\text { DJe:15.05.2009 }\end{array}$ & $\begin{array}{l}\text { Julgamento: } 01.02 .2011 \\
\text { DJe: } 31.03 .2011\end{array}$ & $\begin{array}{l}\text { Julgamento: } 18.10 .2011 \\
\text { DJe: } 21.11 .2011\end{array}$ & $\begin{array}{l}\text { Julgamento: 08.11.2011 } \\
\text { DJe: } 22.05 .2012\end{array}$ & $\begin{array}{l}\text { Julgamento: } 08.10 .2013 \\
\text { DJe: } 24.10 .2013\end{array}$ \\
\hline & $\begin{array}{l}\text { Caso: furto de roda com pneu R\$ } \\
160,00 \text { (art. } 155 \mathrm{c} / \mathrm{c} \text { art. } 14 \text {, II e } 61, \mathrm{I} \text {, } \\
\text { CP). }\end{array}$ & $\begin{array}{l}\text { Caso: furto de } \mathrm{R} \$ 5,00 \text { e documentos } \\
\text { pessoais da vítima (art. 155, CP). }\end{array}$ & $\begin{array}{l}\text { Caso: furto de R\$ 29,00- duas } \\
\text { gaiolas e } 4 \text { pássaros de espécies não } \\
\text { protegidas. (art. } 155, \mathrm{CP} \text { ) }\end{array}$ & $\begin{array}{l}\text { Caso: furto de R\$ 35,00 (Xampú e } \\
\text { Condicionador)- art. 155, CP. }\end{array}$ & $\begin{array}{l}\text { Caso: furto de } \mathrm{R} \$ 50,00 \text { e de um } \\
\text { maço de cigarros de } \mathrm{R} \$ 67,00 \text {. Art. } \\
155 \text {, CP. }\end{array}$ \\
\hline
\end{tabular}

Quadro 03- Decisões furto simples consumado da Segunda Turma do STF

* Inteiro teor que apresenta a transcrição integral do voto do Ministro em referência.

- Ministro que apresenta votos incoerentes ao compararmos votos proferidos em casos parecidos.

$243 \quad$ Art. $150, \S 3^{\circ}$ RISTF: "Nos habeas corpus e em matéria criminal, exceto o recurso extraordinário, havendo empate, prevalecerá a decisão mais favorável ao paciente ou réu." 


\section{Quadro 04- Decisões furto simples tentado da Segunda Turma do STF}

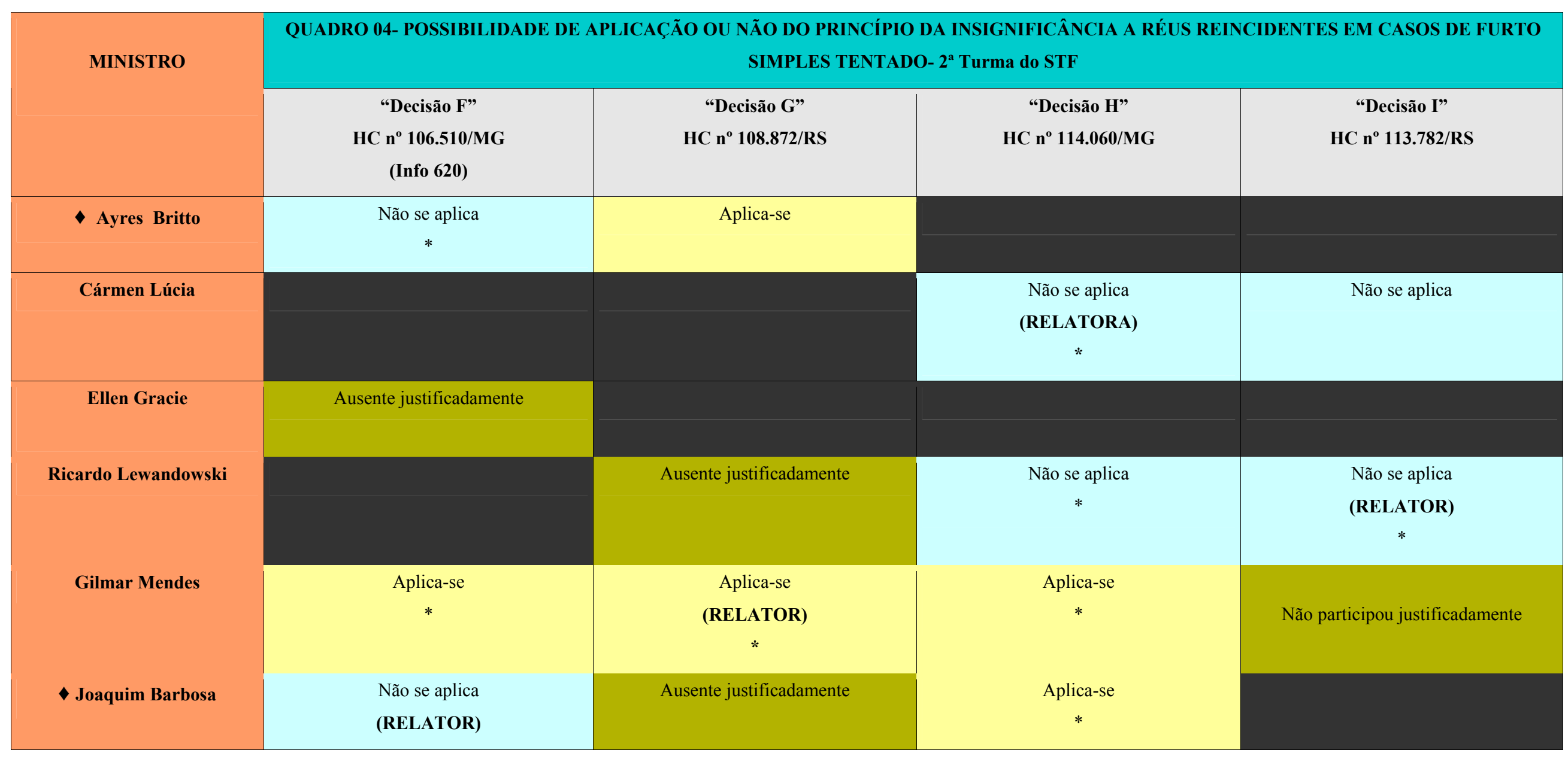




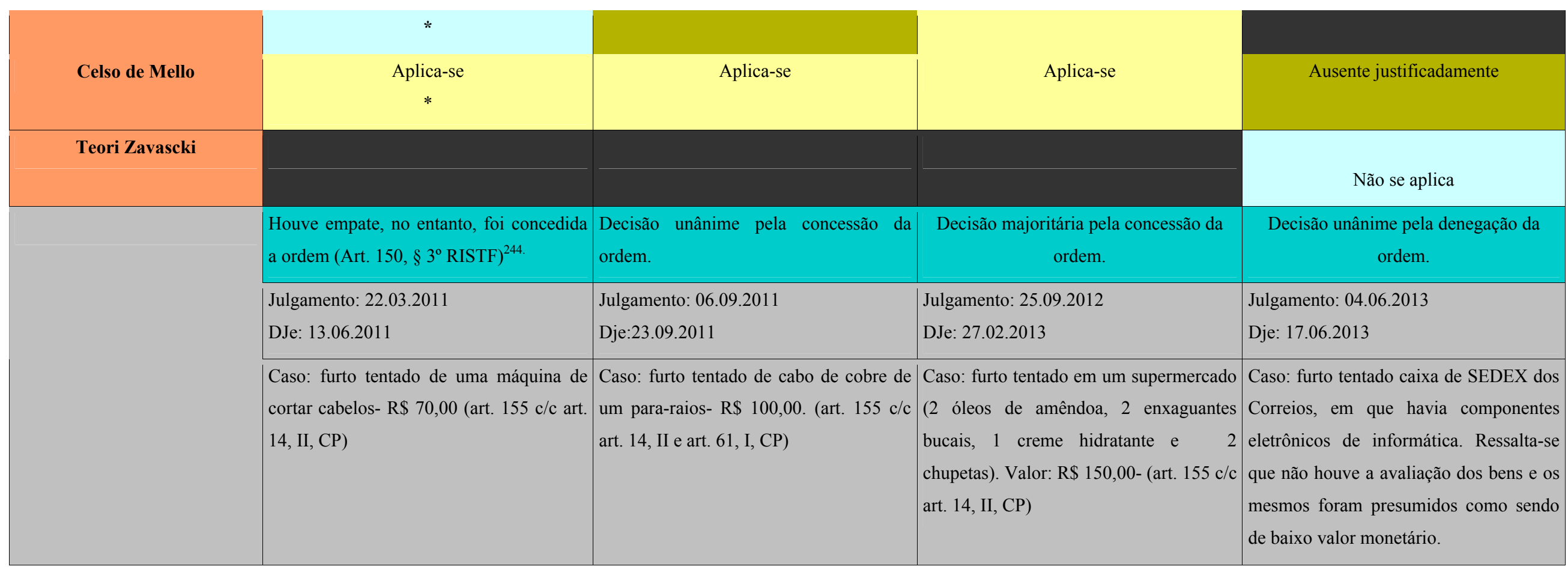

\section{Quadro 04- Decisões furto simples tentado da Segunda Turma do STF}

* Inteiro teor que apresenta a transcrição integral do voto do Ministro em referência.

- Ministro que apresentam votos incoerentes se compararmos o seu voto proferido em um outro caso parecido. 